http://kitaibelia.unideb.hu/

ISSN 2064-4507 (Online) • ISSN 1219-9672 (Print)

(C) Department of Botany, University of Debrecen, Hungary

22 (2): 317-357.; 2017

DOI: $10.17542 /$ kit.22.317

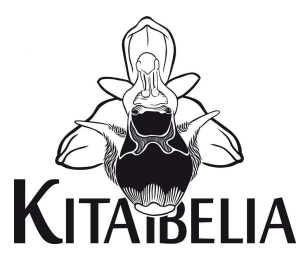

\title{
Florisztikai adatok a Tiszántúl középső részéről
}

\author{
LuKÁcs Balázs András ${ }^{*}$, GuLYÁs Gergely², HoRvÁTH Dénes², HőDÖR István², SCHMOTZER András³, \\ SRAMKó Gábor ${ }^{4,5}$, TAKÁCS Attilaa ${ }^{4,5}$, MolnÁr Attila ${ }^{6}$ \\ (1) MTA Ökológiai Kutatóközpont, DKI, Tisza-kutató Osztály, H-4026 Debrecen, Bem tér 18/C. \\ *lukacs.balazs@okologia.mta.hu \\ (2) BioAqua Pro Kft., H-4032 Debrecen, Soó R. u. 21. \\ (3) Bükki Nemzeti Park Igazgatóság, H-3304 Eger, Sánc u. 6. \\ (4) Debreceni Egyetem, Növénytani Tanszék, H-4032 Debrecen, Egyetem tér 1. \\ (5) MTA-DE “Lendület” Evolúciós Filogenomikai Kutatócsoport, H-4032 Debrecen, Egyetem tér 1. \\ (6) Debreceni Egyetem, Biológiai és Ökológiai Intézet, H-4032 Debrecen, Egyetem tér 1.
}

\section{Floristic data from the central part of the floristic region 'Crisicum' (E Hungary)}

\begin{abstract}
This paper reports new floristic data of 207 taxa. Data collected between 2005 and 2015; originated from the central part of the floristic region 'Crisicum' (i.e. the E part of the Great Hungarian Plain), which is a currently poorly studied area of Hungary from a floristic point of view. The paper reports occurrence localities for some rarities such as Asplenium trichomanes, Marsilea quadrifolia, Sisymbrium polymorphum, Viola stagnina, Gentiana pneumonanthe, Elymus elongatus, Montia fontana subsp. chondrosperma, Ranunculus rionii, Ranunculus illyricus, Myagrum perfoliatum, Sedum caespitosum, Vicia biennis, Dorycnium herbaceum, Oenanthe banatica, Peucedanum cervaria, Echium italicum, Digitalis lanata, Valerianella rimosa, Craex buekii, Cephalaria transsylvanica, Cyperus pannonicus.
\end{abstract}

Key-words: alien species, alkaline habitat, endangered species, Great Hungarian Plain, rare species

Összefoglalás - Cikkünkben összesen 207 taxon 2005 és 2015 között gyűjtött adatát összegezzük, amelyeket a Tiszántúli flórajárás (Crisicum) középső részén gyűjtöttünk. Az adatsorban a flórajárásra nézve számos ritka és veszélyeztetett faj is szerepel (pl. Asplenium trichomanes, Marsilea quadrifolia, Sisymbrium polymorphum, Viola stagnina, Gentiana pneumonanthe, Elymus elongatus, Montia fontana subsp. chondrosperma, Ranunculus rionii, Ranunculus illyricus, Myagrum perfoliatum, Sedum caespitosum, Vicia biennis, Dorycnium herbaceum, Oenanthe banatica, Peucedanum cervaria, Echium italicum, Digitalis lanata, Valerianella rimosa, Carex buekii, Cephalaria transsylvanica, Cyperus pannonicus).

Kulcsszavak: Alföld, idegenhonos fajok, ritka fajok, szikes élőhelyek, veszélyeztetett fajok

\section{Bevezetés}

A Crisicum területéről született flóramű (Soó \& MátHÉ 1938) és az azt kiegészítő közlemények (Soó 1940, 1948, Soó et al. 1942, UjvÁrosi 1940, 1941) megjelenése után az 1990-ig eltelt mintegy 40 évben a flórajárás középső és északi területeiről egyedül a Hortobágyi Nemzeti Park flóráját bemutató könyvfejezetet (SzujKó-LACZA et al. 1982) említhetjük, mint újabb összefoglalót. Ez a munka 768 virágos növényfaj és 6 páfrány adatait összegzi, a lefedett mintegy 64000 ha kiterjedésű terület irodalmi és herbáriumi feldolgozásával. Bár a 90- 
es évektől fellendülő florisztikai- és vegetációkutatások a Tiszántúl flórájának ismeretét is jelentősen szaporították, főképp a Dél-Tiszántúlról (amely értelmezésünkben a Nagy-Sárrét és Bihari-sík kistájaktól délre eső, de a Hármas-Körös-Hortobágy-Berettyó vonal és a Tisza közé be nem nyúló területeket jelenti a Crisicum-ban) keletkezett jelentős mennyiségű adat (JАKAB et al. 2000, ЈАКАВ \& TÓTH 2003, ЈАКАВ 2005, KAPOCSI et al. 1998, KERTÉSz 2000, PENKSZA \& KAPOCSI 1998, TóTH 2003). A Crisicum középső és északi részéről az újabb időszakban is csak szórványosan, alacsony számban jelentek meg florisztikai közlemények (lásd pl. MoLNÁR 1995, MOLNÁR 2005, LESKU \& MolnÁR 2007, TAKÁCS \& ZSÓLYOMI 2010, TAKÁCS et al. $2014 b$ ). Jelen közlemény részben ezek folytatásának tekinthető. Hiánypótlónak szánt közleményünkben a Crisicum középső és északi területein gyűjtött florisztikai adatainkat összegezzük. A vizsgált terület több kistájra kiterjed, ezeket MAROSI \& SOMOGYI (1990) felosztása szerint értelmezzük. Az érintett terület közigazgatási határok szerinti elhelyezkedését az 1. ábra mutatja.

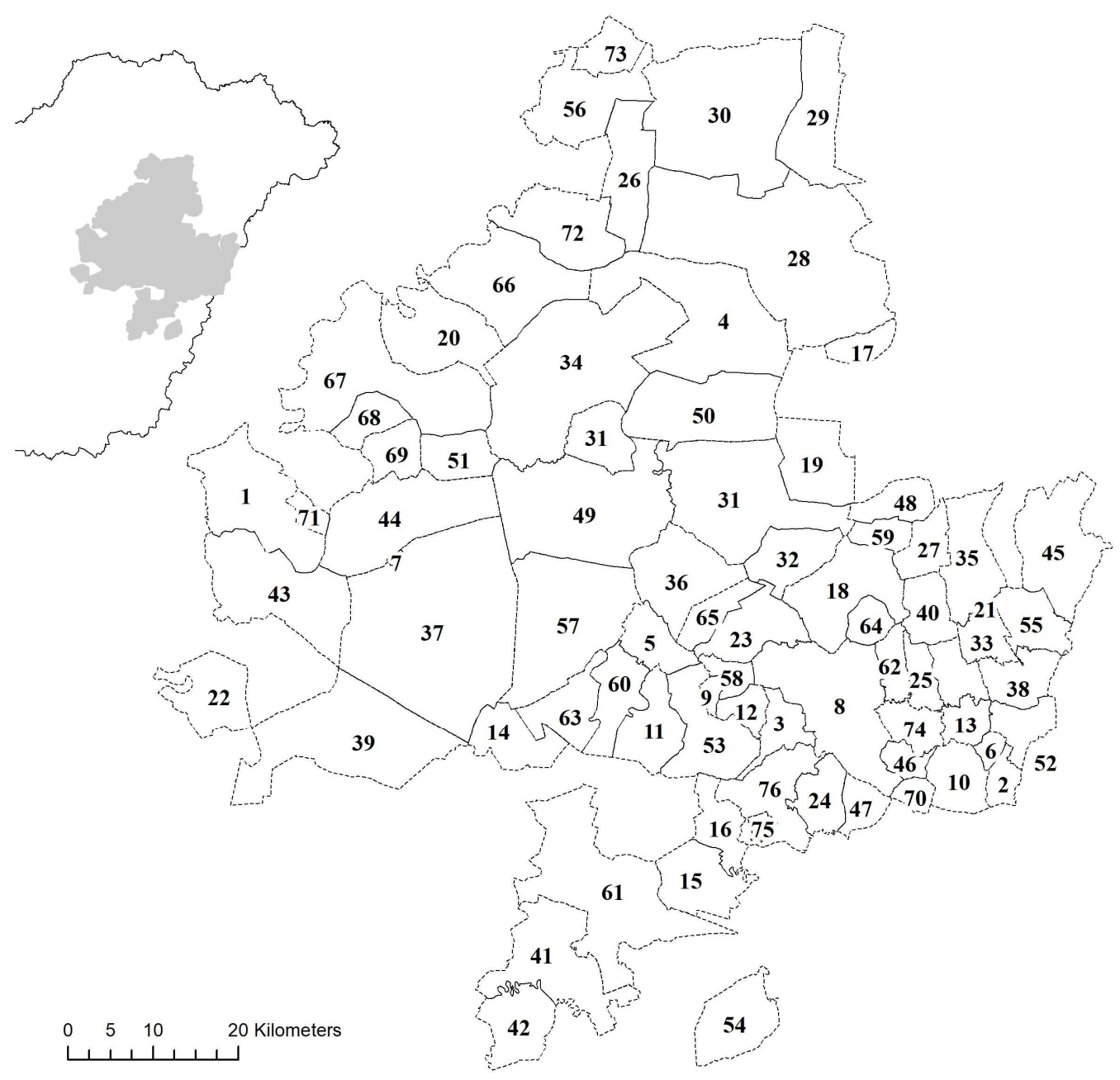

1. ábra. A vizsgált terület földrajzi elhelyezkedése és az adatokkal reprezentált községhatárok Fig. 1. The study area and the settlements represented by the dataset 
A térképen (1. ábra) sorszámmal jelölt települések:

\begin{tabular}{|c|c|c|c|}
\hline 1 - Abádszalók & 20 - Egyek & 39 - Kisújszállás & 58 - Sáp \\
\hline 2 - Ártánd & 21 - Esztár & 40 - Konyár & 59 - Sáránd \\
\hline 3 - Bakonszeg & 22 - Fegyvernek & 41 - Körösladány & 60 - Sárrétudvari \\
\hline 4 - Balmazújváros & 23 - Földes & 42 - Köröstarcsa & 61 - Szeghalom \\
\hline 5 - Báránd & 24 - Furta & 43 - Kunhegyes & 62 - Szentpéterszeg \\
\hline 6 - Bedő & 25 - Gáborján & 44 - Kunmadaras & 63 - Szerep \\
\hline 7 - Berekfürdő & 26 - Görbeháza & 45 - Létavértes & 64 - Tépe \\
\hline 8 - Berettyóújfalu & 27 - Hajdúbagos & 46 - Mezőpeterd & 65 - Tetétlen \\
\hline 9 - Bihardancsháza & 28 - Hajdúböszörmény & 47 - Mezősas & 66 - Tiszacsege \\
\hline 10 - Biharkeresztes & 29 - Hajdúdorog & 48 - Mikepércs & 67 - Tiszafüred \\
\hline 11 - Biharnagybajom & 30 - Hajdúnánás & 49 - Nádudvar & 68 - Tiszaigar \\
\hline 12 - Bihartorda & 31 - Hajdúszoboszló & 50 - Nagyhegyes & 69 - Tiszaörs \\
\hline 13 - Bojt & 32 - Hajdúszovát & 51 - Nagyiván & 70 - Told \\
\hline 14 - Bucsa & 33 - Hencida & 52 - Nagykereki & 71 - Tomajmonostora \\
\hline 15 - Csökmő & 34 - Hortobágy & 53 - Nagyrábé & 72 - Újszentmargita \\
\hline 16 - Darvas & 35 - Hosszúpályi & 54 - Okány & 73 - Újtikos \\
\hline 17 - Debrecen-Józsa & 36 - Kaba & 55 - Pocsaj & 74 - Váncsod \\
\hline 18 - Derecske & 37 - Karcag & 56 - Polgár & 75 - Vekerd \\
\hline 19 - Ebes & 38 - Kismarja & 57 - Püspökladány & 76 - Zsáka \\
\hline
\end{tabular}

Jelen közleményben a 2005 és 2015 között általunk gyűjtött értékesebb florisztikai adatokat összegezzük. Az adatokat községhatárok szerint közöljük, az egyes településekhez tartozó dűlőneveket az 1:10 000 méretarányú EOV rendszerű térképekről olvastuk le. Az enumerációba felvett hajtásos növények nevezéktana és sorszámozása KIRÁLY (2009) munkáját követi. A fajoknak az érintett területről ismert korábbi irodalmi és herbáriumi adatait hivatkozzuk. A herbáriumi anyagot a Debreceni Egyetem gyűjteményében vizsgáltuk (vö. TAKÁcS et al. 2014a, 2015). Az MTM Növénytár Carpatho-Pannonicum gyűjteményét azon fajok esetében ellenőriztük, amelyeknek nem találtuk irodalmi adatát és a Debreceni Egyetem gyűjteményében sem találtuk a vizgált területről származó példányát. A herbáriumi adatgyűjtés során a példányokat nem revideáltuk tematikusan, vagyis elfogadtuk a rajtuk feltüntetett taxonneveket. A Soó \& MÁTHÉ (1938) ill. SzUJKó-LACZA et al. (1982) által citált, általunk fel nem lelt herbáriumi lapokat irodalmi adatként, de a herbáriumi adatok között hivatkozzuk, a közigazgatási hovatartozás feltüntetésével. Nem citáljuk azokat a herbáriumi lapokat és irodalmi adatokat, amelyek a vizsgált községhatárokon belülről, de egyértelműen a Tiszántúl határán túlról, a Nyírség területérél származnak (Hajdúböszörmény, Debrecen, Mikepércs, Sáránd, Hajdúbagos, Hosszúpályi, Létavértes nyírségi külterülete). Az adatok között, az adatgyűjtő monogramja után feltüntetjük a lelőhelyeket lefedő flóratérképezési negyed-kvadrátok (NIKLFELD 1971) kódjait is. Mivel a vizsgált terület kutatottsága gyér, a fajok valódi tömegességi viszonyainak megítéléséhez nem rendelkezünk elég alapadattal. Az enumerációban szerepelnek olyan fajok, amelyek megítélésünk szerint egyértelműen „ritkák”, vagy „gyakoriak”, ezt jelezzük is, de sok faj esetében az adathiány, a teljes vizsgálati területre vonatkozó ismeretek hiánya miatt nem teszünk ilyen megállapítást. Olyan fajokat is szerepeltetünk, amelyeknek sok az előfordulási adata, de azok közöletlenek, a faj pedig valamilyen szempontból fontos (pl. hazánkban törvényi oltalom alatt áll). Utóbbira példa a Peucedanum officinale, vagy az Aster sedifolius. 
Kistájak neveinek rövidítése:

$\begin{array}{lll}\text { BKk - Berettyó-Kálló köze } & \text { Élh - Érmelléki löszös hát } & \text { Ks - Körösmenti-sík } \\ \text { Bs - Bihari-sík } & \text { Ha - Hajdúhát } & \text { NS - Nagy-Sárrét } \\ \text { Bá - Borsodi-ártér } & \text { Há - Hevesi-ártér } & \text { SzTs - Szolnok-Túri-sík } \\ \text { DH - Dél-Hajdúhátság } & \text { Ho - Hortobágy } & \text { TKs - Tiszafüred-Kunhegyesi-sík } \\ & \text { KS - Kis-Sárrét } & \end{array}$

Adatközlők, gyűjtők neveinek rövidítése:

$\begin{array}{lll}\text { BA - Boruzs András } & \text { KÁ - Kiss Ádám } & \text { SI - Sándor István } \\ \text { BL - Bessenyei László } & \text { LBA - Lukács Balázs András } & \text { SZE - Szalma Elemér } \\ \text { DB - Deák Balázs } & \text { MA - Molnár Attila } & \text { TA - Takács Attila } \\ \text { EM - Endes Mihály } & \text { ME - Mizsei Edvárd } & \text { TG - Tihanyi Gábor } \\ \text { GG - Gulyás Gergely } & \text { MeA - Mesterházy Attila } & \text { TJ - Tar János } \\ \text { GL - Gebei Lóránt } & \text { MVA - Molnár V. Attila } & \text { TP - Török Péter } \\ \text { HI - Hődör István } & \text { NT - Nagy Tímea } & \text { VA - Vojtkó András } \\ \text { HJ - Hamar József } & \text { SA - Schmotzer András } & \text { VO - Valkó Orsolya } \\ \text { HD - Horváth Dénes } & \text { SG - Sramkó Gábor } & \text { VR - Ványi Róbert }\end{array}$

\section{Enumeráció}

Charophyta

---- Chara braunii C.C. Gmelin. - Gyakran jelenik meg időszakos vízállásokban gyepeken, szántóföldeken. Ined.: Ho: Hortobágy: Nagy-vókonya, a „Vókonya LIFE” területén [LBAMeA, 8393.3]. SzTs: Karcag: Magyarka, rizsföldeken [TA, det. MeA, 8791.3].

--- Chara vulgaris L. - Tapasztalataink szerint szikes tavaktól a szántóföldi belvizekig mindenhol megjelenhet. Lit.: SzUjKó-LACZA et al. (1982): Újszentmargita (8292). Ined.: BKk: Konyár: Kerek-szik-tó [LBA, 8695.4]; Csökmő: Borsodgyarmati-oldal [LBA, 8993.2]. Ho: Hortobágy: Nagy-vókonya, a „Vókonya LIFE” területén [LBA, 8393.3]; Balmazújváros: Nagyszik, A 2010-es nagy víz idején ecsetpázsitos sziki réten [LBA, 8394.3]. NS: Nagyrábé: Halomszer-dűlő, belvizes szántón [LBA, 8893.2]. Ks: Szeghalom: Kernye-dúlő [LBA, 8992.4].

---- Nitella obtusa T.F. Allen - Élőhelyi igényeit tekintve igénytelenebb, ezért előfordulása sokfelé várható. Ined.: DH: Derecske: Mérges, 47. sz. fóút 23,8 km-nél belvízfoltban [LBA, 8695.3]. Ha: Hajdúdorog: a belterület keleti szélén levő szikes laposon, sajnos, védelme késett, és anyaggödröt nyitottak benne [MA-LBA, 8195.3]. Ho: Hortobágy: Nagy-vókonya, a „Vókonya LIFE” területén [LBA, 8393.3].

\section{Bryophyta}

---- Ricciocarpus natans L. - A vizsgált térségben ritka, kevés a számára megfelelő élőhely. Tapasztalataink szerint a tiszta, áttetsző és hidegebb vizeket kedveli. Ined.: Ho: Hortobágy: Juhos-hát, a Pap-ere és a Hortobágy-f. közötti gyepen [LBA, 8392.4]. TKs: Kunmadaras: Kunmadarasi-puszta, a C-3 csatornában [MA, 8591.3]; Kunkápolnási-mocsár, a NagyDarvas-fenékben [MA-LBA, 8591.4]. 
Pteridophyta

29. Thelypteris palustris Schott - A vizsgált térségben ritka, kevés a számára megfelelő élőhely. Lit.: MolNÁr (2005): Balmazújváros: Nagyszik keleti oldala; Hajdúszoboszló: Kösely-meder. Ined.: Ho: Hortobágy: Hármas, a puszta déli részén, lápon [BL, 8492.1].

37. Asplenium trichomanes L. - A vizsgált területről alig van adata. A kutak, zsilipek jelenthetnek a faj számára megfelelő élőhelyet, de azokban is nagyon ritka. Lit.: MoLNÁR et al. (2017) Püspökladány és Nádudvar területéről jelzi. Herb.: Soó \& Máthé (1938): Kisújszállás: „Öregerdő". Ined.: Ho: Nádudvar: Nagy-lóré, a Holt-Kösely keresztgátján, a zsilip falán [LBA-MA, 8692.1].

42. Athyrium filix-femina (L.) Roth - A vizsgált területről szórvány adatai ismertek. Lit.: MolnÁR (2005): Tiszaderzs, Bartus morotva, néhány egyed. Ined.: Ho: Újszentmargita: Tilos-erdő [MA, 8292.4].

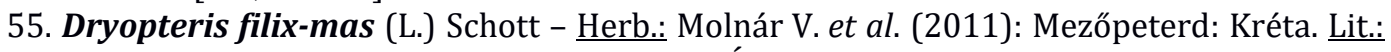
MolNÁR (2005): Tiszafüred, Kis-Jusztus és Újtikos, Nagy-erdő; TAKÁCS et al. (2016): Mezőpeterd: Kréta. Ined.: Ho: Egyek-Nagymajor: telepített tölgyesben [TA, 8391.2, 8391.4, 8392.3]. Nádudvar: Dusnak, a Holt-Kösely híd lábánál [LBA-MA, 8592.4].

60. Marsilea quadrifolia L. - Herb.: Siroki (1955, 1956): Hortobágy: Borsos; Siroki (1975): Hortobágy: Pentezug; Lukács et al. (2014): Kisújszállás: Kakat-ér. Lit.: SIMONKAI (1881): Kismarja: a Berettyó egykori holt ágainál. Soó (1948): Hortobágy: rizsültetvényeken. ZsÁK (1941): Nádudvar: a település nyugati határán, a Kis-Zádor vízereiben és vízállásos laposaiban. UBRIZSY (1949): Hortobágy, Tiszafüred. CSAPODY (1953): Hortobágy, Köröstarcsa. Boros (1960): Kisújszállás; Karcag. EndEs (1982): Karcag. SzABó L. in SzujKóLACZA et al. (1982): Kunmadaras. SEREgélyes (1999): Tiszafüred; Kunmadarasi-puszta. MolnÁr V. \& PFEIFFER (1999): Kunmadaras: C3-as csatorna (MolnÁr A. ex verb.); Tiszafüred (FARKAS S. ex verb.). MolnÁr (2005): Kunmadaras: C-3 csatorna. Szalma E. in MolnÁR (2005): Tisza-tó. VojtKó A. in MolnÁr (2005): Tisza-tó. LESKU \& Molnár (2007): Tisza-tó. MolnÁr (2013): Kunmadaras: C-3 csatorna; Hortobágy: Öreg-tó; Nádudvar; Folyás. Ined.: Há: Újlőrincfalva: Tisza-tó: Óhalászi-sziget (SEREgéLYES 1999 és MoLNÁr V. \& PFEIFFER 1999 tiszafüredi adatának eredetije) [EM, 8490.1]; Tisza-tó: Kozma-fok K-i oldala (SzALMA E. in Molnár 2005 adatának pontosítása) [HJ-SZE, 8489.2]; Poroszló: Tisza-tó: Kőhíd-lapos, horgászálláson (VoJTKó A. in MoLNÁr 2005 adatának pontosítása) [VA, 8390.3]; Tisza-tó, az V. sz. öblítőcsatornától D-re (a tározó elárasztása előtt Danyi puszta), gyalogakác miatt kiritkuló nádasban, nagy egyedszámban [MeA, 8489.2]. Ho: Hortobágy: Öreg tavak, a Kondás-tó leeresztett felszínén 3 nagyobb foltban (MoLnÁR 2013 adatának eredetije) [TJLBA, 8392.2]; Folyás: a Bivalyhalmi-halastó leeresztő csatornájában, kis egyedszámban (Molnár 2013 adatának eredetije) [TJ, 8292.2]; Nádudvar: Sós-kút-telek, kiszáradt sekély árokban, néhány tő (MolNÁR 2013 adatának eredetije, ZsÁk 1941 adatának megerősítése). Érdekes, hogy az EOTR 1:10 000 és a Gauss-Krüger 1:25 000 arányú térképlapokon egyaránt jelzett Sós-kút-telek pusztarész neve a korábbi térképeken - beleértve a kéziratos térképeket is - Kis-Zádor, utóbbi megnevezés azonban mára kiveszett) [HI, 8592.3]. SzTs: Kisújszállás: Varjas, rizsföldi árasztó csatorna medrében ezerszám (BoRos 1960 adatának megerősítése) [KÁ, 8790.4]; Karcag: Bócsa-legelő, a dűlő É-i szélén futó csatornában [ME, 8790.2] (Boros 1960 adatának megerősítése).

Megjegyzés a mételyfű Tisza-tavi előfordulásáról: Úgy tűnik, eredetileg Endes Mihály találta 1983-ban az Óhalászi-szigeten, 10-15 tőre emlékszik (Endes ex verb.). (Ez valójában Újlőrincfalva külterület). Később Szalma Elemér és Hamar József is megtalálta (Szalma ex litt.), a Kozma-fok mellett, 1990 körül, majd Vojtkó András (Vojtkó ex verb.) Vida Gábor és Pócs Tamás társaságában látta 1998-ban vagy 1999-ben Poroszló külterületén (ez az adat 
került be MoLNÁR 2005-be). Megjegyezzük, hogy Ubrizsy már 1949-ben közölte Tiszafüredről (lásd az irodalmi adatok közt), de vélhetően a domoszlói rizsföldeken látta.

63. Azolla filiculoides Lam. - Nem ismerünk más adatot a térségből. Ritkának gondoljuk. Ined.: Ho: Hortobágy (Malomháza): a bemutatóterület dísztavában, 2015 nyarán szaporodott el [MA, 8492.4].

\section{Angiospermae}

102. Salix caprea L. - Herb.: Soó \& MÁTHÉ (1938): Hortobágy: Taskony p. Lit.: MolnÁR (2005): Nagymacs. Ined.: Ho: Egyek-Tiszacsege: az Ohati-erdőben kevés, az erdő környékén itt-ott több is [MA, 8391.4].

151. Thesium ramosum Hayne - Herb.: Soó (1935): Hajdúnánás: Kajánszék; Felföldy (1942): Hajdúszoboszló; Siroki (1948): Egyek: Ohat-Pusztakócs; Siroki (1948): Egyek: Ohati-erdő. Lit.: RAPAICS (1916): Nagyhortobágy, mátai kaszáló; UJvárosı (1937): Hajdúnánás; Soó (1934c): Debrecen (Tocómente); TAMÁSSY (1927): Hortobágy; TAMÁsSY in Soó \& MÁTHÉ (1938): Szepes; Soó (1948): Ohat; MoLNÁr (2005): Újszentmargita: Tilos-erdő; Nagymacs, 3316. sz. út; Tiszafüred: Meggyes-lapos. Ined.: Ho: Nagyhegyes: az Alsó-KadarcsKösely főgyűjtő-csatorna löszös depóniáján, a Dóka-legelő közelében [GG, 8493.3]. NS: Püspökladány: Udvari-határ-dúlő, földút mezsgyéjében [SA, 8793.1]; Biharnagybajom: Malom-köz [SA, 8793.3].

152. Thesium dollineri Murb. - Herb.: SzUjKó-LACZA et al. (1982): Balmazújváros. Lit.: Soó (1934c): Balmazújváros; UJvárosi (1937) Hajdúnánás: Kajánszík. Ined.: NS: Püspökladány: Mérgesér-hát [MA, 8792.1].

191. Rumex pseudonatronatus Borbás - Herb.: SZUjKó-LACZA et al. (1982): Újszentmargita. Lit.: BOROS in SZABó et al. (1973): Újszentmargita; MoLNÁR (2005): Az Ohati-erdő vasúttól Kre eső idős tölgyesének tisztásán; DEÁK et al. (2008): a 33. sz. út mentén Hortobágytól Tiszafüredig többfelé. Ined.: Ho: Kunmadaras: volt orosz katonai reptér, a hátsó hangároknál, sziki kocsorddal [MA, 8690.1]; Tiszafüred: Vígh-tanya: a tanyától Ny-ra eső sásos mederben [GG, 8491.2]; Egyek: Nagy-Meggyes: a Fekete-rét táplálócsatorna mellett a szántó szegélyében [GG, 8491.2]. TKs: Tiszafüred: Nagy-állás, földút mentén több kisebb állománya [LBA, 8491.4].

199. Rumex sanguineus L. - Ined.: Ho: Egyek: Ohati-erdő [MA, 8391.4].

218. Chenopodium rubrum L. - A Crisicum déli részein gyakori faj itt kimondottan ritka. Herb.: Polgár (1915): Hajdúszoboszló; Simon (1947): Tiszacsege. Lit.: TAMÁssy (1927): Hortobágy; SimONKAI (1881): Nagyrábé és Biharnagybajom közt: Nagyréti puszta; MolNÁr (2005): Balmazújváros: Nagyszik; Angyalháza: a Tárkány-fok fölött. Ined.: DH: Derecske: Morgó [LBA, 8695.3]; Nádas-szik-tó [LBA, 8695.1].

243. Kochia prostrata (L.) Schrad. - Herb.: Magyar (1922): Egyek; Soó (1947): Egyek; Siroki (1947): Egyek; Siroki $(1958,1962):$ Hortobágy; Sramkó \& Takács (2014): Hortobágy. Továbbá SzujKó-LACZA et al. (1982): Halastó; Kungyörgy; Nagyiván-Kunmadaras; Ohat. Lit.: Kitaibel in KanitZ (1863): Egyek; Kerner (1875): Kisújszállás, Egyek; Magyar (1928): Hortobágy, Tiszacsege, Egyek, Püspökladány; Soó (1948): Ohat; BoDrogKözy (1965): Árkuspuszta, Mátapuszta; SzujKó-LACZA et al. (1982): Zám-puszta; Nagyiváni-puszta. Ined.: Ho: Tiszafüred: a Kondás-halom és a Csepregi-lapos között [GG, 8491.2]; a 33 sz. fóút Ny-i oldalán, az 57. és az 58. km között [GG, 8491.2]. NS: Nagyrábé: Csata-lapos [SG, 8793.4].

245. Bassia sedoides (Pall.) Asch. - A Hortobágy déli felének jellegzetes libatopféléje. Herb.: Soó (1934): Hortobágy-Halastó; Siroki (1947): Hortobágyi halastó; Igmándy \& Igmándy (1948): Püspökladány, Farkasérhát; Károlyi (1949): Biharnagybajom; Siroki (1969): Püspökladány, útszélen; Lukács et al. (2012): Karcag, Kecskeri-puszta; Sramkó \& Takács 
(2014): Hortobágy-Szásztelek. Továbbá Soó \& MÁTHÉ (1938): Karcag. SzujKó-LACZA et al. (1982): Nagyiván; Ohat. Lit.: TuzSon (1920): Püspökladány; MAGYAR (1928): Hortobágy; Zsák in Soó \& MÁthé (1938): Kunmadaras „Kunkápolnás”; Karcag; Soó \& MÁtHÉ (1938): Kisújszállás; Boros in Soó \& MÁTHÉ (1938): Karcag; MolnáR (2005): Karcag; Nagyiván; Ágotapuszta; Pentezug-Malomháza; Angyalháza. Ined.: Ho: Kunmadaras: volt orosz katonai reptér [MA, 8690.1]; Nagyiván: padkás vaksziken, a falutól délkeletre [MA, 8591.2]; Nádudvar: az egykori bombázó lőtéren (Borzas) szórványos [MA, 8592.3]; Sós-kút-telek [HI, 8592.3]. NS: Püspökladány: Mérgesér-hát mezsgyéiben [MA, 8792.1]; Közép-hát, az ÚjKővágói-csatorna partján [SA, 8792.1]. TKs: Karcag-Kunmadaras: Ecse-halom és környéke [MA, 8591.4]; Karcag: Disznó-rét [MA, 8691.2].

250. Salicornia prostrata Pall. - Herb.: Takács (2014): Hortobágy. Lit.: SzABÓ in SzujKó-LACZA et al. (1982): Hortobágy; KovÁCS in SZUjKó-LACZA et al. (1982): Nagyiván; MoLnÁR (2005): Hortobágy, Nagyiván többfelé. Ined.: Ho: Hortobágy: az akadémiai szikeseken [MA, 8492.1]; a Pentezug és a Zámi-fok kopárosain [MA, 8492.3]; Tiszafüred: Nagyiváni-puszta, a Lyukashalomnál [MA, 8491.4]. TKs: Karcag: Ecsezug, Digógödör-fertő [MA, 8691.2].

253. Suaeda salinaria (Schur) Simonk. - MILE \& WALTER (2003) illetve BARTHA et al. (2015) alapján tiszántúli és erdélyi elterjedést mutat. A Magyarországon honos három sóballa faj taxonómiai revízióját MILE \& WALTER (2003) végezte el. A korábbi taxonómiai bizonytalanságok miatt a nemzetség összes fajának a területre vonatkozó nem recens irodalmi adatait feltételesen kell kezelni. Herb.: Siroki (1955): Hortobágy (S. maritima agg, nem revideált lapok); Takács (2012): Hajdúnánás, (2014): Hortobágy-Szásztelek. Lit.: JANKA (1866): Konyári Sóstófürdő; Rapaics (1916): Hortobágy; MAGYAR (1928): Balmazújváros; SZUJKó-LACZA et al. (1982): Zám-puszta; MolNÁr (2005): Hortobágy, Zám, Kékes, Hármas; Balmazújváros, Virágoskút, Nagyszik; Nagyiván. Ined.: DH: Hajdúszoboszló: Angyalháza [MA, 8492.4]; Berettyóúffalu: Nagy-Andaháza, Sárréti-fcst. és a Keleti-fcst. által határolt része [LBA, 8794.2]. Ho: Hortobágy: az akadémiai szikeseken [MA, 8492.1]; Pentezug, a Tornyi-domb körül [MA, 8492.4]; Pentezug, a Zámi-fok kopárosain [MA, 8492.3]; Nádudvar: Bombatéren többfelé, de különösen sok a Zádor-lapos északkeleti partján, és a Borzasi-erdő alatt [MA, 8591.2, 8592.1]; Sóskút-telek, az egykori bombázó lőtér déli területrészén [LBA, 8592.3]. TKs: Karcag: Ecsezug, Digógödör-fertő [MA, 8691.2].

254. Salsola soda L. - Nem gyakori. Herb.: Soó (1932): Balmazújváros; Soó (1934): Hortobágy-Halastó; Újvárosi (1935): Hajdúnánás; Siroki (1972): Mikepércs; Siroki (1975): Konyári Sóstó. Lit.: TAMÁsSY (1927): Hortobágy; MAGYAR (1928): Hortobágy (Csécsi tavak); IGMÁNDY (1933): Hajdúnánás; Soó \& MÁTHÉ (1938): Balmazújváros; MolNÁr (2005): Nagyiván; Karcag, Kecskeri-Magyarka. Ined.: DH: Mikepércs: Kornyó-lapos, a mocsár K-i szegélyén [GG, 8595.3]. Ho: Kunmadaras-Nádudvar: a közigazgatási határt jelölő Köles-érigát mentén [LBA, 8592.3]; Nádudvar: Daru-erdő Ny-i szélén, keréknyomban [LBA, 8591.2]; a Bombatéren (Borzas) szórványos sokfelé megtalálható [MA-LBA, 8592.3]; Kis-tejfeles [HI, 8592.3]; Sós-kút-telek [HI, 8592.3]; Hortobágy: Zám-Kenderátó körül [MA, 8491.4].

278. Montia fontana L. subsp. chondrosperma (Fenzl) Walters - Lit.: JAKAB \& MOLNÁR V. (2005): Hencida: Csere-erdő. Ined.: BKk: Kismarja: Bor-sziget, a dülő DK-i részén [GG, 8797.1]; Pocsaj: Dobogó [GG, 8797.1]; Három-ágú, mocsár szélén és szikes gyepen, valamint a Kasza-parttól D-re, nagy kiterjedésű legelőn-kaszálón [GG, 8797.1]. Bs: Kismarja: Vakaró-dűlő, mocsárfolt szegélyében [GG, 8796.4].

298. Stellaria palustris Retz. - Herb.: Ujvárosi (1937): Hajdúnánás: Mélyér; Molnár V. et al. (2011): Berettyóújfalu: Tardi-szik melletti erdőben. Lit.: UJvÁrossy (1936): Hajdúnánás; SimonKAI (1881): Kismarja és Pocsaj között (Stellaria Laxmanni Fisch. az eredeti közlésben!); MoLnár (2005): Polgár, Vargahalmi-dűlő. Ined.: Ho: Görbeháza: Malomzugilegelő [MA, 8193.1]; Nagyhegyes: a Nyírő-rétjén [MA, 8493.1].

348. Silene bupleuroides L. - Lit.: MÁTHÉ (1932): Kishegyesi-út m. (Debrecen); MolNÁR 
(2005): Hajdúszoboszló, 4. sz. főút. Ined.: NS: Sárrétudvari: Földes-Hangás, a Hamvascsatorna partján [SA, 8793.1]; Püspökladány: Udvari-határ-dűló, a Hamvas-csatorna partján [SA, 8793.1].

349. Silene multiflora (Waldst. et Kit.) Pers. - Herb.: Juhász (1933): Sáránd-Hajdúbagos; Ujvárosi (1935): Hajdúnánás-Tedej; Kovács (1936): Hencida: Cserjekaszáló; Soó (1937): Hajdúbagos; Kállay (1943): Hajdúnánás: Nagylegelő. Továbbá SzujKó-LACZA et al. (1982) szerint Gombocz: Hortobágy (BP) valamint Soó \& MÁTHÉ (1938) szerint Kovács: Gáborján. Lit.: UJvÁRossY (1936): Hajdúnánás; MolNÁR (2005): Polgár, Vargahalmi-dűlő (helytelenül állapítja meg, hogy korábban nem jelezték a Tiszántúlról). Ined.: Bá: Újszentmargita: a Tilos-erdő alatt a majornál, kevés [MA, 8292.3]. Ho: Hortobágy (Borsós): a Borsósitározótól északra eső réteken [MA, 8492.2]; Gombocz adatának aktuális megerősítése.

375. Dianthus armeria L. - Herb.: Soó (1932): Ohat; Kovács (1936): Hencida: Cserjekaszáló; Igmándy (1937): Hajdúnánás: Előhát. Lit.: MÁTHé (1933): Ohat-erdő; UjvárossY (1936): Hajdúnánás; Soó \& MátHÉ (1938): Hencida-Gáborján; MÁTHÉ (1939): Hencida: Cserje-erdő; TAllós \& TóTH (1968): Újszentmargita; MolNÁr (2005): Újtikos, Köröstói-erdő; Hajdúnánás-Tedej. Ined.: TKs: Kunmadaras: a volt szovjet reptéren [MA, 8690.2].

384. Ceratophyllum submersum L. - Herb.: Ujvárosi (1935): Hajdúnánás: Kajánszik; Siroki (1947): Hortobágy: halastó. Lit.: UjvárossY (1936): Hajdúnánás; Soó \& MátHÉ (1938): Konyár; ZsÁK (1941): Püspökladány; MoLNÁr (2005): Nádudvar: Kösely. Ined.: Ho: Tiszacsege (Cserepes): Rókás [MA, 8392.2].

391. Nigella arvensis L. - Herb.: Kovács (1928): Hencida; Felföldy (1934): Hortobágy: vasút mentén; Soó (1937): Hajdúszoboszló; Igmándy (1947): Hajdúnánás: út mentén Hajdúdorog felé. Továbbá SzuJKó-LACZA et al. (1982) szerint Siroki (1960): „Hármas” valamint Tóth (1979): Nagyiván (HK). Lit.: Soó \& MÁTHÉ (1938) szerint közönséges. Ined.: NS: Püspökladány: Hamvas csatorna, a 42-es út mellett [GG, 8793.1]; Udvari-határ-dűlő, a Hamvas-csatorna partján [SA, 8793.1]. Sárrétudvari: Malom-köz, földút mezsgyéjében [SA, 8793.3].

397. Caltha palustris L. - Lit.: Soó \& Máthé (1938) és SzUJKó-LACZA et al. (1982) szerint közönséges, MoLNÁr (2005) sem közöl róla előfordulási adatot, ugyanakkor a vizsgált területről származó herbáriumi példányát nem találtuk, és BARTHA et al. (2015) térképe is azt sugallja, hogy elsősorban a Tiszántúl peremein elterjedt, míg belsőbb területeiről jóformán hiányzik. Ined.: Bs: Mezőpeterd: Ölyvös-csatorna, a 42-es főút közelében [GG, 8895.2].

418. Clematis integrifolia L. - Míg a Körös-vidéken és a Jászságban löszgyepeken is megtalálható, addig a Crisicum ezen a részén csak folyóparti gyepeken vagy töltésen él. Herb.: Siroki (1947): Egyek, Tisza-part; Simon (1947): Geszt; Simon (1950): Egyek, a Tisza és az Ohati-erdő között. Lit.: SIMONKAI (1890): Bors, Kőröstarján; MoLNÁR (2005): Tiszacsege: Tisza töltés. Ined.: Bs: Ártánd: Drága-oldal [SG, 8896.2]; Proletár-dűlő, a Zomlini-csatorna partján [SG, 8896.2]. Bedô: Proletár-dúlő, a Zomlini-csatorna partján [SG, 8896.2]; Zomlini-csatorna közelében, földút mezsgyéjében [SG, 8896.2]. Biharkeresztes: 42es fóút mezsgyéje [GG, 8896.3]. Kismarja: Berettyó jobbparti gyepen, a Fekete-tanya és az országhatár között [GG, 8797.1]; Berettyó jobbparti gyepen, az országhatár közelében [GG, 8797.1]; a Berettyó hullámterében, az országhatáron [GG, 8797.3]; a pocsaji Csonta és a Fekete-tanya között, a Berettyó mentén húzódó fajgazdag sztyepréteken [GG, 8797.1]; az országhatáron, a G59-G60 határköveknél [GG, 8797.1].

427. Adonis aestivalis L. - A '90-es években egy ideig viszonylag elterjedt volt, újabban megint visszaszorulóban. Lit.: TAKÁcs et al. (2014b): Hajdúböszzörmény-Pród. Herb.: Máthé (1932): Egyek; Soó (1934): Sáránd; Soó (1935): Püspökladány; Kovács (1936): Gáborján; Molnár V. \& Takács (2014): Hajdúböszörmény-Pród. Ined.: DH: Hajdúszoboszló: Kéthalom [MA, 8593.3]. NS: Bihardancsháza: Tupor-dúlő, a Halom-szer D-i lábánál [LBA, 8793.4]. TKs: Kunmadaras: Oktalan-lapos [MA, 8590.4]. 
430. Ranunculus aquatilis L. - Taxonómiai bélyegeikben átmeneti formát mutató példányok sora került elő a Hortobágyról, amelyek a $R$. aquatilis, $R$. peltatus, $R$. petiverii és $R$. baudotii alakok közötti átmeneteket mutatták. Feltehetően a $R$. aquatilis különböző ökotípusairól lehet szó. Herb.: Soó (1930): Püspökladány; Máthé (1932): Egyek; Siroki (1947): Hortobágy, (1961): Biharugra, (1959): Mezőpeterd; Simon et al. (1950): Egyek; Babai (1961): Tiszafüred. Lit.: Soó \& Máthé (1938): Ohat, Hortobágy, Püspökladány, HencidaGáborján, Biharugra, Nagyvárad, Kőröstarján; BoDRoGKÖZY (1965): Máta; SzUjKó-LACZA et al. (1982): Nagyiván. Ined.: BKk: Konyár: a Derecskei műút 6,5 km-énél [LBA, 8695.4]. Bs: Berettyóújfalu: Peresi-legelő [LBA, 8895.2]. DH: Derecske: Mérges, 47. sz. foút 23,8 km-nél [LBA, 8695.3]. Ho: Hortobágy: Szásztelek felé vezető műút menti árokban [LBA-MeA, 8492.1]; Nagy-vókonya, a „Vókonya LIFE” területén [LBA-MeA, 8393.3, 8393.1]; Juhos-hát, a Pap-ere és a Hortobágy-f. közötti gyepen [LBA, 8392.4]. Tiszacsege: Kis-Kecskés Ny-i része, műút melletti laposban [LBA, 8392.1]. Újszentmargita: Dinnyés-lapos [LBA, 8392.2]. Balmazújváros: Kis-Cserepes, múút melletti árokban [LBA, 8392.2]; Nagy-szik [LBA, 8394.3]; Darassa, műút melletti árokban [LBA, 8392.2]. TKs: Tiszafüred: Fekete-rét [LBAMeA, 8491.2].

433. Ranunculus rionii Lagger - A magok mérete és száma alapján a könnyebben határozható víziboglárkák közé tartozik, ennek ellenére csak szórvány adatai vannak, valószínűleg gyakoribb, mint az adatai mutatják. Herb.: Soó (1949): Konyár. Ined.: Ho: Hortobágy: Nagy-vókonya [LBA-MeA, 8393.3, 8393.1]. TKs: Karcag: Ecsezug, Digógödörfertő [MA, 8691.2].

437. Ranunculus illyricus L. - Lit.: Soó \& MÁTHÉ (1938): Kisújszállás; SzUJKó-LACZA et al. (1982): Nagyiván; Molnár (2005): Hortobágy, Máta-Darassa, Hajdúszoboszló, belterület. Ined.: BKk: Pocsaj: Háromágú, cserjésedő magaslaton [GG, 8797.1].

439. Ranunculus lateriflorus DC. - Zsombékosodó szikes réteken, a Hortobágyon általánosan elterjedt, másutt szórványos. Herb.: Magyar (1923): Püspökladány; Soó (1932): Balmazújváros; Soó (1935): Hajdúnánás; Felföldy (1936): Hortobágy; Máthé (1936): Sáránd; Kovács (1937): Hencida: Cserjeerdő; Siroki (1947, 1959, 1961, 1986): Hortobágy; Siroki (1947): Egyek: Ohat; Molnár (2003): Püspökladány: Dögös-lapos. Továbbá SzujkóLacza et al. (1982): Darassa; Hortobágy; Ohat. Lit.: Soó \& MÁthé (1938): Szikes mocsarakban közönséges; BoDRoGKözY (1965): Árkuspuszta, Mátapuszta; SzABó in SzUjKóLACZA et al. (1982): Nagyiván-Kunmadaras; MoLNÁr (2005): Zsombékosodó szikes rétek semlyékeiben elég általánosnak mondható, különösen a déli pusztákon. Ined.: BKk: Pocsaj: a Kasza-parttól D-re, nagy kiterjedésű legelőn-kaszálón [GG, 8797.1]. Bs: Darvas: Nagykaszáló [SG, 8894.3]; mentett oldali tölgyes, a Berettyó töltés mellett [GG, 8993.2]; Esztár: Nyomás-csere, mocsárfoltban [GG, 8796.2]; Kismarja: Fóka-part [GG, 8797.3]; Középső-szik [GG, 8796.2]; Zsáka: Nagy-kaszáló [SG, 8894.3]. Ho: Hortobágy: Juhos-hát, a Pap-ere és a Hortobágy-f. közötti gyepen [LBA, 8392.4]; Juhos-háti erdő szélén [LBA, 8393.3]; Zám (Halas) [MA, 8592.1]; Balmazújváros: Nagy-szik [LBA, 8494.1]. TKs: Kunmadaras: Kunmadarasi-puszta, a Kondás-fertő környéki zsombékosokban [MA, 8591.3].

440. Ranunculus polyphyllus Waldst. et Kit. - Herb.: Molnár (2003): Püspökladány: Dögöslapos; Sramkó \& Gulyás (2007): Egyek-Telekháza; Gulyás (2010): Darvas. Továbbá Soó \& MÁTHÉ (1938): Kisújszállás; SzUJKó-LACZA et al. (1982): Püspökladány. Lit.: KITAIBEL \& WALDSTEIN (1802): Bihar megyében; a Hortobágy (Hartobágy) csatornában; Karcag és Püspökladány között; KERnER (1867): Hortobágy; Berettyóújfalu; Püspökladány; JANKA in STEFFEK (1864): Püspökladány; JANKA (1865): Földes; HAZSLINSZKY (1872): Tiszántúli mocsarakban szórványosan, különösen a Hortobágyban; Soó (1932): Ohat; Soó (1932): Ohati-erdő mocsarai; MÁTHÉ (1933): Ohati-erdő; JávorKa (1935): Karcag; SzABó in SzujKóLACZA et al. (1982): Nagyiván; GőRI in MolnÁR V. et al. (2000): Tiszafüred: Hagymás-lapos; MolnÁR V. et al. (2000): Tiszacsege és Egyek-Telekháza között; Egyek: a 33-as főút mellett a 
Meggyes-csárdai leágazónál; Polgár: Varga-halmi-dúlő; Hencida: Csere-erdő; MoLNÁR (2005): Hajdúszoboszló, Kösely part, Gátoldali legelő; Tiszacsege-Egyek, műút menti laposokban; a halastavi bekötőút két oldalán, a kékesi zsombékosokban, Egyek, Csattaglapos; Tiszafüred: Hagymás-lapos, Hortobágy, Pentezug, Kincses-lapos, Zám, Nagyiván, Kunkápolnás; Ágotapuszta: Dögös; Polgár körüli legelők. A közölt adatokhoz képest jóval elterjedtebbnek tartja; MoLNÁR V. in MoLNÁR (2005): a 33. sz. főút mellett a Meggyes-csárdai leágazónál. Ined.: BKk: Berettyóújfalu: Nagy-hídköz, a Berettyó mentett oldali árterén [LBA, 8795.3]; Kismarja: A Fekete-tanya K-i szegélyén, ültetett tölgyesben húzódó mederben [GG, 8797.1]; Bor-sziget, a dűlő DK-i részén, mederben [GG, 8797.1]; Dobogó, lápos mederben [GG, 8797.1]; Palló-erdő, mederben [GG, 8797.1]; a pocsaji Csonta és a Fekete-tanya között, mocsárban [GG, 8796.2, 8797.1]; Pocsaj: Dobogó, mocsárban [GG, 8797.1]; Háromágú, mocsárfoltokban mindenütt [GG, 8797.1]; Kasza-puszta, a Repcés-tóban [GG, 8797.1]; Kaszapuszta, mocsárban [GG, 8797.1]. Bs: Darvas: mentett oldali tölgyes, a Berettyó töltés mellett [GG, 8993.2]; Esztár: Törzsökös, mederben [GG, 8796.2]; Hencida: Miklósi-erdő, holtmederben [GG, 8796.3]; Miklósi-erdő, mély mocsárban az erdő ÉNy-i részén [GG, 8796.1, 8796.3]; Nagy-terebed, mocsárfoltban [GG, 8796.3]; Kismarja: Füzes-gát [GG, 8796.1]; Nagymarjai-dűlő, mederben [GG, 8796.2]; az Esztár-Nagymarjai-mellékcsatorna D-i oldalán, mocsárfoltban [GG, 8796.2]; mederben, a lokalizációs töltés D-i végénél [GG, 8797.3]; Óriáspart [GG, 8796.2]. Ho: Hortobágy: Nagy-vókonya [LBA, 8393.3, 8393.1]; Juhos-hát, a Pap-ere és a Hortobágy-f. közötti gyepen [LBA, 8392.4]; Nádudvar: Bombatér, bombatölcsérekben a Kölesgát mellett [MA, 8591.4]; Tiszafüred: a Tarhos-laposnál a meggyescsárdai lejáró közelében [MA, 8491.2]. KS: Csökmő: Őzpár [LBA-MVA, 8993.3]. NS: Püspökladány: Kis-Kunlapos, 4. sz. fő́t déli oldala melletti árokban, nagy számban [LBA, 8692.3]. TKs: Kunmadaras: Nagy-legelő, Nagy-Füves-halomtól Ny-ra [LBA, 8591.3].

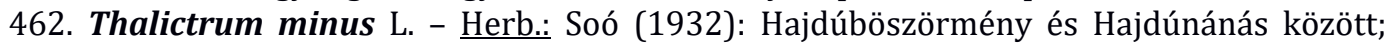
Ujvárosi (1935): Hajdúnánás; Siroki (1949): Debrecen-Ondód; Takács (2013): Hosszúpályi-Pocsaj. Továbbá Soó \& MátHÉ (1938): Tiszafüred; SzujKó-LACZA et al. (1982): Balmazújváros: Papházi-erdő; Ohat: Halastavak. Lit.: UJvÁrosı (1937): Hajdúnánás: Puszta; SzujKó-LACZA et al. (1982): Hortobágy: Zámpuszta; Tóth in SzujKó-LACZA et al. (1982): Juhoshát, Darassa, Nagyiván; Egyek (Ohat); TAKÁcs et al. (2016): Sárrétudvari, temető. Ined.: Bs: Nagykereki: Országhatár, a G34/2 határkő közelében [SG, 8897.1]. Ho: Tiszafüred: a Nyugati-fő́csatorna és a Meggyes-erdő között, földút melletti háton [GG, 8491.2]; Nagyhegyes: Kis-Álomzug, az Alsó-Kadarcs-Kösely főgyűjtô-csatorna Ny-i oldalán, földút menti mezsgyén [GG, 8493.3].

466. Thalictrum lucidum L. - Herb.: Ujvárossy (1936): Hajdúnánás: Mélyér; Igmándy (1937): Hajdúnánás: Előhát; Kovács (1938): Hencida: Cserjekaszáló; Siroki (1947, 1949): Egyek. Továbbá Soó \& MátHÉ (1938): Hencida-Gáborján; Hortobágy: Kecskés p.; Kisújszállás. Lit.: RAPAICS (1916): Nagyhortobágy, Mátai kaszáló; TAMÁssY (1927): Hortobágy; Soó (1934c): Tiszafüred-Poroszló, Heves m.-ben; SzujKó-LACZA et al. (1982): Nádudvar. Ined.: Ho: Hortobágy: a Kadarcs-Karácsonyfok-csatorna torkolatához közeli réteken [MA, 8393.3]; Máta, a Sárkány-kunyhótól északra [MA, 8392.4] (RAPAICS 1916 adatának megerősítése).

499. Sisymbrium polymorphum (Murray) Roth. - Országosan igen ritka faj. Lit.: MoLNÁR (2005): Hajdúszoboszló: Két-halom. Ined.: Élh: Létavértes: az Ér-fcst. északi oldalában, az országhatár közelében a löszletörésen, 1-2 ezer példány [GL, 8697.3].

504. Myagrum perfoliatum L. - A Tiszántúl É-K-i részén ritka. Herb.: Soó \& MáTHé (1938): Karcag. Lit.: KERNER (1867): Kisújszállás. Ined.: TKs: Tiszafüred: Kosárhát [MA, 8591.3].

506. Bunias orientalis L. - A Tiszántúlon már ritka faj elterjedésének súlypontja keletre esik, a Partiumban és Erdélyben gyakori. Lit.: MolNÁR (2005): Karcag: Apavári-híd körüli vasúti mezsgyékben; TAKÁCS et al. (2016) ugyaninnen közlik. Ined.: Bs: Nagykereki: Csárda-domb 
[SG, 8896.2]; Ártánd: Zavart faluszéli gyepekben, a település K-i szélén [SG, 8896.4].

527. Rapistrum perenne (L.) All. - A Crisicum-ban ritka faj. Herb.: Siroki (1947): Debrecen, vasút mentén. Továbbá SzUJKó-LACZA et al. (1982): Hortobágy: Látókép. Lit.: UJVÁRoSI (1937): Hajdúnánás: Puszta; TAMÁssy (1927): Debrecen; Soó \& MÁtHÉ (1938): Hajdúszoboszló; MoLNÁR (2005): Hajdúszoboszló: Cifra-halom; (Debrecen-)Nagymacs és (Balmazújváros-)Nagyhát között eltúnt. Ined.: Ho: Hortobágy: Máta: Papegyházán szórványos [MA, 8392.4].

569. Draba nemorosa L. - Herb.: Siroki (1947): Debrecen, vasúti töltésen. Lit.: TAMÁssY (1927): Debrecen. Ined.: Ho: Hortobágy: Juhos-hát [MA, 8392.4].

637. Sedum caespitosum (Cav.) DC. - Az országosan ritka faj főképp a Crisicum déli területeiről ismert. - Ined.: BKk: Pocsaj: Kasza-puszta, a MOL-út szegélyében [MA, 8797.1]; Dobogó, ürmös szikesben [GG, 8797.1]. Bs: Kismarja: Fóka-part, ürmös szikesben [GG, 8797.3]; Lápis-tó [GG, 8796.4]; az Esztár-Nagymarjai mellékcsatorna D-i oldalán, ürmös szikes foltban [GG, 8796.2].

685. Rosa gallica L. - Herb.: Máthé (1932): Egyek: Ohat; Ujvárosi (1935): Hajdúnánás: Puszta; Siroki (1948): Hortobágy: Ohati-erdő; Molnár V. et al. (2011): Berettyóújfalu: Tardiszik. Lit.: Kitaibel in Kanitz (1863): Debrecen; HazslinszKY (1872): Debrecen mellett; RAPAICS (1916): Nagyhortobágy; TAMÁssy (1927): Kösélyszeg; MÁTHÉ (1933): Ohati-erdő; Soó (1937): Hajdúnánás, Hajdúdorog; Ujvárosi (1937): Hajdúnánás: Puszta; TALLós \& TóTH (1968): Újszentmargita; MoLNÁR (2005): Hajdúszoboszló: Dóka-dűlő; Hajdúszoboszlótól Kre a régi 4. sz. főút mezsgyéjében; DEÁK et al. (2015): Hencida, Mondró-halom. Ined.: BKk: Berettyóúffalu: Tardi-szik [SG-TA, 8795.3]. NS: Püspökladány: Udvari-határ-dűlő, a Hamvascsatorna partján [SA, 8793.1]; Sárrétudvari: Malom-köz, földút mezsgyéjében [SA, 8793.3].

687. Rosa agrestis Savi - Elterjedése hiányosan ismert, adatait a térségben nem gyüjtik. Lit.: Ujvárosi (1937): Hajdúnánás: Kajánszik. Ined.: Ho: Ujjszentmargita: Kos-Hodály, a Dinnyéslapostól É-ra, a 7-es öntözőcsatorna depóniáján [GG, 8292.4]; Tiszacsege: Kis-Kecskés, az Öreg-tavakat É-ről határoló depónián [GG, 8392.2]. BKk: Berettyóújfalu: Korhány-dúlő (Bántó-tanya): felhagyott homokbányában, százas nagyságrendben. Ennek közelében a 47es számú út mentén is [GG, 8795.1].

690. Rosa rubiginosa agg. - A vizsgált térségben egyáltalán nem ritka. Az utóbbi 15 év kutatásai alapján kijelenthető, hogy a Hortobágyon szinte mindenütt előfordul. Néhol, pl. Balmazújváros: Nagy-Vókonyán az egyedszáma eléri vagy meg is haladja a Rosa canina agg. alakokét. Lit.: UJVÁROSI M. (1937): Hajdúnánás, Kajánszik (R. agrestis b. inodora néven); TAKÁcs et al. (2014b): Folyás, Hajdúnánás, Újtikos. Ined.: Bs: Berettyóúffalu: Nagy-Revickilegelő, a 42-es fóút közelében [GG, 8895.1]. DH: Hajdúszoboszló: régi 4. sz. út mente [MA, 8594.3]. Ho: Balmazújváros: a Magdolna nevü határrész legelőjének északkeleti sarkában lévő vályogvető gödreiben sok. Ennek közelében máshol is a legelőn elszórva [HD, 8493.2]; Darassa [MA, 8393.1, 8393.2, 8393.3]; Nagyhegyes: Nyírőlapos határrészen löszgyepfoltokban és a 33-as úttól délre eső Alföldi-erdővel érintkező gyepeken is előfordul. Az erdőtől keletre eső Alföldi tanya közelében szintén [HD, 8493.2]; Vajda-lapos [HD, 8493.4]; a Keleti-főcsatorna mentén, a 33-as út hídjánál [TA, 8494.1]; Hortobágy: Máta körül gyakori [MA, 8392.4]. NS: Berettyóúffalu: Csurgó [GG, 8794.4]; Biharnagybajom: Berek [SA, 8793.3]; Malom-köz [SA, 8793.3]; Mély-kút, a Nagybajom-Farkasérköz-csatorna partján [SA, 8793.3]. TKs: Tiszaörs: Pallag-lapos [MA, 8590.2].

704. Rosa corymbifera Borkh. - Herb.: Igmándy (1939): Hajdúnánás: Előhát. Továbbá SZUJKó-LACZA et al. (1982): Hortobágy. Lit.: UJvárosi (1937): Hajdúnánás: Előhát; Soó (1948): Ohat; Nagyhortobágy. Ined.: Ho: Újszentmargita: a Tilos-erdőben [MA, 8292.3].

730. Potentilla recta L. - A Crisicum É-i részén nem gyakori. Herb.: Soó (1932): Egyek: Ohatierdő. Továbbá SzujKó-LACZA et al. (1982): Hortobágy: Darassa, Kunmadaras-Nagyiván, Ohat, Püspökladány: Bodazug. Lit.: MáTHÉ (1933): Ohat-erdő. Ined.: BKk: Berettyóúffalu: 
Korhány-dűlő (Bántó-tanya): felhagyott homokbányában [GG, 8795.1]. DH: Kaba: a vasút mentén [MA, 8693.2].

731. Potentilla heptaphylla L. - A Crisicum-ból szórványosan ismert. A vizsgált térségből nem találtuk adatát. - Ined.: TKs: Tiszaörs: Pallag-lapos [MA, 8590.2].

824. Amygdalus nana L. - A Crisicum-ból szórványos recens adatai ismertek. Herb.: Soó (1932, 1938): Egyek: Ohat; Siroki (1958): Egyek: Ohati-erdő. Lit.: KeRNER (1869): Fegyvernek; TAMÁSSY (1927): Tiszacsege: Ohati erdő; MÁTHÉ (1933): Ohat-erdő; LENDVAI (1999): Nagyiván: Kápolnás-temető; ENDES in MoLNÁR (2005): Hajdúszoboszló: a 4. sz. főút mezsgyéjében; MolNÁR (2005): Karcag: temetőkben. Ined.: DH: Kaba: a vasút mentén [MA, 8693.2]; Nádudvar: a település és Püspökladány közt, a 3405 út közelében, szubspontán [MA, 8692.2].

870. Astragalus cicer L. - Elterjedése a térségben hiányosan ismert. Herb.: Juhász (1933): Debrecen; Újvárosi (1935): Hajdúnánás, Rezes; Soó (1937): Balmazújváros, Hajdúszoboszló, Debrecen; Siroki (1947): Debrecen. Továbbá PAál in SzujKó-LACZA et al. (1982): Hortobágy. Lit.: TAMÁsSY (1927): Hortobágy (puszta); Soó (1934c): Debrecen, Kishegyesi-út; UJvÁrossY (1936): Hajdúnánás; Soó \& MátHÉ (1938): Józsa; Soó (1940): Hajdúszoboszló. Ined.: Ho: Balmazújváros: Magdolna határrészen szikes gyepekbe ékelődő löszgyepben néhány tő [HD, 8393.4].

872. Astragalus austriacus Jacq. - Herb.: SzUjKó-LACZA et al. (1982): Hortobágy. Lit.: Ujvárossy (1936): Hajdúnánás, Rezes; SzUjKó-LACZA et al. (1982): Hortobágy, Szákahalom (sic!); LESKU \& MOLNÁR (2007): Hortobágy (szálkahalmi bemutatóhely degradált löszgyepje). Ined.: Ho: Balmazújváros: Magdolna határrész legelőin a Festuca rupicola által dominált fajgazdag löszgyepekben sokfelé [HD, 8393.4, 8493.2.]; Nagyhegyes: Nyírőlapos határrészen a 33-as út mellett degradált löszgyepfoltban és a Görbe-hodály közelében jó állapotú, fajgazdag löszgyepben [HD, 8493.2].

895. Vicia biennis L. - A faj előfordulási adatainak herbáriumi és irodalmi feldolgozását MoLNÁR V. et al. (2000a) és (előbbit részben pontosítva) SOMLYAY \& BAUER (2013) végezte el. A pontusi-közép-ázsiai fajnak Magyarországon a Tisza és annak mellékfolyói mentéről, illetve a Pesti-síkról származtak előfordulási adatai, jelenleg a Pesti-síkon nincs ismert előfordulási helye. Az utóbbi években a Crisicum-ban többfelé, pl. belvízlevezető csatornák partján is előkerült, főképp a jelen cikkben vizsgált térségen kívül, úgymint Lakitelek, Tiszaalpár, Tiszasas, Tiszaug térségében (SomLYAY \& BAUER 2013), illetve Alsózsolca (TAKÁCS et al. 2013), Görbeháza és Újtikos határában (TAKÁCS et al. 2014b). Herb.: Gulyás \& Sramkó (2009): Püspökladány: Mérges-ér-hát. Lit.: KITAiBEL in JávoRKA (1936): Poroszló és Tiszafüred között; KITAIBEL in KANITZ (1863): Debrecen (megj.: ezt az adatot már Soó \& MÁTHÉ (1938) is kérdőjellel közölte, valójában törlendő, mivel az előző adattal egyezik meg, amint azt SOMLYAY \& BAUER (2013) kimutatta); SimONKAI (1873): Kisújszállás és Karcag: a Hortobágy kanálisának partjain; MÁTHÉ in Soó (1934): az Árkus mentén, feltört talajon (megj.: ezt az előfordulási helyet Soó saját dolgozatában, majd a Tiszántúl flórájában (Soó \& MÁTHÉ 1938) is az Ohati-erdőbe helyezte, de az erdő nem érte el az Árkust. Az ér jelenleg az erdő szélétől K-re, mintegy 900 m-re húzódik); SzABó et al. (1973): Abádszalók: Tisza-ártér holtágai; GuLYÁs (2013): Püspökladány: Mérges-ér-hát. Ined.: TKs: Tiszafüred-Kócsújfalu: Kaparócsárda, a homokbányában, egyetlen példány [MA, 8491.3].

901. Vicia pannonica Crantz subsp. striata (M. Bieb.) Nyman - Elterjedése a térségben hiányosan ismert. Herb.: Kovács (1926): Hencida; Soó (1932): Egyek; Máthé (1935): Püspökladány; Újvárosi (1936): Hajdúnánás; Felföldy (1937): Hortobágy; Soó (1938): Kisújszállás. Lit.: MÁTHÉ (1933): Egyek (Ohat); MolNÁR et al. (2016): Kisújszállás: Nagyerdő. Ined.: Bs: Kismarja: ültetvény nyaras K-i szélén, a Berettyó közelében [GG, 8796.1].

904. Vicia narbonensis L. - Herb.: Kovács (1938): Hencida. Lit.: SimONKAI (1873): Kisújszállás; SIMONKAI (1881): Kismarja, „Pocsaj-felé eső erdő szélein”; MátHé (1933): 
Egyek (Ohati-erdő); Soó \& MátHÉ (1938): Hencida-Gáborján; BoRos (1938): Pocsaj, Törzsökös-erdő. Ined.: Bs: Kismarja: Óriás-part [GG, 8796.2]; vélhetően SIMONKAI (1881) adatával megegyezik.

911. Lathyrus nissolia L. - Herb.: Anon. (é.n.): Kisújszállás; Molnár (2013): Hortobágy (Szálkahalom). Továbbá Soó \& MÁtHÉ (1938): Kisújszállás; SzúJKó-LACZA et al. (1982): Hortobágy. Lit.: THAISZ (1907): Hortobágy (Hortobágyi csárda, Hortobágy-folyó mentén); LESKU \& MoLnÁR (2007): Hajdúszoboszló, Nagykunság keleti része. Ined.: Bs: Mezôpeterd: Reviczki-legelő, a 42-es főút közelében [SG, 8895.2]. Ho: Hortobágy: a falutól északra, a folyó felé néhány [MA, 8492.2]; Máta, a településrészről É felé kivezető Hajcsár-út ás a Hortobágy-folyó között, több száz tő [GG, 8492.4]; Balmazújváros: Magdolna határrészen szikes gyepbe ékelődő löszgyepben néhány tő [HD, 8493.2]. KS: Csökmő: Csík-ér-dűlő [LBA, 8993.3]; Berettyó-töltés [SG, 8993.1]; mentett oldali tölgyes, a Berettyó-töltés mellett [SG, 8993.1]. SzTs: Karcag: Kecskeri-puszta, a Kecskeri-tározótól keletre eső rétekben tízezrek [MA, 8790.2, 8790.4].

921. Lathyrus sylvestris L. - A vizsgált területről szórványos adatai vannak. Herb.: Siroki (1947): Egyek; Siroki (1959): Berettyóújfalu. Lit.: MÁTHÉ (1933): Egyek (Ohati-erdő); Soó \& MÁTHÉ (1938): Hencida-Gáborján; MolNÁR (2005): Nádudvar, Kösely-part; Hortobágy, Szelencés. Ined.: Bs: Kismarja: Nagymarjai-dúlő valamint az Esztár-Nagymarjai mellékcsatorna D-i oldalán, fajgazdag maradvány gyepekben [GG, 8796.2].

922. Lathyrus latifolius L. - Herb.: Soó (1937): Hajdúszoboszló. Lit.: Soó (1948): Egyek (Ohat). Ined.: Bs: Hencida: Berettyó-hullámtér, a Csere-erdőnél [GG, 8796.3]; Ártánd: Proletár-dűlő, a Zomlini-csatorna partján [SG, 8896.2].

936. Ononis spinosiformis Simonk. - KIRÁLY (2009) szerint tisztázandó elterjedésű faj, BARTHA et al. (2015) munkájában nem szerepel. Herb.: Polgár (1915): Hajdúszoboszló. Lit.: KERNER (1868): Hortobágy, Hajdúszoboszló; RAPAICS (1927): Biharugra; Soó \& MátHÉ (1938): Hencida-Gáborján, Molnár (2005): Hajdúszoboszló, repülőtér. Ined.: DH: Hajdúszoboszló: Nyugati-legelőn [MA, 8593.4]. SzTs: Karcag: a várostól délre eső magyarkai legelőkön [MA, 8791.3].

939. Melilotus altissimus Thuill. - A Crisicum-ból szórványos recens adatai ismertek. Lit.: MolnÁR (2005): Tiszaszentimre, Pusztakettős. Ined.: Ho: Balmazújváros: Nagyszik [MA, 8493.2, 8494.1].

959. Trifolium micranthum Viv. - Herb.: Kovács (1939): Gáborján; Siroki (1961): Biharugra; Matus \& Hanyicska (2013): Derecske. Lit.: Soó \& MÁTHÉ (1938): Konyár-Gáborján-Hencida; MolnÁR et al. (2017): Hencida: Csere-erdő. Ined.: Ho: Nagyhegyes: Nyírő-lapos, a Szálkahalmi-erdő mellett [MA, 8493.1]. TKs: Tiszafüred: Péteri-erdő melletti laposok szélein [MA, 8491.3]. Ezek az eddig ismert legészakibb előfordulásai a Kárpát-medencében.

964. Trifolium strictum L. - Herb.: Rapaics (1916): Hortobágy; Siroki (1959): Hortobágy; Siroki (1961): Biharugra. Ined.: Ho: Hortobágy (Máta): Papegyházán szórványos [MA, 8392.4]; Hortobágy: Szatmári-telek [MA, 8492.1]; Karcag: Hegyesbor [MA, 8791.1, 8791.3].

977. Trifolium medium L. - Herb.: Kovács (1932): Gáborján, Berettyó-folyó szélén. Lit.: Kitaibel in KANITZ (1863): Egyek. Ined.: Ho: Nagyhegyes: Nagy-Álomzug északnyugati csücskében, regenerálódó pusztai élőhelymozaikban egy ponton került elő (néhány négyzetméteres foltban van jelen) [HD, 8493.3].

980. Trifolium striatum L. - A Crisicum szikeseinek jellegzetes pillangós növénye, az északi részekről mégis csak szórvány adatai vannak. Herb.: Soó (1932): Egyek (Ohat); Kovács (1937): Gáborján; Siroki (1959): Hortobágy. Ined.: Ho: Egyek: Görbeszék-halom hátján [MA, 8491.1]; Hortobágy (Máta): Papegyházán szórványos [MA, 8392.4]; Hortobágy: Szatmári-telek [MA, 8492.1].

981. Trifolium diffusum Ehrh. - Herb.: Siroki (1959): Egyek, Ohati erdő. Továbbá Soó \& MátHÉ (1938): Hortobágy (Kecskés-puszta); Zsák in Soó \& MÁTHÉ (1938): Püspökladány; 
Debreczy, Fekete, Szújkó-Lacza, Kováts in SzÚjKó-LAczA et al. (1982): Nádudvar (Kocsordsziget). Lit.: KiTAIBEL in KANITZ (1863): Egyek; Hortobágy (puszta). Ined.: Bá: Újszentmargita: horgásztónál és a Tilos-erdő nyugati szélén [MA, 8292.3]. Ho: Hortobágy (Máta): Papegyházán [MA, 8392.4]; Nádudvar: Borzas, a lőtéren belül került régi tanyás földek hátjain [MA, 8592.3]; Nagyhegyes: Nagy-Álomzug északnyugati részén, az állattartó telep közelében, erősen tiport és erősen legeltetett (szarvasmarha) szikes gyepek közé ékelődő apró löszgyep-fragmentumokban [HD, 8493.3]. TKs: Nagyiván: Kis-darvas-halom és annak hátja [MA, 8591.4].

984. Dorycnium herbaceum Vill. - A Crisicum-ból szórványos recens adatai ismertek. Herb.: Matus (2009): Derecske. Lit.: MÁtHÉ (1932): Ohat. Ined.: Bs: Bedô: Proletár-dúlő, a Zomlinicsatorna partján [SG, 8896.2].

986. Lotus angustissimus L. - A Crisicum déli és középső részeiről ismert faj. Az északi részeken csak szórványos recens adatai ismertek. Herb.: Siroki (1959): Hortobágy; Siroki (1961): Biharugra. Lit.: Boros (1938): Ohat; SzujKó-LACZA et al. (1982): Egyek (Ohat). Ined.: Ho: Hortobágy: Kékes [MA, 8492.1]; Kungyörgy [MA, 8492.2]; Zám, Halas, Csirés [MA, 8592.1]; Tiszacsege: Ohati-erdő mellett, Nagymajor felé [MA, 8391.4].

1034. Linum austriacum L. - Herb.: Igmándy (1949): Hajdúdorog; Siroki (1963): Hajdúböszörmény: Zelemér; Anon. (n.d.): Kisújszállás. Továbbá Soó \& MátHÉ (1938): Kisújszállás; Hajdúszoboszló. Lit.: UJvÁRossy (1936): Hajdúnánás; SIMONKAI in Soó \& MÁTHÉ (1938): Hajdúszoboszló; MoLnÁr (2005): Hajdúszoboszló: a vasúti fővonal löszös mezsgyéiben. Ined.: BKk: Berettyóúffalu: Korhány-dűlő (Bántó-tanya): felhagyott homokbányában, több ezer tő [GG, 8795.1]. TKs: Tiszafüred: Kosárhát [MA, 8591.3].

1050. Euphorbia palustris L. - A vizsgált területről szórványos adatai ismertek. Herb.: Soó (1932): Tiszafüred; Kovács (1936): Hencida; Siroki (1948): Egyek. Lit.: RAPAICS (1916): Hortobágy, Herep; Soó (1934b): Tiszafüred; MÁTHÉ (1933): Ohat; MolnÁr (2005): Görbeháza (Bagota). Ined.: Ho: Tiszacsege: Sarkadi-dűlő, müút melletti laposban [LBA, 8392.2]. NS: Püspökladány: Gatály, a Felső-Futak-csatorna partján [SA, 8792.2]; Gatály, múút mezsgyéjében [SA, 8792.2].

1135. Thymelaea passerina (L.) Coss. et Germ. - A Crisicum-ból eddig egy recens adata (KERTÉSZ 2000) ismert. Ined.: Bs: Berettyóúffalu: Kenyeres-föld [SG, 8895.1].

1158. Viola hirta L. - Herb.: Kovács (1937): Gáborján. Lit.: MolNÁR (2005): Egyek (Telekháza), Strázsa-halom. Ined.: Ho: Hortobágy (Máta): Papegyházán [MA, 8392.4]. TKs: Tomajmonostora: Újszentgyörgy felé [MA, 8589.4].

1165. Viola pumila Chaix - A vizsgált területről szórványos adatai ismertek. Herb.: Soó (1933): Sáránd; Soó (1935): Egyek; Kovács (1939): Gáborján. Lit.: BoRos in Soó \& MátHÉ (1938): Püspökladány. Ined.: Ho: Hortobágy: Daru [LBA, 8393.4].

1166. Viola stagnina Kit. - Országosan ritka, eltűnőben levő füzlápi faj. Ined.: Bs: Kismarja: Fertő-nádas [GG, 8796.4]; Nagymarjai-dűlő, mederben [GG, 8796.2].

1175. Elatine alsinastrum L. - A vizsgált területről szórványos adatai ismertek. Herb.: Kovács (1932): Gáborján; Soó (1947): Egyek; Siroki (1948): Egyek; Siroki (1955): Hortobágy; Molnár et al. (1998): Pocsaj; Molnár et al. (2011): Konyár. Lit.: MoEsz (1908): Hortobágy; BoRos (1927): Püspökladány; ÚjvÁRosI (1937): Hajdúnánás; GốRI et al. (1998): Tiszafüred; Molnár V. \& PFeIFFER (1999) és Molnár V. \& GULYÁs (2001): nagyszámú adatot közöltek a vizsgált területről; TAKÁcs et al. (2016): Berettyóújfalu. Ined.: Bs: Berettyóújfalu: Nagy-hídköz, a Berettyó mentett oldali árterén [LBA-MVA, 8795.3]. DH: Földes: Kocsordos, a 42.sz. fóút és a Sárréti-fcst. által körbezárt belvizes szántón [LBA, 8794.1]. Ho: Hortobágy: Pentezug északi részén, rétekben [MA, 8492.2]; Nagy-vókonya, a „Vókonya LIFE” területén [LBA, 8393.3, 8393.1]; Hajdúszoboszló: Angyalháza-Nagyrét [MA, 8492.4]; Nagyiván: Mérgesi-legelő [LBA, 8591.2]; Balmazújváros: Darassa [LBA, 8393.1]. KS: Okány: Majorságitag, belvizes szántón [LBA-MVA, 9194.1]. 
1176. Elatine hungarica Moesz - A vizsgált területről szórványos adatai ismertek. Herb.: Soó (1947): Hortobágy: Máta; Molnár \& Pfeiffer (1998): Pocsaj; Molnár V. et al. (1998): Pocsaj; Molnár V. \& Vidéki (1999): Pocsaj; Molnár \& Pfeiffer (1999): Karcag; Takács (2010): Újtikos-Tiszagyulaháza; Molnár et al. (2011): Konyár. Lit.: Boros (1927): Konyár; UjvÁRosI (1937): Hajdúnánás; Soó (1948) Hortobágy; CSAPODY (1953): Hortobágy; UBRIZSY (1961): Hortobágy; Molnár V. et al. (1999): Pocsaj, Esztár; MolnÁr V. \& PfEIFFER (1999) és MolnÁR V. \& GULYÁS (2001): nagyszámú adatot közöltek a vizsgált területről; JAKAB (2005): Körösladány; MolnÁr (2005): Egyek: Csattag-lapos, Tiszafüred: Hangyás; TAKÁCS et al. (2014b): Hajdúböszörmény; Molnár et al. (2016): Karcag. Ined.: BKk: Berettyóújfalu: Herpály, 47. sz. főút 30,5 km-nél [LBA-MVA, 8795.1]. Bs: Hencida: Gáborján felé vezető műút 11,5 km-nél az út É-i oldalán az árokban [LBA-MVA, 8796.1]. DH: Földes: Kocsordos, a 42.sz. főút és a Sárréti-fcst. által körbezárt belvizes szántón [LBA, 8794.1]; Derecske: Mérges, 47. sz. fóút 23,8 km-nél [LBA-MVA, 8695.3]. Ho: Nagyhegyes-Elep: a majortól délre eső szántókon, nagy kiterjedésben, több évben is [MA, 8493.4]; Hortobágy: Nagy-vókonya, a „Vókonya LIFE” területén [LBA, 8393.3, 8393.1]; Balmazújváros: Nagy-szik, kubikgödör szélén, mangalicák alatt egy kicsiny telep [LBA, 8394.3]. Ks: Körösladány: Siskás-dűlő, 47. sz. fóút 85 km-nél belvizes szántón [LBA-MVA, 8992.4]; Okány: Nagy-Tarcsa, a vasútállomás és a Holt-Sebes-Kőrös közötti belvizes szántón [LBA-MVA, 9193.2]; Majorsági-tag, belvizes szántón [LBA-MVA, 9194.1]; Köröstarcsa: Kettős-Körös 47. sz. főút hídjának ÉK-i lábánál a gát tövében belvizes szántón [LBA-MVA, 9192.1]. SzTs: Karcag: Kecskeri-puszta, a Benetanya alatti laposon [MA, 8790.4]; Magyarka, szántókon [MA, 8791.3].

1178. Elatine triandra Schkuhr - A vizsgált területről szórványos adatai ismertek. Herb.: Siroki (1955): Hortobágy; Löki et al. (2013): Karcag. Lit.: Soó (1948): Hortobágy; MoLNÁR V. \& PfEIfFer (1999): Karcag, Kunmadaras, Szeghalom; Molnár (2005): Kunmadaras, Nagyiván, Hortobágy; Molnár et al. (2016): Karcag. Ined.: Ho: Hortobágy: Nagy-vókonya, a „Vókonya LIFE” területén [LBA, 8393.3]. NS: Nagyrábé: Halom-szer-dűlő [LBA-MVA, 8893.2]; Püspökladány: Hegedűs-hát, csatornában [GG, 8793.1]. Bs: Csökmő: Borsodgyarmati-oldal [LBA-MVA, 8993.2]; SzTs: Karcag: Hattyús, csatornaparton [SG, 8791.3]. TKs: Kunmadaras: Kunmadarasi-puszta, Luca-ér [MA, 8591.4].

1204. Circaea lutetiana L. - Ez a dombvidékeken igen gyakori faj ritkának számít a Crisicum ezen részein. Lit.: MoLNÁR (2005): Újtikos. Ined.: Bs: Biharkeresztes: Körmező-dűlő, ültetvény erdőben [SG, 8896.3].

1220. Epilobium parviflorum Schreb. - A vizsgált területről szórványos adatai ismertek. Herb.: Kállay (1942): Hajdúnánás: Mélyér. Lit.: Soó \& MÁtHÉ (1938): Konyári Sóstó. Ined.: Ho: Balmazújváros: Nagyszik keleti szélén [MA, 8494.1].

1269. Seseli annuum L. - A Crisicum-ból szórványos recens adatai ismertek. Herb.: Kovács (1941): Gáborján: Szigetlegelő; Siroki (1962): Mikepércs, (1978): Tiszacsege, (1983): Hencida. Továbbá SzUjKó-LACZA et al. (1982) szerint Soó illetve Szujkó-Lacza et al.: Ohat. Lit:: MÁthÉ (1933): Ohat-erdő; MÁTHÉ (1939): Hencida: Cserje-erdő; SzujKó-LACZA et al. (1982): Ohat. Ined.: Ho: Hortobágy (Máta): Papegyházán [MA, 8392.4].

1271. Seseli varium Trevir. - Herb.: Siroki (1947): Egyek, Ohati erdő; Siroki (1962): Mikepércs, Szikes talajon. Továbbá Soó \& MÁTHÉ (1938): Ohat, Tiszafüred, Karcag. Lit.: TAMÁSSY in Soó \& MÁTHÉ (1938): Debrecen (Szepes); MolnÁR (2005): Karcag (Vénkerti temető löszgyepjében), Újszentmargita (Kunszög löszhátján), Hortobágy (Szálkahalmi-erdő mellett a Nyírőlaposon), Balmazújváros (108. sz. vasút mentén Nagyhátnál), Hajdúböszörmény-Hajdúvid (Cégényi-út mentén), Hajdúnánás (3501. sz. út mentén a Király-domb kanyarjában); LESKU \& MoLnÁr (2007): Hortobágy. Ined.: Bs: Kismarja: Egresikút környéki gyepek, a volt Rákóczi Tsz. mellett [GG, 8797.1]; Vasad, meder szélén [GG, 8797.1]; a Berettyó töltésén, az országhatár közelében [GG, 8797.1]; a pocsaji Csonta és a Fekete-tanya között, a Berettyó mentén húzódó fajgazdag sztyepréteken [GG, 8796.2, 
8797.1]; az Esztár-Nagymarjai-mellékcsatorna D-i oldalán, fajgazdag maradvány gyepekben [GG, 8796.2]; az országhatáron, a G59-G60 határköveknél [GG, 8797.1]. Bá: Újszentmargita: a Tilos-erdő nyugati szélén [MA, 8292.3]. Ho: Tiszafüred-Kócsújfalu: a Gólyás-lapos és az egykori Piroska-major közötti kis területű löszgyepfoltokban néhány száz tő [HD, 8491.4]. TKs: Tiszafüred-Kócsújfalu: a Kaparó-csárda és a Lapos-halom között kb. félúton a Nagyivánra tartó mủúthoz közel eső keskeny, szántók közötti gyepsáv szegélyén. Néhány tucat [HD, 8491.4].

1275. Oenanthe silaifolia M. Bieb. - A Hortobágyon kifejezetten gyakori mélyebb fekvésű szikes rétekben. Herb.: Soó (1933): Hajdúbagos; Kovács (1936): Hencida: Cserjeerdő; Siroki $(1947,1954,1964)$ : Hortobágy: vasútállomás és halastó környéke. Továbbá Soó \& MátHÉ (1938) szerint Máthé (s.d.): Hencida-Gáborján. Lit.: SImONKAI (1890): Pocsaj és Kismarja; THAISZ (1907): Hortobágy; RAPAICS (1916): Hortobágy; MÁtHÉ (1939): Hencida: Cserje-erdő; BoDRoGKöZY (1965): Hortobágy: Árkus, Máta; SzUjKó-LACZA et al. (1982): Látókép, Nagyiván és Tiszacsege: Cserepes. Ined.: Bs: Berettyóúffalu: Nagy-Revicki-legelő [SG, 8895.2]. Darvas: Borbola-csatorna, a Berettyó töltés mellett [GG, 8993.2]. Nagykereki: Körtélyes [SG, 8897.1]. BKk-Bs: Zsáka: Nagy-kaszáló [SG, 8894.3].

1276. Oenanthe banatica Heuff. - A Crisicum-ban ritka. Lit.: SiMKovics (1881): Kismarjánál, a Pocsaj felé eső erdő szélein. Ined.: KS: Csökmố: mentett oldali tölgyes, a Berettyó-töltés mellett [SG, 8993.1].

1309. Peucedanum carvifolia Vill. - A Crisicum-ban ritka. Ined.: Bs: Nagykereki: Csárdadomb [SG, 8896.2].

1311. Peucedanum officinale L. - A vizsgált területről szórványos adatai ismertek. Herb.: Soó (1931): Hortobágy, (1932): Ohat; Kovács (1936): Hencida: Cserjekaszáló; Ujvárosi (1937): Hajdúnánás: Felsőrét; Kovács (1940): Gáborján: Szigetlegelő; Siroki (1947): Ohati erdő és vasúti töltés mellett; Molnár V. et al. (2011): Berettyóújfalu; Takács (2012): Hajdúnánás, Polgár. Továbbá SzujKó-LACZA et al. (1982) szerint Siroki (1960): „Hármas”; Pintér (1971): Újszentmargita; Szujkó-Lacza et al. (1974): Ohat; Soó \& MátHÉ (1938) szerint Máthé (s.d.): Hencida-Konyár. Lit.: JANKA (1863): Karcag; KERNER (1870): Hortobágy és Karcag; SIMKOVICS (1881): Kismarja és Pocsaj között. RAPAICS (1916): Hortobágy; MAGYAR (1928): Hortobágy és Püspökladány; MÁTHÉ (1933): Ohat-erdő és Újszentmargita; UJVÁRosI (1937): Hajdúnánás: Felsőrét. Továbbá Soó \& MátHÉ (1938) szerint Boros Ádám jegyzeteiben: Tiszabábolna; TAKÁCs et al. (2014b) Hajdúnánás térségéből több helyről jelzi; TAKÁCS et al. (2016): Berettyóújfalu; MoLnÁR et al. (2017): Hortobágy. Ined.: BKk: Berettyóúffalu: Tardi-szik [SG, 8795.3]. Gáborján: Szeles-dúlő [SG, 8795.2]. Hencida: Hosszú-rét [SG, 8796.1]. Kismarja: Dobogó [GG, 8797.1]; Meggyes [GG, 8797.1]; Vasad, meder szélén [GG, 8797.1]; a Kasza-parttól D-re, nagy kiterjedésű legelőn-kaszálón [GG, 8797.1]; az országhatáron, a G60-G63 határkövek között [GG, 8797.1]. Konyár: Hosszú-rét [SG, 8796.1]; Mihályfi-rét-dúlő, földút mellett [HI, 8696.3]. Pocsaj: Dobogó [GG, 8797.1]; Háromágú [GG, 8797.1]. BKk-NS: Bakonszeg: Nagy-Hering, a Nagy-Hering-csatorna mellett [SG, 8894.1]; Nagy-Hering, a Nagy-Hering-csatorna és a műút találkozásánál [SG, 8894.1]. BKk-Bs: Berettyóúffalu: Sziget [SG, 8795.3]; Sziget, földút közelében [GG, 8795.3]. Bs: Berettyóújfalu: Kis-Revicki-legelô, földút mezsgyéjében [GG, 8795.3]. Biharkeresztes: Kisszárcsás-dúlő [SG, 8896.3]; Marján-tag, a 42-es út mellett [GG, 8895.2]. Esztár: Tölgyes erdőfolt szélén, a vasút mellett [GG, 8796.2]; Hencida: Füzes-gát [GG, 8796.3]; Miklósi-erdő, tisztáson az erdő ÉNy-i részén [GG, 8796.3]; Nagy-terebed [GG, 8796.3]. Kismarja: Berettyó jobbparti gyepen, a Fekete-tanya és az országhatár között [GG, 8797.1]; Egresi-kút környéki gyepek, a volt Rákóczi Tsz. mellett [GG, 8797.1]; Fekete-tanya, az ültetvény tölgyes DK-i sarkánál [GG, 8797.1]; Fekete-tanya, az ültetvény tölgyes É-i szegélyén [GG, 8797.1]; a Fekete-tanya É-i szegélyén [GG, 8797.1]; Fóka-part [GG, 8797.3]; Füzes-gát [GG, 8796.3, 8796.4]; Nagymarjai-dúlő [GG, 8796.2, 8796.4]; Pallag-puszta, meder szélén [GG, 
8796.4]; Palló-erdő [GG, 8797.1]; Zálogos, rontottabb nedves gyepen [GG, 8797.3]; a Berettyó töltésén, az országhatár közelében [GG, 8797.1, 8797.3]; a pocsaji Csonta és a Fekete-tanya között, a Berettyó mentén húzódó fajgazdag sztyepréteken [GG, 8796.2, 8797.1]; az Esztár-Nagymarjai mellékcsatorna D-i oldalán [GG, 8796.2]; az országhatáron, a G58-G59 határköveknél [GG, 8797.1]; az országhatáron, a G59-G60 határköveknél [GG, 8797.1]. Nagykereki: Körtélyes [SG, 8896.2]; Országhatár, a G34/2 határkő közelében [SG, 8897.1]. Pocsaj: Csonta [GG, 8796.2]. Ho: Balmazújváros: Nagysziken kevés [MA-LBA, 8494.1]; Virágoskúttól keletre, a 3317 sz. (hajdúnánási) út mellett [MA, 8394.1]; a Keletifőcsatornától keletre a 3316 sz. (debreceni) közút mentén [MA, 8494.1]; Hortobágy felé, a Kishortobágyi csárdától keletre, a 3316 út mentén [MA, 8393.1]. Görbeháza: Bagotánál [MA, 8293.3]; Bagotától délre, a nemzeti park határán [MA, 8293.3]. Hajdúböszörmény: Görbeháza (Bagota) felé, a Hortobágy folyó keleti oldalán [MA, 8293.3]. Hortobágy (Máta): az Epona-nál, a folyó mentén, több száz [MA, 8492.2]; Kékesi-rész, zsombékosban, ez az állomány vélhetőleg azonos a MAGYAR (1928) által védelemre javasolttal [LBA-MA, 8392.3]. Nádudvar-Mihályhalma: a Hortobágy-f. partján a Kösely torkolatnál [LBA, 8592.4]. Ks: Körösladány: Dongó-hát [GG, 9092.2]; Majta [GG, 9092.4]. NS: Biharnagybajom: Berek, a Berek-ér mellett [LBA, 8793.4]. Püspökladány: Ágotapuszta délkeleti sarkában [MA, 8692.3]. Nagyrábé: Csárda-dűlő [HI, 8793.4]; Kis Rábé-puszta [HI, 8793.4]. Sárrétudvari: Malom-köz [SA, 8793.3]. Tetétlen: 42-es fóút mezsgyéje [GG, 8793.2]. TKs: Kunmadaras: volt orosz katonai reptér, a hátsó hangároknál [MA, 8690.1].

1312. Peucedanum alsaticum L. - Herb.: Máthé (1932): Ohat; Soó (1938): Kisújszállás: Öregerdő; Siroki (1947): Ohati erdő. Lit.: MátHÉ (1933): Ohat-erdő és Újszentmargitaierdő; Soó \& MáTHÉ (1938): Kisújszállás; MáTHÉ (1939): Hencida: Cserje-erdő; SzujKó-LACZA et al. (1982): Hortobágy, Zám-puszta. Ined.: Bs: Bakonszeg: Csipszila, a Zsáka-Furtaihatárcsatorna mellett [SG, 8894.2]. Biharkeresztes: 42-es fóút mezsgyéje [GG, 8896.3]; Marján-tag, a 42-es út mellett [GG, 8895.2]. Zsáka: Csipszila, a Zsáka-Furtai-határcsatorna mellett [SG, 8894.2]. BKk: Bakonszeg: Zugi-föld [SG, 8894.2]; Zugi-föld, a Kék-Kálló töltésén [SG, 8894.2]. Ho: Görbeháza: Bagota, a Keleti-fcst. hídjánál [MA, 8293.1]. Balmazújváros: Kis-Hortobágy csárdától K-re, az út mentén [MA, 8393.1]. NS: Püspökladány: Gatály, műút mezsgyéjében [SA, 8792.2]; Hegedűs-hát, műút mezsgyéjében [SA, 8792.2]; a 4 sz. fóút mezsgyéjében, felüljáró közelében [MA, 8692.4]; a 4 sz. fóút É-i oldali mezsgyéjében [MA, 8692.3]. SzTs: Kisújszállás: Nagy-erdő [MA, 8790.3].

1314. Peucedanum cervaria (L.) Lapeyr. - A faj csak a Tiszántúl peremterületeiről ismert (vö. BARTHA et al. 2015). Ined.: BKk: Kismarja: Vasad, meder szélén [GG, 8797.1].

1385. Gentiana pneumonanthe L. - A vizsgált területről származó korábbi adatai távol esnek az itt közölt lelőhelyektől. Herb.: Soó (1935): Hajdúnánás: Előhát. Simon (1947): Tiszacsege. Lit.: IGMÁNDY (1933): Hajdúnánás: Előháti-erdő. MolnÁR (2005): Tiszakeszi, Tiszacsege (Tököslapos). Ined.: Bs: Kismarja: Berettyó jobbparti gyepen, az országhatár közelében [GG, 8797.1]; Füzes-gát [GG, 8796.2, 8796.4].

1391. Nymphoides peltata (S.G. Gmel.) Kuntze - Ez az országosan ritka faj a halastórendszerekben nem ritka. Herb.: Simon (1947): Tiszacsege: Herep; Siroki (1949): Tiszafüred; Soó (1953): Tiszafüred: Örvény-tó; Babai (1961): Tiszafüred; Siroki (1963): Újszentmargita: Selypes csatorna. Továbbá Soó \& MÁTHÉ (1938) szerint: Oláh (s.d.): Karcag. Lit.: JANKA (1864): Biharkeresztes; KERNER (1873): Kisújszállás, Püspökladány, Hortobágy; BORBÁS (1881): a ladányi folyásban Gyomaendrőd és Körösladány közt; RAPAICS (1916): Ohat, „Herep”; Soó (1932): Hortobágyi halastavak csatornáiban; MÁtHÉ (1933): Debrecen: Herep; SZUJKó-LACZA et al. (1982): Kunkápolnási-mocsarak; Kunmadaras: Nagy-Darvas-tó; SZUjKó-LACZA et al. (1982)-nál a „KERNER (1883): Hortobágy” hivatkozás valószínúleg sajtóhiba, a fent is idézett KERNER (1873)-ra vonatkozhat, bár irodalomjegyzékükből ez is hiányzik; Soó \& MátHÉ (1938) és SzUjKó-LACZA et al. (1982) talán tévesen hivatkozik a 
JÁVORKA (1934) által közölt Kitaibel-féle herbáriumi adatra, annak félrevezetően „elnagyolt” lelőhelyleírása miatt („Ad Jákóhalma in Jazygia, in Hortobágy.”). Ined.: Ho: Egyek: Akadémia-halastavak, Vidi-lapos-tó árasztó csatornájában [LBA, 8391.4]; Ohati-halastavak múködő egységein [MA, 8391.4, 8491.2]. Tiszacsege: a Nyugati-főcsatornában bőven, a Halastói-tápcsatorna és az Árkus-bújtató között [GG, 8392.1, 8392.3]

1396. Vincetoxicum hirundinaria Medik. - Herb.: Soó \& MÁTHÉ (1938) szerint Máthé (s.d.): Hencida-Gáborján. Lit.: UJvárossy (1936): Hajdúnánás; MÁtHÉ (1939): Hencida: Cserjeerdő; TAKÁCs et al. (2016): Karcag; MolNÁR et al. (2017): Hortobágy. Ined.: Bs: Kismarja: Nagymarjai-dűlő [GG, 8796.2].

1413. Buglossoides purpurocaerulea (L.) I.M. Johnston - Lit.: IGMÁNDY (1933): Hajdúnánás; Boros (1938): Pocsaj: Törzsökös-erdő. Ined.: Bs: Pocsaj: Tölgyes erdőfoltban, a vasút mellett. Boros (1938) adatának megerősítése [GG, 8796.2].

1420. Echium italicum L. - A Crisicum északi részéről szórványos recens adatai ismertek. Lit.: MoLnÁR (2005): Tiszaderzs-Abádszalók: Úrbéri-legelő. Ined.: DH: Földes: Peres, a múúttól északra a tanya mellett [LBA-VR, 8794.1]. SzTs: Fegyvernek (Szapárfalu): a belterülettől délre eső legelőn [MA, 8789.3]. BKk: Pocsaj: az Ér-fcst. északi oldalában, az országhatáron a löszletörésen, közismert, de eddig publikálatlan adat [Anonym., 8697.3].

1426. Pulmonaria mollissima A. Kern. - Ez a dombvidéken gyakori faj a Crisicum-ból szórvány adatokkal rendelkezik. Herb.: Felföldy (1940): Ohati erdő. Továbbá Soó \& MÁtHé (1938) szerint Máthé (s.d.): Hencida-Gáborján. Lit.: TAMÁssy (1927): Ohati-erdő. MÁtHÉ (1933): Ohat-erdő. Soó \& MÁTHÉ (1938): Pocsaj. MÁTHÉ (1939): Hencida: Cserje-erdő. TALLós \& TóTH (1968): Újszentmargita. Ined.: Bs: Kismarja: Erdő-köz, meder szélében [GG, 8796.2].

1434. Lycopsis arvensis L. - Herb.: Siroki $(1956,1959):$ Hortobágy: vasútállomás; Takács (2012): Hajdúnánás-Tedej: vasúti kőzúzalékon. Lit.: Soó (1968) valószínűleg Siroki herbáriumi adatát közli a Hortobágyról; Molnár V. et al. (2000a): Fegyvernek-Örményes vasútállomás; TAKÁCS et al. (2014b) a fenti, herbáriumi példánnyal dokumentált adatot publikálják Hajdúnánásról. Ined.: Ho: Hortobágy: Juhos-háti erdő szélén [LBA, 8393.3]. TKs: Abádszalók: a település és Tomajmonostora közti kunhalmon [SI, 8589.4]. SzTs: Karcag: Apavára, a vasút mentén [MA, 8791.2] ahonnan azóta ki is pusztult a vasút korszerűsítésekor.

1435. Anchusa barrelieri (All.) Vitman - Herb.: Kovács (1954): Hortobágy; Siroki (1964): Hajdúszoboszló. Lit:: MoLNÁR (2005): Hajdúszoboszló: a 100. sz. vasúti fővonal mezsgyéjén, a Keleti-fő́csatornától nyugatra. Ined.: DH: Hajdúszoboszló: Kéthalom mellett, 2014-ben, szándékosan (tájvédelmi célból) létesített ugaron spontán terjedt! [DB-VO-TP, 8593.3].

1440. Asperugo procumbens L. - Herb.: Soó (1931): Hortobágy; Soó (1932): Ohat: vasút mentén. Ujvárosi (1935): Hajdúnánás: Előhát; Pólya (1947): Hajdúszoboszló. Továbbá Soó \& MÁTHÉ (1938) szerint Oláh (s.d.): Karcag. Lit.: RAPAICS (1916): Hortobágy (Nagyhortobágy); MAGYAR (1930): Püspökladány; MátHÉ (1933): Ohat-erdő. Soó (1934): Hajdúnánás; Soó \& MÁTHÉ (1938): Kisújszállás; MolnÁR et al. (2016): Kisújszállás; MolNÁR et al. (2017): Hajdúnánás. Ined.: Bs-BKk: Berettyóújfalu: Sziget, Sárostókerti "B" csatorna közelében [SG, 8795.3].

1441. Myosotis sicula Guss. - A Tiszántúl egyre több pontjáról ismert, de bizonytalan státuszú taxon. A faj hazai megjelenését Polgár Sándor 1939-es kiskundorozsmai és 1942es sándorfalvai nefelejcs példányainak revíziója alapján közli ŠTĔPANKOVA (1995). A faj déltiszántúli elterjedéséhez JAKAB (2005) közöl adatokat, illetve megjegyzi, hogy az ő általa talált egyedek ugyan megegyeznek ŠTĔPANKOVA (1995) által revideált példányokkal, de eltérnek PIGNATTI (1982) leírásától. Lit.: MoLNÁR (2005): Hortobágy, Fekete-rét, Malomháza, Pentezug, Angyalháza, Alsó-Szelencés. Ined.: Ho: Hortobágy: Nagy-vókonya, a „Vókonya LIFE” területén [MA, 8393.3]; Zám (Halas, Csirés, Kövesháza) [MA, 8592.1]. TKs: 
Kunmadaras: Kunmadarasi-puszta, a Kondás-fertő környéki zsombékosoban [MA, 8591.3]; a Kis-Köves-halom és a Kis-Füves-halom közötti mocsaras laposokban [LBA-MA, 8591.1].

1442. Myosotis caespitosa Schultz - Lit.: Soó (1932): Hortobágy. Ined.: Bs: Hencida: Nagyterebed, mocsárfoltban [GG, 8796.3].

1461. Phacelia tanacetifolia Benth. - A Crisicum-ban szórványos kivadulásai vannak. Ined.: Bs: Kismarja: a Póska-dűlő és a Disznó-kút dúlő között, pusztuló kisparcellás gyümölcsösben [GG, 8797.3].

1466. Callitriche cophocarpa Sendtn. - A Crisicum-ból kevés adata ismert. Herb.: Kovács (1940): Gáborján. Lit.: MoLNÁR (2005): Polgár: Bokorhát. Ined.: Ho: Hortobágy: Nagy-vókonya, a „Vókonya LIFE” területén [MA-LBA, 8393.3]; Balmazújváros: Darassa [LBA, 8393.1].

1477. Teucrium chamaedrys L. - Ez a dombvidéken gyakori faj főleg a Crisicum déli részein ismert. Herb.: Máthé (1931): Egyek: Ohati-erdő. Lit.: MÁTHÉ (1933): Ohat-erdő; MoLNÁR (2005): Hajdúszoboszló; (Debrecen-)Nagymacs; Karcag: Cser-hát. Ined.: Bs: Kismarja: Óriás-part-Középső-szik: a Berettyó bal parti, mentett oldali töltésén [GG, 8796.2]; Ho-Ha: Hajdúnánás: a belterület és a Keleti-fcst. közötti legelő hátjain [MA, 8194.1,3].

1479. Scutellaria hastifolia L. - Herb.: Kovács (1932): Hencida: Cserjeerdő; Soó (1932): Tiszafüred-Poroszló, Hajdúböszörmény (Zelemér); Oláh (1936): Karcag: a füzesgyarmati út mentén; Igmándy (1938): Hajdúnánás: Veresnád; Siroki (1947): Egyek; Siroki (1948): Debrecen: Tócó mentén; Soó (1949): Konyár; Siroki (1955): Tiszafüred. Továbbá SzujKóLACZA et al. (1982): Nagyiván. Lit.: Soó \& MÁTHÉ (1938) szerint közönséges; TALLós \& TóTH (1968): Újszentmargita. Ined.: DH: Berettyóújfalu: Kis-baglyos, a Kék-Kálló mellett [SG, 8795.3]. NS: Biharnagybajom: Mély-kút, a Sárréti-csatorna partján [SA, 8793.3]; Püspökladány: Gatály, a Felső-Futak-csatorna partján [SA, 8792.2]; Udvari-határ-dűlő, a Hamvas-csatorna partján [SA, 8793.1]. SzTs: Karcag: Apavára, a Sándorok-D (3. sz.) mellékcsatorna partján [SA, 8792.1].

1488. Phlomis tuberosa L. - A Hortobágyon gyakoribb, mint a Bihari-síkon vagy a Körösvidék szomszédos részein és a Nagykunságban. Herb.: Máthé (1932): Egyek: Ohat; Soó (1947): Hortobágy: Halastó és Nagyhortobágy között; Siroki (1957): Hortobágy: Paphátierdő; Siroki (1959): Hortobágy: vasúti töltésen. Továbbá Soó \& MátHÉ (1938): Kisújszállás; Szujkó-Lacza et al. (1982): Darassa; Juhoshát; Halastavak; Zám-puszta. Lit.: Soó (1932b): Ohati-erdő; MÁTHÉ (1933): Ohat-erdő; THAISZ (1907): Hortobágy; SZuJKó-LACZA et al. (1982): Halastavak; SZABó in SzUjKó-LACZA et al. (1982): Karcag; Siroki in SzUjKó-LACZA et al. (1982): Hortobágy: Szákahalmi(sic!)-akácos; MoLnÁR (2005): számos adatát közli a következő településekről és pusztákról: Egyek-Telekháza; Egyek-Ohat; Karcag; Nádudvar; Hajdúnánás; Újszentmargita; Újszentmargita-Cserepes; Kungyörgy; HajdúböszörményHajdúvid; Máta; Darassa; Polgár; Tiszafüred; TAKÁcs et al. (2014b): Polgár-GörbeházaHajdúnánás térségéből több pontról közlik; TAKÁcs et al. (2016): Hortobágy (valójában: Tiszafüred): Kaparócsárda. Ined.: Bs: Kismarja: Nagymarjai-dűlő [GG, 8796.2]; Nagykereki: Országhatár, a G34/2 határkő közelében [SG, 8897.1]. Bá: Újszentmargita-Nagyszög: Cigányhát [MA, 8292.1, 8292.2, 8292.3]. DH: Kaba: a vasút mentén [MA, 8693.2]. Ho: Balmazújváros: Darassa, mindenfelé [MA-LBA, 8393.1]; Magdolna északi részén [MA, 8493.2]; Egyek: Tiszafüred felé, a Meggyes-erdőtől délre a megyehatáron [MA, 8491.2]; Görbeháza: Malomzugi-legelő [MA, 8193.1]; Nagybagotánál [MA, 8293.3]; Hortobágy: Daru [LBA, 8393.4]; Árkusmajortól keletre, sok [MA, 8492.3]; a Csécsi-halastavak menti Árkusszakasz keleti oldali gyepen, tömeges [MA, 8492.3]; Hármas, az Árkus és Nyugati-fcst. akvaduktja mellett, utóbbi töltésén [MA, 8492.2]; Kis-vókonya, a Hortobágy-f.-val párhuzamos hátakon többfelé [MA, 8393.3]; Nagy-vókonya, a Kadarcs-karácsonyfokcsatorna torkolata közelében levő hátakon és a Hortobágy-f. mentén, a Fekete-erdő vonalában [MA, 8392.4, 8393.3]; a Nagyvókonya tanyától északkeletre, több háton is [MA, 8393.3]; Pentezug északi részén, a Hortobágy-f. menti hátakon [MA, 8492.4]; Zám, a puszta 
nyugati, sáros-ér menti vonulatain és északnyugat felé, a Kenderátó környékén sokfelé, egészen a Csécsi-halastavakig [MA, 8491.4, 8492.3, 8591.4]; a Nagy-Álomzug-tanyától É-ra, az Alsó-Kadarcs-Kösely-főgyújtő-csatorna közelében, szántómezsgyében [GG, 8493.3]; Nagyhegyes: Nyírő-lapos, a Görbe-hodálytól DNy-ra eső hátacskákon [GG, 8493.1]; Nádudvar: Borzas, a lőtéren belülre került régi tanyás földek hátjain [MA, 8592.3]; Tiszacsege: Nagykecskés, komoly állomány [MA, 8592.3]; Gyökérkút, az Árkus-ér Nyugatifcst. alatti átbújtatója mellett [LBA, 8392.3]; Sólyom-halom [LBA-TG, 8392.1]; Újszentmargita: Dögös-lapos [LBA, 8292.4]; Szandalik-erdő D-i része [LBA, 8393.1]. NS: Földes: Északi-Inács, az Inacs-halmon [GG, 8793.2]. TKs: Egyek: a Csattag-lapos nyugati parti löszgyepekben több, a keleti oldalon kevesebb [MA, 8491.1]; a Sóút északi oldali, nem védett löszgyepben [MA, 8491.1]; Karcag: Kunmadaras felé, az Üllő-laposnál, a Pincéshalomnál korábban már jelzett állománytól keletre, jóval több példány [MA, 8691.1]; Tiszafüred: a Sóút menti hát, a Patkós-csárda közelében [MA, 8491.1]; Tiszaörs: a településtől délre, a 34 sz. fóút mentén [MA, 8590.2].

1505. Leonurus marrubiastrum L. - Herb.: Soó (1932): Egyek: Ohat; Ujvárosi (1935): Hajdúnánás: Mélyér; Siroki (1947): Egyek: Ohat-Pusztakócs; Siroki (1948): Hortobágy, vasúti töltés mentén; Siroki (1948): Máta; Siroki (1949): Hortobágy, a vasúti töltés mellett. Továbbá Soó \& MÁTHÉ (1938): Kisújszállás; SzujKó-LACZA et al. (1982): Újszentmargita. Lit.: MÁTHÉ (1933): Ohat-erdő; TAMÁsSY (1927): Hortobágy; Soó (1934c): Hajdúnánás; Boros in Soó \& MÁTHÉ (1938): Abádszalók; SzujKó-LACZA et al. (1982): Egyek: Ohat; MoLnÁR (2005): Nádudvar: Kösely-meder, Járó-zug; Balmazújváros: Nagy-szik. Ined.: Bá: Egyek: Ohatnagymajor, északra [MA, 8491.2]. Ho: Görbeháza: Nagykapros, a Malomzugi-legelő, a Polgár-Hajdúnánás (3501 sz.) úttól délre [MA, 8193.1,3]; Hortobágy: Pentezug, többfelé [MA, 8492.3, 8492.4]; Zám (Halas, Kövesháza) [MA, 8592.1]; Nagyhegyes: Nyírő-lapos [MA, 8493.1, 8493.2]; Nagyiván: a Sáros-ér mellett, csak néhány [MA, 8591.2]; Nádudvar: Borzas rétjein [MA, 8592.3]; Német-sziget [MA, 8692.1]; Szelencés-puszta, Alsó-Szelencés [MA, 8592.4]; Püspökladány: Ágotapuszta [MA, 8692.3]; Újszentmargita: Tilos-erdő [MA, 8292.3]. NS: Püspökladány: Farkas-sziget [MA, 8692.3]; Mérgesér-hát [MA, 8792.1]. TKs: Kunmadaras: Kunmadarasi-puszta nyugati szélén [MA, 8591.3]; Tiszafüred: a Kilátótanyánál [MA, 8491.1].

1515. Nepeta pannonica L. - A Crisicum-ban igen ritka. Herb.: Simon et al. (1950): Egyek: Ohat-erdő. Továbbá SzujKó-LACZA et al. (1982): Ohat. Ined.: Élh: Létavértes: Partalja, az Érfcst. északi oldalában, az országhatáron a löszletörésen, közismert, de publikálatlan adat [Anonym., 8697.3].

1559. Salvia aethiopis L. - Herb.: Soó \& MÁTHÉ (1938): Kisújszállás. Lit.: Soó \& MátHÉ (1938): Hajdúszoboszló. Ined.: Ho: Balmazújváros: Darassai-erdő [LBA, 8393.1]; Hortobágy: Daru [LBA, 8393.4].

1572. Physalis alkekengi L. - A Crisicum-ban ritka. Herb.: Ujvárosi (1935): Hajdúnánás: Előháti-erdő. Lit.: UJvÁRossY (1936): Hajdúnánás: Előhát; MoLNÁr (2005): Balmazújváros; Karcag. Ined.: NS: Biharnagybajom: Berek, a Berekér-Pusztaéri-csatorna partján [SA, 8793.3].

1591. Lindernia procumbens (Krock.) Philcox - A vizsgált területrôl szórványos adatai ismertek. Herb.: Kovács (1940): Gáborján, Berettyó partján; Siroki (1960): Hortobágy, Hortobágy-Halastó; Molnár V. (1998): Pocsaj, az Ér gátja mellett; Gulyás (2009): Püspökladány, Udvari-határ-dűló, csatornában; Molnár V. et al. (2011): Konyár, Bodzás, belvizes szántón; Gulyás (2012): Bakonszeg, András-halma, halastó-rekonstrukció területén; Löki et al. (2013): Hajdúböszörmény, Hajdúböszörmény-Görbeháza közt, belvizes szántón; Molnár V. (2014): Pocsaj, Ér (Begyűjtött talajból nevelve). Lit.: MolNáR \& PFEIFFER (1999): Abádszalók; Berettyóúffalu; Fegyvernek; Karcag; Pocsaj; Szeghalom; Tiszacsege; BARTHA et al. (2000): Karcag, Barcsis-úti rizsföldek; MoLnÁR \& GuLYÁs (2001): Biharkeresztes; Hajdúszovát; Karcag; Köröstarcsa; Mezősas; Okány; Szeghalom; Tiszafüred; 
MoLNÁR (2005): Nagyiván: Sarkad-ér mente; TAKÁcs et al. (2016): Konyár: Bodzás; MolNÁR et al. (2016): Karcag. Ined.: Bs: Berettyóúffalu: Nagy-hídköz, a Berettyó mentett oldali árterén, belvizes szántón [LBA-MVA, 8795.3]. BKk: Berettyóújfalu: Herpály, 47. sz. főút 30,5 km-nél, belvizes szántón [LBA, 8795.1]. Ho: Újszentmargita: Petenye-ér, belvizes szántón [MA, 8292.3]. NS: Földes: Kocsordos, a 42.sz. főút és a Sárréti-fcst. által körbezárt belvizes szántón [LBA, 8794.1]; Püspökladány: Hegedűs-hát, csatornában [GG, 8793.1].

1592. Lindernia dubia (L.) Pennel - A Crisicum-ban ritka. Előfordulásait Molnár V. et al (2000), majd SCHMOTZER (2015) foglalta össze. Lit.: MolNÁR V. et al. (2000b): Hortobágy: leeresztett halastó medrében a Nyugati-főcsatornánál; Karcag: Magyarka, indiánrizsföldön. Ined.: Ho: Hortobágy: Csécsi-halastavak ivadéknevelő tavának friss iszapján [LBA, 8492.1]; Fényestói-halastavak Nyugati-fcst. melletti ivadéknevelő tavában [LBA, 8492.1]. NS: Nagyrábé: Halom-szer-dülő, pár száz tő [LBA, 8893.2].

1593. Limosella aquatica L. - Herb.: Kovács (1932): Gáborján, Szigetlegelő; Soó (1947): Debrecen: Hortobágy; Siroki (1955): Hortobágy, rizsföldön; Siroki (1975): Hortobágy, Pentezug; Molnár V. (1998): Pocsaj, az Ér gátja mellett. Lit.: KeRnER (1874): Tiszafüred; Soó (1948): Hortobágy; Molnár V. \& PfEIFfER (1999): Tiszacsege: a Cserepes Tsz-tôl Ny-ra; Abádszalók: a Melegh-tanyától D-re; Pocsaj: Poros-tiszta, az Ér hídjánál, a mentett oldalon; MoLNÁR V. \& GuLYÁs (2001): Hajdúböszörmény: 35-ös út mellett; Hajdúszovát: Földes felé; Tiszacsege: Tisza-töltés mellett; Tiszafüred: Tisza-töltés mellett; MoLnÁR (2005): Újtikos: Nagy-erdő; Polgár: szennyvíztelep Ny-i oldala, Pálinkás-lapos; MolNÁR et al. (2016): Karcag. Ined.: BKk: Berettyóújfalu: Herpály, 47. sz. főút 30,5 km-nél [LBA-MVA, 8795.1]. Ho: Újszentmargita: Petenye-ér, belvizes szántón [MA, 8292.3]. SzTs: Karcag: Kecskeri-puszta, a Bene-tanya alatti laposon [MA, 8790.4]; Magyarka, szántókon [MA, 8791.3].

1617. Linaria biebersteinii Besser - A löszös talajú területeken, mezsgyékben akár tömeges is lehet, különösen a Hajdúháton és a Nagykunságban. Herb.: Molnár V. \& Takács (2011): Debrecen: Cora parkolója mellett; Molnár V. \& Takács (2011): Balmazújváros: Kfcs. melletti nyarasban. Továbbá SzujKó-LACZA et al. (1982): Hortobágy; Kunmadaras; Nagyiván, Bürökhalom. Lit.: SimKovics (1878): Hajdúszoboszló: a Kösely nevű vízérnél; BorBÁs (1891): Csökmő; MoLNÁR (2005): általánosan elterjedt a löszös mezsgyékben, különösen a nagykunsági és hajdúháti részen. Ined.: Bá: Egyek: Ohatnagymajornál, több ezer példány [MA, 8491.2]. DH: Hajdúszoboszló: Ebes felé a 4.sz. fóút mentén [MA, 8594.2]; Kaba: a vasút mentén [MA, 8693.2]; Püspökladány: Makkodi-legelő, a Bojár-halom lábánál [LBA-MA, 8692.2]. Ha: Nagyhegyes: 33 főút mentén, már a hajdúháton [MA, 8494.2]. Ha-Ho:, Hajdúböszörmény: a Vidi-ér közelében levő dűlők mezsgyéiben [MA, 8293.2, 8294.1]. Ho: Balmazújváros: a 3321 sz. (hajdúszoboszlói) út mentén, északra a Keleti-főcsatornáig, útkorszerüsítés miatt utóbb javarészt megsemmisült állományok [MA, 8493.1,3]; Magdolna középső hátjain [MA, 8493.2]; Hajdúböszörmény: a Keleti-fcst., a 35. főút és a 3317 út szögletébe eső gyep menti mezsgyékben [MA, 8294.3]; Hajdúszoboszló: AngyalházaMeződűlő, a nemzeti park határán kívüli szántó mezsgyéiben [MA, 8592.2, 8593.1]; Nyugati-legelő [MA, 8593.2, 8593.4]; Hortobágy: Tiszacsege felé, a Nagykecskés-halom környékén [MA-LBA, 8392.3]; Nagyiván: Mérgesi-legelő, Mérges-halom körül több száz tő [LBA-MA, 8592.1]; Nádudvar: Borzas-halom és környéke [MA-LBA, 8592.1]; Kis-Darvas halom, a határárok mezsgyéjében [LBA-MA, 8591.2]; Kút-telek [LBA, 8592.1]; Tiszacsege: Nagykecskés, Nagykecskés-halom és környéke [MA, 8392.3]. NS: Báránd: Nagy-Hangás, földút mezsgyéjében [SA, 8793.1]; Püspökladány: Hosszúhát és Mérgesér-hát [MA, 8792.1, 8792.2, 8792.3]; Gatály, a Felső-Futak-csatorna partján [SA, 8792.2]; Gatály, műút mezsgyéjében [SA, 8792.2]; Hegedűs-hát, műút mezsgyéjében [SA, 8792.2]; Lipót-hát, az Alsó-Futak-csatorna partján [SA, 8792.2]; Mogyorós-dúlő, a K-IX 9. sz. csatorna partján [SA, 8792.2]; Udvari-határ-dúlő, a Hamvas-csatorna partján [SA, 8793.1]; Udvari-határ-dúlő, földút mezsgyéjében [SA, 8793.1]; Sárrétudvari: Földes-Hangás, a Hamvas-csatorna 
közelében [SA, 8793.1]; Földes-Hangás, a Hamvas-csatorna partján [SA, 8793.1]; FöldesHangás, földút mezsgyéjében [SA, 8793.1]; Malom-köz, földút mezsgyéjében [SA, 8793.1]. SzTs: Karcag: Magyarka, a 4 sz. fóút mentén [MA, 8791.3]; Csillag út környéke [MA, 8791.2, 8791.4]; Hegyesbor [MA, 8791.1, 8791.3]; Apavára, a Sándorok-D (3. sz.) mellékcsatorna partján [SA, 8792.1]. SzTs-TKs: Karcag: a tilalmasi út mentén, egész Tilalmasig [MA, 8691.2, 8691.4] TKs: Karcag: Ecse-halom és környéke [MA-LBA, 8591.4]; Kunmadaras: volt orosz katonai reptér [MA, 8690.2]; Tiszafüred: Kaparó-csárdánál [MA, 8491.3].

1624. Digitalis lanata Ehrh. - Országosan terjedőben levő faj, amelynek őshonossága nem bizonyított (Kevey \& Pozsonyi 2003). Lit.: Gulyás in Molnár V. et al (2000): Hajdúböszörmény; MoLNÁR V. \& VIDÉKI in MoLNÁR V. et al. (2000): Konyár Sóstófürdő. Ined.: NS: Biharnagybajom: Csutak-árok-dűlő, több száz tő [BA, 8793.4].

1625. Pseudolysimachion longifolium (L.) Opiz - Herb.: Babai (1961): Tiszafüred; Siroki (1963): Újszentmargita; Sramkó (2011): Abádszalók: Tisza-töltésen. Továbbá Soó \& MáTHÉ (1938): Hencida-Gáborján; Kismarja; SzUjKó-LACZA et al. (1982): Nádudvar, Kocsord-sziget. Lit.: Soó (1934b): Tiszafüred, Tiszacsege; MátHÉ (1933): Ohat-erdő; BoRos (1938): Abádszalók; TALLós \& TóTH (1968): Újszentmargita. Ined.: Bs: Nagykereki: Torma-rész, a vasút mezsgyéjében [SG, 8896.2]; Kismarja: Erdő-köz [GG, 8796.2]; az Esztár-Nagymarjaimellékcsatorna D-i oldalán [GG, 8796.2].

1629. Pseudolysimachion orchideum (Crantz) Wraber - Herb.: Máthé (1932): Újszentmargita; Újvárosi (1937): Hajdúnánás, Nagylegelő. Továbbá Soó \& MÁtHé (1938): Hajdúszoboszló. Lit.: ÚJvárosı (1937): Hajdúnánás, Mélyér; Soó (1934c): Hajdúbagos (erdő); Soó \& MÁTHÉ (1938): Tiszacsege; TAMÁSSY (1927): Hajdú vármegye keleti és déli részében; Tamássy in Soó \& MÁTHÉ (1938): Hortobágy. Ined.: Ho: Nagyhegyes: Vajda-lapos [HD, 8493.4]; Hajdúböszörmény: Görbeháza (Bagota) felé a Hortobágy-f. keleti oldalán [MA, 8293.3]. TKs: Tiszafüred: Zsombori-rész [HD, 8491.4].

1633. Veronica anagalloides Guss. - Herb.: Siroki (1966): Mikepércs. Továbbá SzUjKó-LACZA et al. (1982): Balmazújváros; Hortobágy. Lit.: Soó \& MátHÉ (1938): Hortobágy; Soó (1934c): Debrecen (Téglavető). Ined.: Ho: Hortobágy (Malomháza): Tárkány-ér [MA, 8492.4].

1679. Campsis radicans (L.) Seem. - Ined.: TKs: Tiszafüred: erőteljesen terjed a karcagi vasút mentén [MA, 8390.3].

1715. Sherardia arvensis L. - Ritka, korábban a Dél-Tiszántúlról származott néhány adata. Ined.: BKk: Pocsaj: a Kasza-parttól D-re, felhagyott szántóra vetett gyepen [GG, 8797.1].

1718. Asperula cynanchica L. - Herb.: Kovács (1940): Gáborján, Hármasdűlő; Igmándy (1947): Hajdúnánás. Továbbá Soó \& MÁTHÉ (1938): Hencida-Gáborján. Lit.: TAMÁsSY (1927): Hortobágy; Tamássy in Soó \& MátHÉ (1938): Debrecen: Macs; UJvÁrosI (1937): Hajdúnánás. Ined.: NS: Nagyrábé: Peres [SG, 8893.2].

1725. Galium odoratum (L.) Scop. - Ritka előfordulású a Crisicum területén. Ined.: Ho: Balmazújváros: Magdolna kocsányos tölgyes erdőszármazékban [SA, 8493.2].

1754. Plantago schwarzenbergiana Schur - A vizsgált területről szórványos adatai ismertek. A Hortobágyon szinte összefüggő az elterjedése a Kunkápolnási-mocsártól délre, északra és keletre, ami átnyúlik Borzas, Zám- és Ágota-pusztára is. Másutt szórványosabb, északon majdnem hiányzik. Biogeográfiai szempontból talán északi és déli elterjedési határának adatai az érdekesek. Herb.: Kovács (1927): Hencida; Püspöki (1959): Berettyóúffalu; Siroki (1965): Derecske, (1966): Sárrétudvari, (1975): Hortobágy; Takács (2009): Püspökladány, (2014): Tépe. Lit.: STEFFEK (1864): Püspökladány, MAGYAR (1928): Nagyiván; BORBÁS (1890): Okány, Soó \& MátHÉ (1938): Nádudvar, Szerep, Nagyiván, Hencida, Gáborján, Konyár; SzujKó-LACZA et al. (1982): Hortobágy, Kunmadaras, Nagyiván. Ined.: BKk: Berettyóújfalu: Pap-lapos [SG, 8795.1]; Tardi-szik [SG, 8795.3]; Derecske: Darabos-dúlő [SG, 8795.1]. Bs: Nagykereki: Körtélyes [SG, 8896.2, 8897.1]; Körtélyes, a volt Kossuth Tsz. melletti gyepekben [SG, 8797.3, 8897.1]. DH: Berettyóújfalu: Kis-Andaháza 
[LBA-GG, 8794.2]; Peres-hát [LBA-GG, 8794.1, 8794.2]. Ho: Hortobágy: borsós, a főút mentén [MA, 8492.2]; Máta, a Tonnás-csatornától északra, a Paperi-csatorna mentén [MA, 8392.4]; Karcag: Ágota-Bengecseg [MA, 8691.2, 8692.1]; Nádudvar: Sós-kút-telek [HI, 8592.3]; Sós-kút-telek, földút mellett [HI, 8592.1]. NS: Püspökladány: Mérgesér-hát 4 sz. főút felőli, északi szélén [MA, 8792.1]; Ágotapuszta, Nagykunlapos [MA, 8692.3, 8792.1]; Bakonszeg: Hajzer [HI, 8794.3]; Biharnagybajom: Akasztó-halom-dűlő [SA, 8793.3]; Berek, földút mezsgyéjében [SA, 8793.4]; Korhány, földút mezsgyéjében [SG, 8793.4]; Bihartorda: Hajzer [HI, 8794.3]; Báránd: Dögös-ér-möge [GG, 8793.2]; Nagyrábé: Nagyváradi-legelő [HI, 8793.4]; Nagyváradi-legelő, földút mezsgyéjében [HI, 8793.4]; Tetétlen: Dögös-ér-möge [GG, 8793.2].

1778. Valerianella rimosa Bastard - A Crisicum-ból szórványos recens adatai ismertek. Ined.: Bs: Kismarja: Füzes-gát [GG, 8796.2]; Zálogos, rontottabb nedves gyepen [GG, 8797.3].

1784. Cephalaria transsylvanica (L.) Schrad. - Herb.: Máthé (1931): Debrecen, Nagy Sándor emlék(mű); Soó (1932): Debrecen: Téglagyár; Máthé (1935): Kismarja. Továbbá SzujKóLACZA et al. (1982): Hortobágy. Lit.: TAMÁSSY (1931): Debrecen: a Téglagyár gödreinél és a balmazújvárosi országút mellett; TAMÁsSY (1927): Kisújszállás; Soó \& MÁTHÉ (1938): Mezőpeterd. Ined.: Bs: Biharkeresztes: 42-es főút mezsgyéjében [GG, 8896.3]. DH: Püspökadány: a 4 sz. fóút É-i mezsgyéjében [MA, 8692.3]. SzTs: Karcag: a Déli temetőben, szórványosan sokfelé [MA, 8791.3,4].

1787. Dipsacus fullonum L. - Herb.: Máthé (1937): Váncsod; az úton a település mellett; Kovács (1939): Hencida, Csere-erdő; Kállay (1942): Hajdúnánás, Előháti-erdő szélén; Gondola (1956): Hortobágy. Továbbá Soó \& MÁTHÉ (1938): Kisújszállás. Lit.: RAPAICS (1916): Nagyhortobágy, kaszálón; ÚJvárosi (1937): Hajdúnánás; Soó \& MátHÉ (1938): Hencida-Gáborján, Váncsod; MoLNÁR (2005): Hortobágy, szórványosan többfelé. Ined.: Ho: Nagyhegyes: Nyírő-lapos [MA, 8493.2]. NS: Püspökladány: Ágotapuszta: Nagykunlapos [MA, 8692.3, 87921].

1789. Succisella inflexa (Kluk.) Beck - A Crisicum-ból szórvány adatai ismertek. Lit.: SimonKaI (1881): Biharkeresztes („vízereknél Körös-Tarján és Mező-Keresztes közt”). Ined.: Bs: Mezőpeterd: Kréta, az Ölyvös-csatorna mellett [GG, 8895.2].

1824. Solidago canadensis L. - Lit.: MolNÁR (2005): az invazív aranyvesszők közül ez ritkább, egyes lokalitásokban a Tisza és a Keleti-fcst. mentén előfordul. Ined.: Ho: Balmazújváros: a Nagyszik keleti szélén [MA-LBA, 8493.1].

1829. Aster sedifolius L. - Gyakori faj. Herb.: Máthé (1924): Hortobágy; Soó (1931): Hortobágy; Soó (1932): Egyek: Ohat; Oláh (1933): Karcag; Kovács (1936): Hencida; Ujvárosi (1937): Hajdúnánás: Felsőrét; Kovács (1938): Gáborján: Libalapos; Siroki (1947): Egyek: Ohat, vasúti töltésen; Siroki (1947): Hortobágy: vasútállomás körzetében; Károlyi (1949): Biharnagybajom; Molnár (2001): Kisújszállás: Nagyerdő melletti réteken; Molnár V. et al. (2011): Berettyóúffalu: Tardi-szik. Továbbá Soó \& MÁtHÉ (1938): Karcag; Kisújszállás; Hencida-Gáborján; SzujKó-LACZA et al. (1982): Nádudvar; Ohat; Újszentmargita. Lit.: UJvÁRosI (1937): Hajdúnánás: Felsőrét; MÁTHÉ (1933): Ohat-erdő; Szentmargitai tölgyes erdő; RAPAICS (1916): Hortobágy: mátai kaszáló; Hortobágy keleti partja; MAGYAR (1928): Kishortobágy; SimONKAI (1890): Kismarja; BoRos (1938): Pocsaj: Törzsökös-erdő; Soó (1932): Hortobágy; SIMONKAI in Soó (1925): Nagyrábé; Hajdúszoboszló; JANKA (1863): Karcag; SZABÓ in SzUJKó-LACZA et al. (1982): Bagota; Siroki in SzUJKó-LACZA et al. (1982): Herep; SzUjKó-LACZA et al. (1982): Ohat; Újszentmargita; MátHÉ et al. (1967): Újszentmargita; TALLós \& TóTH (1968): Újszentmargita. Ined.: BKk: Berettyóúffalu: Körtvélyes, kiszáradt ősmederben [SG, 8795.3]; Sziget, Sárostókerti "B" csatorna hídjánál [GG, 8795.3]; Tardi-szik [SG, 8795.3]; Derecske: Köves-úti-rész [HI, 8695.3]; Gáborján: Butyka-dúlő, a Korhány-víz közelében [SG, 8795.2]; Horgas-dúlő [SG, 8795.2]; Madaras-dúlő [SG, 8795.2]; Szeles-dủlő, az Orbán-halom közelében, és másütt is a 
dűlőn [SG, 8795.2]; Hencida: Hosszú-rét [SG, 8796.1]; Kismarja: Berettyó jobbparti gyepen, a Fekete-tanya és az országhatár között [GG, 8797.1]; Berettyó jobbparti gyepen, az országhatár közelében [GG, 8797.1]; Dobogó [GG, 8797.1]; Vasad, meder szélén [GG, 8797.1]; a Kasza-parttól D-re, ültetett nyaras szegélyében [GG, 8797.1]; a pocsaji Csonta és a Fekete-tanya között, a Berettyó mentén húzódó fajgazdag sztyepréteken [GG, 8796.2, 8797.1]; az országhatáron, a G60-G63 határkövek között [GG, 8797.1]; Konyár: Fényes-tódűlő, a Hosszúpályi határmezsgyénél [HI, 8696.3]; Gyopáros-dűlő, árokparton [HI, 8695.4]; Hosszú-rét [SG, 8796.1]; Kis-Horhány-dúlő, a Konyár-Esztár-pocsaji határcsatorna partján [HI, 8696.3]; Nagy-hangás-dűlő, árokparton [HI, 8695.4]; Pocsaj: Csonta [GG, 8796.2]; Három-ágú, az országhatár közelében [GG, 8797.1]; a Kasza-parttól D-re, nagy kiterjedésû legelőn-kaszálón [GG, 8797.1]. Bs: Ártánd: Pap-sziget [SG, 8896.2]; Berettyóúffalu: Fertőoldal [SG, 8895.1]; Kis-Revicki-legelő [GG, 8795.3]; Leckai-terület, a 42-es fóút közelében [GG, 8895.1]; a 42-es fóút mezsgyéjében [GG, 8895.1]; Biharkeresztes: 42-es fóút mezsgyéje [GG, 8895.4, 8896.3]; Kis-szárcsás-dúlő [SG, 8896.3]; Marján-tag, a Fekete-érimellékcsatorna mellett [GG, 8895.2, 8895.4]; Rakottyás-dűlő, vasút mezsgyéjében [SG, 8896.3]; ültetvény erdő szélén, a 42-es fúút mellett [SG, 8896.3]; Esztár: Nyomás-csere, az Esztár-Nagymarjai-mellékcsatorna közelében [GG, 8796.2]; Hencida: Nagy-terebed [GG, 8796.3]; Rákász-dúlő, ültetvény nyaras tisztásán [GG, 8796.1]; Kismarja: Bírák-dűlő [GG, 8796.4]; Egresi-kút környéki gyepek, a volt Rákóczi Tsz. mellett [GG, 8797.1]; Füzes-gát [GG, 8796.1, 8796.2, 8796.3, 8796.4]; Hosszú-dűlő [GG, 8796.4]; Lápis-tó [GG, 8796.4]; Nagy-terebed [GG, 8796.3]; Nagymarjai-dűlő [GG, 8796.2, 8796.4]; Pallag, szikes réten és ültetvény nyarasban is [GG, 8796.4]; a Nagymarjai-dűlő és a Telek-hát között [GG, 8796.4]; az Esztár-Nagymarjai-mellékcsatorna D-i oldalán [GG, 8796.2]; az országhatáron, a G59G60 határköveknél [GG, 8797.1]; Nagykereki: Körtélyes [SG, 8896.2, 8897.1]; Körtélyes, a volt Kossuth Tsz. melletti gyepekben [SG, 8797.3, 8897.1]; Nyárfa-lapos-dűlö, a Dusnokpatak partján [GG, 8796.4]; Országhatár, a G34/2 határkő közelében [SG, 8897.1]; a Dusnok-pataktól É-ra, a kismarjai határmezsgyénél [GG, 8796.4]; az országhatár közelében, a G33-G35 határkövek között [SG, 8797.3, 8897.1]. DH: Derecske: Darabos-dűlő [SG, 8795.1]; Olcsó-kúti-legelő [HI, 8695.3]. Ho: Hortobágy: a Borsósi halastó és a madárkórház között [HI, 8492.2]; Nádudvar: Sós-kút-telek [LBA, 8592.1]. Ks: Körösladány: Dongó-hát [GG, 9092.2]; Majta, a K-IX 9. sz. csatorna partján és másütt is a dủlőn [GG, 9092.4]; Szeghalom: Merán-kis-fás [GG, 9092.2]. NS: Bakonszeg: Hajzer [HI, 8794.3]; Nagy-Hering [SG, 8894.1]; Berettyóújfalu: Csurgó, a 42-es út mellett és a dűlő más részein is [GG, 8794.2, 8794.4]; Kis-Andaháza [LBA-GG, 8794.2]; Kis-baglyos [GG, 8794.4] [SG, 8795.3]; Bihardancsháza: Sás-tó-dűllő [HI, 8793.4, 8794.3]; Biharnagybajom: Akasztó-halom-dűlő [SA, 8793.3]; Berek [SA, 8793.3,] [SA-SG, 8793.4]; Berek, a Berekér-Pusztaéri-csatorna partján [SA, 8793.3]; Elő-gát-köz [SA, 8793.3]; Farkas-ér-köz [SA, 8793.3]; Fertő [SA, 8793.3, 8793.4]; Korhány, mocsárfoltban [SG, 8793.4]; Léka föld, múút mezsgyéjében [HI, 8793.4]; Malom-köz [SA, 8793.3]; Mély-kút, a Nagybajom-Farkasérköz-csatorna partján [SA, 8793.3]; Bihartorda: Hajzer [HI, 8794.3]; Külső-tag [HI, 8794.3]; Báránd: Bacsó [HI, 8793.2]; Belső-bánya, egykori Új Élet Tsz kerítése mellett [HI, 8793.2]; Dögös-ér möge, vasút mezsgyéjében [GG, 8793.2]; Kacskora [HI, 8793.2]; Kincses, a Biharnagybajom melletti csatorna partján [HI, 8793.1]; Földes: Peres, a 42-es út mellett [LBA, GG, 8794.1]; Peres, műút mezsgyéjében [GG, 8794.1]; Nagyrábé: Csata-lapos [SG, 8793.4]; Csárda-dúlő [HI, 8793.4]; Nagyváradi-legelő [HI, 8793.4]; Pap-föld, földút mezsgyéjében [SG, 8893.2]; Sárrétudvari: Malom-köz [SA, 8793.3]; Malom-köz, földút mezsgyéjében [SA, 8793.3]; Tetétlen: 42-es fóút mezsgyéje [GG, 8793.2]; Dögös-ér-möge [GG, 8793.2]; Püspökladány: Kettős-ér-sziget, földút mellett [SA, 8792.1]. SzTs: Karcag: Apavára, a Hortobágy-Berettyó töltésén [GG, 8692.3] [SA, 8792.1]; N11-es öntöző-fcst. partja [HI, 8692.1]; Kunhegyes: Czibak, az Nk.-III. Öntözőfürt fcst. partján [HI, 8689.4]; Püspökladány: Kis-Kun-lapos, a 
Hortobágy-Berettyó töltésén [GG, 8692.3]. TKs: Berekfürdő: Halastó mellett [HI, 8690.2]; Kunhegyes: Akasztóhalom, az Nk.-III. Öntözőfürt fcst. partján [HI, 8689.4]; Tiszafüredi öntöző fcst. partja [HI, 8690.2].

1841. Filago lutescens L. - A vizsgált térségből nem találtuk korábbi adatát. Ined.: Bs: Berettyóúffalu: Kolerás [SG, 8895.1]; Nagy-Revicki-legelő, a 42-es főút közelében [SG, 8895.1].

1843. Filago arvensis L. - Herb.: Soó (1933): Hajdúhadház, Csereerdő; Siroki (1947): Egyek: Óháti erdő; Igmándy \& Igmándy (1948): Püspökladány, Farkasháti-erdő; Igmándy (1948): Nádudvar; Siroki (1949): „Nagyhortobágy, szikes legelőn”, továbbá Soó \& MÁtHÉ (1938): Kunhegyes; Szújkó-Lacza et al. (1982): Hortobágy. Lit.: Soó (1934c): Mikepércs, Hajdúnánás; Soó (1948): Ohati-erdő; Siroki in SzujKó-LACZA et al. (1982): Hortobágy, Nagyiván. Ined.: Bá: Újszentmargita: horgásztónál [MA, 8292.3]. Savanyú homokon társulást képez a Vulpia myuros-al.

1851. Inula helenium L. - A vizsgált térségből nem találtuk korábbi adatát. Ined.: Bs: Nagykereki: Körtélyes [SG, 8897.1].

1856. Inula germanica L. - Herb.: Máthé (1931): Egyek: erdő homokos részén Ohat mellett; Siroki (1975): Hortobágy: Angyalháza, árokparton. Lit.: KITAIBEL in KANITZ (1862): Egyek; MÁTHÉ (1932): Ohat, Hajdúszoboszló; SzujKó-LACZA et al. (1982): Nádudvar; MolnÁR (2005): Löszös talajon sokkal elterjedtebb, mint azt az adatok indikálják. Balmazújváros-Debrecen; Hajdúszoboszló-Ebes; DEÁK et al. (2015): Hencida, Mondró-halom. Ined.: DH: Kaba: a vasút mentén [MA, 8693.2]. Ha: Nagyhegyes: a Hajdú-háton, a Cuca-iskolánál [MA, 8494.2]. NS: Sárrétudvari: Malom-köz, földút mezsgyéjében [SA, 8793.1, 8793.3].

1857. Inula salicina L. - Herb.: Kovács (1936): Hencida, Csere-erdő; Siroki (1947): Egyek: Oháti-erdő, továbbá SZuJKó-LACZA et al. (1982): Ohat. Lit.: MÁTHÉ (1933): Egyek, Ohati-erdő; TALLós \& TótH (1968): Újszentmargita. Ined.: NS: Püspökladány: Mérgesér-hát, Alsókővágói-csatorna [MA, 8792.1].

1861. Pulicaria dysenterica (L.) Bernh. - Herb.: Siroki (1981): Hajdúbagos, vizenyős helyen; Lovas-Kiss \& Takács (2012): Konyár, Konyári Sóstófürdő. Ined.: Bs: Berettyóújfalu: Peresilegelő [LBA, 8895.2].

1899. Achillea nobilis L. - A Crisicum-ból szórványos recens adatai ismertek. Herb.: Soó (1934): Hajdúnánás; Siroki (1949): Hortobágy. Lit.: RAPAICS (1916): Hortobágy; SIROKI in SzUJKó-LACZA et al. (1982): Tiszacsege. Ined.: Ho: Balmazújváros (Darassa): a Hortobágyfolyó nyugati parti hátain [MA, 8393.1]. Tiszacsege: a Kerek-lapostól É-ra, a 600-as csatorna depóniáján bőven [GG, 8392.1]; a Nyugati-főcsatorna depóniáin szórványosan végig a Halastói-tápcsatorna és az Árkus-bújtató között [GG, 8392.1, 8392.3]; a Halastóitápcsatorna K-i depóniáján elég nagy állományok [GG, 8392.2]; Újszentmargita: KosHodály, a Dinnyés-lapostól É-ra, a 7-es öntözőcsatorna depóniáján [GG, 8292.4].

1922. Artemisia annua L. - Lit.: MolnÁR (2005): a Hajdúháton szórványos; Nagyhegyes; Ebes. Ined.: Ho: Balmazújváros: Nagyszik, a város felőli szélén [MA, 8493.1]; Polgár: Kengyelköz, a 36 sz. fóút közelében [MA, 8193.1].

1929. Artemisia pontica L. - A Tiszántúl még feltöretlen szikes gyepjeiben nem ritka. Herb.: Soó (1932): Egyek, (1933): Hajdúbagos; Kovács (1936): Hencida; Siroki (1986): Hortobágy. Lit.: RAPAICS (1916): Hortobágy; MAGYAR (1928): Nádudvar, Püspökladány; SzuJKó-LACZA et al. (1982): Hortobágy; Nagyiván; Egyek (Ohat). Ined.: Bs: Biharkeresztes: 42-es fóút mezsgyéje [GG, 8896.3]; Marján-tag, a 42-es út mellett [GG, 8895.2]; Marján-tag, a Feketeéri-mellékcsatorna mellett [GG, 8895.4]; Kismarja: Meggyes [GG, 8797.1]; Nagymarjai-dűlő, meder szélén [GG, 8796.2]; Országhatár, a G59/1 sz. határkőnél [GG, 8797.1]; a pocsaji Csonta és a Fekete-tanya között, a Berettyó mentén húzódó fajgazdag sztyepréteken [GG, 8796.2, 8797.1]; az országhatáron, a G62 sz. határkőnél [GG, 8797.1]; Nagykereki: az országhatár közelében, a G33-G35 határkövek között [SG, 8897.1]; Pocsaj: Csont, a 
külterület határán Kismarja felé [GG, 8796.2]. Bá: Újszentmargita: Nagyszög [MA, 8292.1, 8292.2]. DH: Földes: Peres, a 42-es út mellett [GG, 8794.1]. Ho: Balmazújváros (Virágoskút): inkább a Keleti-főcsat. keleti oldalán [MA, 8394.1]; Egyek (Ohat): az Ohati-tótól délre és nyugatra a vasútig, többfelé [MA, 8391.4]; Görbeháza (Nagykapros): a Malomzugi-legelő, a Polgár-Hajdúnánás (3501 sz.) úttól délre [MA, 8193.1,3]; Hajdúböszörmény (Bagota): a Hortobágy folyó keleti oldalán [MA, 8293.3]; Hortobágy: Nagy-vókonya [MA, 8393.3]; Nádudvar: Borzas, a Hortobágy folyó körül [MA, 8592.3]; a Hortobágy-Berettyó töltésén és az a melletti hátakon, a Németszigeten [MA, 8692.1]; Újtikos: a Kengyelközi-legelőn, a 36 főúttól délre [MA, 8193.1]. NS: Püspökladány: a Hortobágy-Brettyó hullámterén sok [MA, 8692.3]; Hosszúhát és Mérgesér-hát [MA, 8792.1, 8792.2, 8792.3]; Farkas-sziget [MA, 8692.3]; Gatály, a Felső-Futak-csatorna partján [SA, 8792.2]; Gatály, műút mezsgyéjében [SA, 8792.2]; Hamvas csatorna, a 42-es út mellett [GG, 8693.3]; Hegedűs-hát, műút mezsgyéjében [GG-SA, 8792.2]; Kettős-halom, a Felső-Futak-csatorna partján [GG, 8792.2]; Mogyorós-dűló, A K-9 sz. csatorna partján [GG-SA, 8792.2]; Udvari-határ-dúlő, a Hamvascsatorna partján [SA, 8793.1]; Udvari-határ-dűlő, földút mezsgyéjében [SA, 8793.1]; Vasúti töltés, a Hortobágy-Berettyó közelében [GG, 8692.3]; Berettyóújfalu: Kis-Andaháza, a 42-es út mellett [GG, 8794.2]; Peres, a 42-es út mellett [GG, 8794.1]; Tiszaföldje, a 42-es út mellett [GG, 8794.1]; Biharnagybajom: Berek [SA, 8793.3]; Fertő [SA, 8793.3]; Korhány [SG, 8793.4]; Malom-köz [SA, 8793.3]; Bihartorda: Nagy-Hering, a Pál-foki-csatorna partján [SG, 8894.1]; Báránd: 42-es főút mezsgyéje, vasúti kereszteződésnél [GG, 8793.2]; Hangás, vasúti töltésen [GG, 8693.3]; Nagy-Hangás, földút mezsgyéjében [SA, 8793.1]; Nyársas, a Hamvas-csatorna partján [GG, 8693.3]; Nagyrábé: Tó-Gát, Berekér-Pusztaéri-csatorna partján [SG, 8793.4]; Ásás-oldal, a Mérges-éri csatorna partján [SG, 8894.1]; Sárrétudvari: Földes-Hangás, a Hamvas-csatorna partján [SA, 8793.1]; Földes-Hangás, földút mezsgyéjében [SA, 8793.1]; Malom-köz [SA, 8793.3]; Malom-köz, földút mezsgyéjében [SA, 8793.1, 8793.3]; Tetétlen: 42-es főút mezsgyéje [GG, 8793.2]. SzTs: Karcag: a várostól délre eső, hegyesbori-magyarkai legelőkön [MA, 8791.3]; Hortobágy-Berettyó töltés, Apavára mellett [GG, 8692.3]. TKs: Kunmadaras: Oktalan-lapos [MA, 8590.4]; a volt szovjet reptéren [MA, 8690.2].

1957. Senecio doria Nath. - A Bihari-síkon közúti és dúlő mezsgyékben, jó években gyakori. Herb.: Simon (1947): Debrecen-Mikepércs, vasút mellett; Takács (2012): Hajdúnánás, Vicskus-dűlő; Siroki (1947): Debrecen, vasúti töltésen. Lit.: TAMÁssy (1927): a Nyírség szélén, lösz dombokon, ritkán szikes réteken is; Soó (1934c): Debrecen, Tocómente; ÚJVÁRosI (1937): Hajdúnánás, Rezes; MolnÁr (2005): Ebes, a 4. sz. fóút mentén. NagyhegyesDebrecen. Hortobágy közelében a Pece-ér mentén. Nagyiván, Füredi út végpontja közelében. Ined.: BKk: Konyár: a Derecskei műút 5. sz. km kő [LBA, 8695.4]; Kerek-szik-tó szélén [LBA, 8695.4]. Bs: Biharkeresztes: 42-es főút mezsgyéje [SG, 8896.3]; ültetvény erdő szélén, a 42es füút mellett [SG, 8896.3]; Ártánd: Zavart faluszéli gyepekben, a település K-i szélén [SG, 8896.4]. DH: Debrecen: Tégláskert, Epreskert és a Debreceni Nemzetközi Repülőtér által lehatárolt, még beépítetlen területen lévő kaszálórét szegélyében néhány tő [HD, 8495.4]; Hajdúszoboszló: a várostól keletre, a sínek mentén [MA, 8594.3]. Ha: Balmazújváros: a Keleti-főcsatornától keletre a 3316 sz. (debreceni) közút mentén [MA, 8494.2]; Nagyhegyes: 33 sz. főút mentén, már a hajdúháton [MA, 8494.2].

1965. Echinops sphaerocephalus L. - Herb.: Máthé (1937): Esztár. Ined.: NS: PüspökladányÁgotapuszta: Meggyes-major közelében [MA, 8692.3].

1975. Carduus crispus L. - Herb.: Kovács (1938): Hencida. Lit.: MátHÉ (1936): Berekböszörmény; Soó \& MáTHÉ (1938): Hencida-Gáborján; MoLnÁR (2005): Újtikos: Nagyerdő. Ined.: Bs: Biharkeresztes: ültetvény erdő szélén, a 42-es füút mellett [GG, 8896.3]; Hencida: Miklósi-erdő, holtmederben [GG, 8796.3]; Kismarja: Vagyonváltság, 
meder szélében [GG, 8796.2]; Nagykereki: Csárda-domb [SG, 8896.2]; Körtélyes, a volt Kossuth Tsz. melletti gyepekben [SG, 8897.1].

1984. Cirsium brachycephalum Jur. - A Hortobágyon egyes években szinte mindenhol előfordul szórványosan, vagy akár több tíz hektáros, összefüggő mezőkben is. Az összes állomány egyedszáma ilyenkor százmilliókra tehető. Ilyen évek voltak például 2013 és 2014. Ezzel szemben 2010-ben és 2011-ben alig volt található egy-két példány. A faj azonban délnyugat felé rohamosan elfogy, és a Nagykunság területén gyakorlatilag hiányzik. Herb.: Kovács (1941): Gáborján; Soó (1947): Egyek; Siroki (1949): Hortobágy, (1959): Mezőpeterd, (1962): Mikepércs; Lovas-Kiss \& Takács (2012): Konyár; Takács (2012): Balmazújváros és Görbeháza. Továbbá Soó \& MÁtHÉ (1938) szerint Hortobágy, Kisújszállás, Kunmadaras. Lit.: SIMONKAI (1881): Pocsaj, Kismarja, Nagyrábé; UJvárosI (1937) és Soó (1937): Hajdúnánás; Soó \& MáTHÉ (1938): Hortobágy, Kunmadaras, HencidaGáborján; TAKÁCS et al. (2014b): a vizsgált területről Polgár-Görbeháza-ÚjtikosHajdúnánás térségéből több pontról jelezték; TAKÁcs et al. (2016): Hajdúvid. Ined.: BKk: Berettyóújfalu: Jámbor-földek [LBA, 8795.3]; Peresi-legelő [LBA, 8895.2]; Derecske: Teleklegelő K-i része [LBA, 8695.4]; Liliom-lapos [GG-HI, 8695.3, 8695.4]; Nagy-nyomás, a terület-D-i szegélyén [GG-HI, 8695.4]; Nagy-szik, a Derecskei-Kálló közelében [GG-HI, 8695.4]; mocsárfoltban a Vékony-értől É-ra [GG-HI, 8695.4]; Esztár: Nagy-Rakottyás-tó [HI, 8696.4]; a Kálló-ér mellett [HI, 8696.4]; a Nagy-Szik-tó és a Nagy-Rakottyás-tó között, mocsárfoltban [HI, 8696.4]; a Nagy-Szik-tótól É-ra, mocsár szegélyében [HI, 8696.4]; Gáborján: Horgas-dúlő [SG, 8795.2]; Korhány-dúlő, a Korhány-víz mocsarában [SG, 8795.2, 8795.4]; Szeles-dűlő, az Orbán-halom közelében [SG, 8795.2]; Tépei-fertő-dűlő, mocsárban [SG, 8796.1]; Hencida: Hosszú-rét [SG, 8796.1]; Lasa-lapos [SG, 8796.1]; mocsárfoltban az 1848-as emlékmű mellett [SG, 8796.1]; régi anyagnyerőgödörben a falu É-i szélén [SG, 8796.1]; Hosszúpályi: Folyás-dűlő, mocsárfoltban [GG-HI, 8696.3]; Konyár: Bodzás, mocsárban [GG-HI, 8695.4]; Csikó-lapos [GG-HI, 8696.1, 8696.3]; Folyás-dúlő, mocsárfoltban [GG-HI, 8696.3]; Fényes-tó-dűlő [GG-HI, 8696.3]; Gyopáros-dúlő [GG-HI, 8695.4]; Gyopáros-dűlő, mocsárban a dúlő Ny-i szélén [GG-HI, 8695.4]; Kerek-szik-dűlő [GG-HI, 8695.4]; Kerek-szik-dűlő, mocsárban [GG-HI, 8695.4]; Kígyós-telek [GG-HI, 8695.4]; mocsárfoltban, a Hosszúpályi határmezsgyénél [GG-HI, 8696.3]; Pocsaj: Nagy-legelő, mocsárban [HI, 8696.4, 8796.2]; Szentpéterszeg: Apró-laposok, mocsárban [SG, 8795.2]; Gáp-ér [SG, 8795.2]; Harmadik-róna, a Gáp-érben [SG, 8795.2]; Horgas-ér [SG, 8795.2]; Madaras, mocsárban [SG, 8795.2]; Midó [SG, 8795.2]; Tanyasi-horgas, mocsárfoltban [SG, 8795.2]; Tejfeles, mocsárban [SG, 8795.2]; Sáránd: Csorvás-szik [GG, 8695.2]; Tépe: Békás [GG, 8695.4]; Kálló-köze, mocsárfoltban [GG-HI, 8695.3]; Liliom-lapos [GG-HI, 8695.3]; a Liliom-lapostól Ny-ra lévő mocsárban [GG-HI, 8695.3]. Bs: Biharkeresztes: Marján-tag, a Fekete-éri-mellékcsatorna mellett [GG, 8895.4]; Kismarja: a Fóka-part D-i részén, széles mederben [GG, 8797.3]; mederben, a lokalizációs töltés D-i végénél [GG, 8797.3]; Mezőpeterd: Reviczki-legelő, a 42-es főút közelében [SG, 8895.2]; Nagykereki: Körtélyes [SG, 8896.2, 8897.1]; Körtélyes, a volt Kossuth Tsz. melletti gyepekben [SG, 8897.1]; Országhatár, a G34/2 határkő közelében [SG, 8897.1]. DH: Derecske: Nádas-szik-tó [LBA, 8695.1]; Csorvás-szik [GG, 8695.2]; Fekete-szik [GG, 8695.1, 8695.2]; Köves-úti-rész [GGHI, 8695.3]; Nagy-lapos [GG, 8695.1]; Nagy-legelő, mocsárfoltban [GG-HI, 8695.2]; Nagysziget [GG-HI, 8695.3]; Nagy-szik [GG-HI, 8695.1, 8695.4]; Peres-szik [GG, 8695.2]; Szőlőlapos [GG-HI, 8695.3] [GG, 8695.1]; Szőlő-lapos, múútt mellett [GG-HI, 8695.3]; Vékony-ér [GG-HI, 8695.4]; Vékony-ér mellett [GG-HI, 8695.4]; a Liliom-lapostól Ny-ra lévő mocsárban [GG-HI, 8695.3]; Nagyrábé: Csárda-dúlő, mocsárfoltban [HI, 8793.4]; Nagyváradi-legelő [HI, 8793.4]; Nagyváradi-legelő, mocsárfoltban [HI, 8793.4]; Püspökladány: Mérgesér-hát [MA, 8792.1]. Ho: Balmazújváros: Nagy-szik [LBA, 8494.1]. NS: Bakonszeg: Hajzer, mocsárfoltban [HI, 8794.3]; Győsz-hát, az Ücskő mocsaras részén [SG, 
8895.1]; Kis-Andaháza [GG, 8794.2]; Kis-Csohosz-dűlő [SG, 8795.2]; Körtvélyes, kiszáradt ősmederben [SG, 8795.3]; Nagy-Bócs, Nyártói-csatorna mellett [SG, 8895.1]; Nagy-Revickilegelő [SG, 8895.2]; Nagy-Revicki-legelő, mocsárfoltban [SG, 8895.2]; Szilata-dúlő, mocsárfoltban [SG, 8895.1]; Biharnagybajom: Korhány, mocsárfoltban [SG, 8793.4]; Bihartorda: Hajzer [HI, 8794.3]; Hajzer, mocsárfoltban [HI, 8794.3]; Kerek-tó [HI, 8794.3]; Báránd: Bacsó, mocsárfoltban [HI, 8793.2]; Csorda legelő [HI, 8793.2]; Derecske: Nagynyomás [LBA, 8695.3]. SzTs: Karcag: Kecskeri-puszta, a tarattyó útnál, jó években több tízezer egyed [MA, 8790.2].

1986. Cirsium canum (L.) All. - A Crisicum-ból szórvány adatai ismertek. Lit.: MoLNÁR (2005): Nagyhegyes: Pece-ér mentén sok. Ined.: Ho: Balmazújváros: Nagyszik keleti szélén [MA-LBA, 8493.1]. TKs: Tiszaigar: az Arborétumtól keletre eső gyepen [MA, 8490.4].

1977. Carduus hamulosus Ehrh. - Herb.: Siroki (1947): Hortobágy, (1964): Kaba. Lit.: KiTAIBEL in KANITZ (1863): Balmazújváros; Tuzson (1915): Hortobágy; Boros in Soó \& MÁTHÉ (1938): Karcag; Kunmadaras. Ined.: DH: Hajdúszoboszló: Kéthalom (északi) [MA, 8593.4]. Élh: Létavértes (Cserekert): az Ér-fcst. északi oldalában a löszletörésen, az országhatárhoz közel, jól ismert, de publikálatlan adat [Anonym., 8697.3]; Pocsaj: Hosszúzug; az Ér-fcst. hídja és az országhatár között az Ér-től É-ra levő földváron [MA, 8697.3]. Ho: Hajdúböszörmény: Brassó-halom [MA, 8394.1].

1996. Centaurea solstitialis L. - Herb.: Kovács (1935): Berettyóújfalu; Oláh (1938): Karcag; Igmándy (1948): Püspökladány; Gondola (1952): Újszentmargita, Takács (2009): Püspökladány. Lit.: TAMÁssy (1927): Hortobágy; Soó \& MáthÉ (1938): Karcag, Püspökladány, Berettyóújfalu; SzUJKó-LACZA et al. (1982): Nagyiván; Molnár (2005): Nagyiván; Püspökladány-Ágotapuszta; Karcag. Ined.: Ho: Nádudvar: a Hortobágy-Berettyó töltésén és a vele párhuzamos németszigeti hátakon [MA, 8692.1]. NS: Biharnagybajom: Berek, a település belterületének szélén több száz tő [LBA, 8793.3]; Püspökladány: Mérgesér-hát [MA, 8792.1]; Mérges-ér-hát, a Makkodi-fcst. töltésén [GG, 8692.3]; Kis-Kunlapos, a 4-es főút mezsgyéjében [GG, 8692.3]; Báránd: Belső-bánya, csatorna és a kerítés között [HI, 8793.2]. SzTs: Karcag: a várostól délre eső, hegyesbori-magyarkai legelőkön, elsősorban mezsgyékben [MA, 8791.3]. TKs: Nagyiván: a Bürök-halomtól keletre eső dűlő mentén [MA, 8591.1].

2009. Centaurea arenaria M. Bieb. ex Willd. subsp. borysthenica (Gruner) Dostál - A Crisicum-ból szórvány adatai ismertek. Az alakkör taxonómiai bizonytalanságai is nehezítik az elterjedés tisztázását. Ined.: TKs: Tiszafüred: a várostól délkeletre eső volt gulyalegelő buckáján már kipusztulóban (megszűnt a legeltetés) [MA, 8490.2]; a tiszafüredi belterületen, a karcagi vasút menti buckán még jobb állapotban [MA, 8390.3].

2013. Carthamus lanatus L. - A Hortobágyon eléggé gyakori. Herb.: Soó (1932): Debrecen, Téglavető; Siroki (1955): Hortobágy, állomás útszélén; Sramkó (2014): HortobágySzásztelek. Az Árkus-ér Ny-i partján. Továbbá Soó \& MÁtHÉ (1938): Kisújszállás; Kunhegyes. Lit.: RAPAICS (1916): Nagyhortobágy, „legelőkön bőven nő”; MÁTHÉ in Soó (1934b): Ohat, Az Árkus mentén feltört talajon, Zólyomi in Soó (1942): Kunmadaras, Kunkápolnás; ТótH in SZUJKo-LACZA et al. (1982): Juhoshát; Molnár (2005): Hajdúszoboszló: Angyalháza-Szelencés (a folyóparton megszakításokkal a Rántottásfenéktől a Teke szarváig); Hortobágy, Máta-Papegyháza, Zám-Kövesháza, Árkuspart; Kunmadaras és Karcag, Kunmadarasi-puszta; Köves-fertő, Ecse-zug (Ecse-halom is), C-3-as csatorna töltésén, I. föcsatorna töltésén. Ined.: Ho: Hortobágy: Kadarcs-Karácsonyfokicsatorna partján és töltésén, a torkolathoz közel [MA, 8393.3]; Kungyörgy [MA, 8492.2]. NS: Püspökladány: Ágotapuszta, a Meggyes-major közelében [MA, 8692.3]; Nagykunlapos [MA, 8692.3, 87921]. TKs: Kunmadaras: a Füredi-út mentén [MA, 8591.3].

2030. Scorzonera parviflora Jacq. - Ritka faj, főleg a peremterületeken ismert. Herb.: Siroki (1960, 1965): Mikepércs, nedves, szikes területen; Siroki $(1962,1963)$ : Debrecen, szikes 
réten. Lit.: SzUjKó-LACZA et al. (1982): Hortobágy; MoLNÁR (2005): Nádudvar, Borzason, a megyehatár közelében, a Borzas-erdőtől délre. Ined.: DH: Ebes: a településtől délre húzódó régi Kösely-völgyben [MA, 8594.4]. Ha: Debrecen (Józsa): a Józsai-legelő északi szélén [MA, 8495.2].

2046. Mycelis muralis (L.) Dumort. - A Crisicum ezen részén ritka. Lit.: MolNÁR (2005): Balmazújváros, Karcag, Nádudvar. Ined.: Bá: Tiszacsege: Kunok-erdeje telepített tölgyesben [MA, 8391.2].

2047. Taraxacum bessarabicum (Hornem.) Hand.-Mazz. - Herb.: Soó (1933): Konyár; Igmándy (1937): Hajdúnánás; Siroki (1975): Balmazújváros. Lit.: TuzsoN (1915): Hortobágy; ÚjVÁROSI (1937): Hajdúnánás; Soó \& MÁTHÉ (1938): Konyári Sóstó; SzUJKó-LACZA et al. (1982): Nagyiván; MoLNÁR (2005): Nagyiván; Tiszaderzs-Abádszalók; Görbeháza; Hajdúböszörmény; Nádudvar. Ined.: DH: Ebes: a településtől délre húzódó régi Köselyvölgyben [MA, 8594.4]. Ho: Balmazújváros: Magdolna, a város felőli padkás szikeseken és a csatornánál [MA, 8493.3]; Hajdúböszörmény: Nagy-Bakóhát, a Keleti-fcst., a 35. főut és a 3317 út szögletébe eső szoloncsákos szikeseken, természetes körülmények között [MA, 8294.3]; Hajdúnánás: Tedej felé félúton, kopár szikes laposban [MA, 8194.1]; Hortobágy: Hármas [MA, 8492.1]; Máta, a bemutató-kerekeskútnál [MA, 8492.2]. TKs: Kunmadaras: Kunmadarasi-puszta, a Gyúró-gátnál [MA, 8591.3].

2051. Taraxacum palustre agg. - Lit.: Soó (1932): Hortobágy (Haláp). Ined.: DH: Ebes: a településtől délre húzódó régi Kösely-völgyben [MA, 8594.4].

2052. Chondrilla juncea L. - Lit.: Újvárosi (1937): Hajdúnánás; Soó: 1948: Hortobágy; Molnár (2005): Hajdúszoboszló, a város északi oldalán, a reptéren. Ined.: Bá: Tiszacsege: a Kiskecskés hideglelősi végétől délre eső homoki zártkertben [MA, 8391.2]; TiszacsegeTelekháza: a belterületi háton tömeges [MA, 8391.4]; Újszentmargita: horgásztónál [MA, 8292.3]; Újszentmargita-Nagyszög: Cigányhát [MA, 8292.3].

2059. Crepis pulchra L. - Erősen terjedőben levő faj, különösen zavart élőhelyeken. Ined.: Ha: Hajdúböszörmény: Csorda-legelő, temető mellett [MA, 8394.2]. NS: Biharnagybajom: Berek, földút mezsgyéjében [SG, 8793.4]; Elö-gát-köz [SA, 8793.3]; Korhány, mocsárfoltban [SG, 8793.4]; Karcag: Apavára, a Sándorok-D (3. sz.) mellékcsatorna partján [SA, 8792.1]; Püspökladány: Hegedűs-hát, csatorna partján [SA, 8793.1]; Hegedűs-hát, műút mezsgyéjében [SA, 8792.2]; Kettős-ér-sziget [SA, 8792.1]; Közép-hát [SA, 8792.1]; Középhát, a K-IX 8. sz. csatorna partján [SA, 8792.1]; Közép-hát, az Új-Kővágói-csatorna partján [SA, 8792.1]; Lipót-hát, az Alsó-Futak-csatorna partján [SA, 8792.2]; Nagy-tőke-dúlő [SA, 8792.2]; Nagy-tő́ke-dúlő, a K-IX 9. sz. csatorna partján [SA, 8792.2]; Szőke-sziget, földút mellett [SA, 8792.2]; Udvari-határ-dűlő, a Hamvas-csatorna partján [SA, 8793.1]; Udvarihatár-dűlő, földút mezsgyéjében [SA, 8793.1]. SzTs: Karcag-Karcagpuszta: a 4 sz. főút melletti rét szélén [MA, 8790.4].

2064. Crepis capillaris (L.) Wallr. - Lit.: MoLNÁR (2005): Balmazújváros (Nagyhát). Ined.: DH: Kaba: a cukorgyár alatti szikes legelőkön [MA, 8693.3]. TKs: Nagyiván: a falutól É-ra, a Sáros-ér menti padkás szikeseken [MA, 8591.1].

2129. Stratiotes aloides L. - Herb.: Siroki (1963): Újszentmargita. Lit.: BÁRÁNY (1926): Polgár, Újszentmargita; ÚJvárosi (1937): Hajdúnánás; Soó (1938): Püspökladány; SzUJKó-LACZA et al. (1982): Kunmadaras; MoLNÁR (2005): Tiszafüred-Egyek: Egyek-Pusztakócsi mocsarak; Hortobágy: Árkus. Ined.: Ho: Egyek: az Ohati-halastavak működő egységeinél, övcsatornákban [MA, 8391.4]; Folyás: Nyugati-fcst. [MA, 8292.2]; Hajdúszoboszló: a Kösely Keleti-főcsatornát keresztező szakaszán [MA, 8593.4]; Polgár: a Kengyelközi-tározón [MA-LBA, 8193.1]; Újszentmargita (Bödönhát): Nyugati-fcst. [MA, 8292.4]; Újszentmargita-Nagyszög: Selypes [MA, 8292.2]. TKs: Kunmadaras: Nagyiván felé, a Darvasi-tápcsatornán. Ennyi maradt az egykor hektárokra kiterjedő nagy-darvasi kolokán mezőből. Ezen a termőhelyén a víz nem fagy be, a nyíltvízi állományokat a vadlúdfajok (elsősorban a nyári lúd) legelése-csipkedése 
szoríthatta vissza (Kovács Gábor ex verb.) [MA-LBA, 8591.2]; Tiszafüred: a Fekete-rét Ny-i szélén, a lecsapoló csatornában [LBA-MA, 8491.1, 8491.2, 8491.3].

2137. Triglochin maritimum L. - A Crisicum-ból szórványos recens adatai ismertek. Herb.: Soó (1933): Hajdúbagos, Csapórét; Siroki (1946): Debrecen, a Tócós mentén, árokban; Siroki (1960): Debrecen-Hajdúszentgyörgy, nedves kaszálón. Lit.: SzujKó-LACZA et al. (1982): Hortobágy, „Kékes”. Ined.: Ho: Balmazújváros: Magdolna [LBA, 8493.2].

2155. Ornithogalum brevistylum Wolfner - A Crisicum déli részén általánosan elterjedt, a szélesebb mezsgyéken, közutak, dűlők mentén, a löszgyep-maradványokon és halmokon szinte mindenhol előfordul. A Tiszafüred-Kunhegyesi síkon Kunhegyestôl nyugatra szintén általánosan előfordul. Herb.: Kovács (1928): Váncsod; Oláh (1938): Karcag; Siroki (1965): Mezőtúr, út menti árokban, továbbá Soó \& MÁTHÉ 1938: Kisújszállás; továbbá SzuJKó-LACZA et al. (1982): Egyek-Tiszacsege. Lit.: TAMÁssY (1927): Kisújszállás; MoLnÁR (2005): KarcagKunmadaras vonaltól délre mezsgyékben gyakori, szigetszerű előfordulása van Nagyiván közelében. Ined.: BKk: Berettyóúffalu: Hatöles [GG, 8795.3]. SzTs: Karcag: a Csordalegelő szélén [MA, 8691.3, 8691.4]; Karcag: Apavára, a Hortobágy-Berettyó töltésén [GG, 8692.3]; Apavára, a Sándorok-D (3. sz.) mellékcsatorna partján [SA, 8792.1]. TKs: Karcag, Tilalmas [MA, 8691.2]; Kunmadaras felé, az Üllő-laposnál, a Pincés-halomtól keletre [MA, 8691.1]; Kunmadaras: a volt szovjet reptéren és amelletti közútszakaszon [MA, 8690.2]; Oktalanlapos [MA, 8590.4].

2169. Muscari neglectum Guss. ex Ten. - Herb.: Igmándy (1928): Hajdúnánás, Kajánszik; Ujvárosi (1935): Hajdúnánás, Kajánszik (ez a terület napjainkban Hajdúböszörmény külterületéhez tartozik); továbbá Soó \& MÁTHÉ (1938): Karcag, Kisújszállás, „Babó p.”. Lit.: UjvÁRossy (1936): Hajdúnánás; SzUJKó-LACZA et al. (1982): Nagyiván. Ined.: Ha: Hajdúnánás: a belterület és a Keleti-fcst. közti legelő hátjain [MA, 8194.3].

2186. Allium angulosum L. - Herb.: Soó (1952): Tiszafüred. Lit.: Soó \& MÁtHÉ (1938): Váncsod; SzuJKó-LACZA et al. (1982): Poroszló. Ined.: Bs: Nagykereki: Körtélyes [SG, 8896.2].

2206. Potamogeton trichoides Cham. et Schltdl. - Országosan is ritka, sporadikus elterjedésű faj. Ined.: DH: Berettyóúffalu: Nagy-Andaháza Sárréti-fcst. és a Keleti-fcst. által határolt része [LBA, 8794.2].

2207. Potamogeton pusillus L. em. Fieber. - Országosan is ritka, sporadikus elterjedésű faj. Ined.: Ho: Hortobágy: Nagy-vókonya, a „Vókonya LIFE” területén [LBA, 8393.1, 8393.3].

2208. Potamogeton berchtoldii Fieber - Lit.: MoLNÁR (2005): Hortobágy: Zám. Ined.: DH: Berettyóúffalu: Nagy-Andaháza Sárréti-fcst. és a Keleti-fcst. által határolt része [LBA, 8794.2]. Ho: Hortobágy: Nagy-vókonya, a „Vókonya LIFE” területén [LBA, 8393.3, 8393.1]; Konyár: Kerek-szik-tó [LBA, 8695.4].

2209. Potamogeton crispus L. - Herb.: Kovács (1928): Váncsod; Máthé (1934): Egyek, Soó (1935): Hajdúbagos, (1949): Konyár; Siroki (1947): Hortobágy. Lit.: KeRNER (1877): Tiszafüred; RAPAICS (1916): Ohat; ÚJvárosi (1937): Hajdúnánás; Soó \& MátHÉ (1938): Hortobágy, Püspökladány; Kovács in Soó \& MÁTHÉ (1938): Gáborján; Boros in Soó \& MÁTHÉ (1938): Pocsaj; SzUjKó-LACZA et al. (1982): Kunmadaras. Ined.: Ho: Balmazújváros: a Fecskeréttől nyugatra eső nyílt vizes mocsár Szettyénes és Nyárijárás közt [MA, 8493.1]; Hajdúböszörmény: a Keleti-fcst., a 35. főút és a 3317 út szögletébe eső gyep mocsarába ásott kis gödörben [MA, 8294.3]; Hajdúszoboszló: a Kösely Keleti-fő́csatornát keresztező szakaszán [MA, 8593.4]; Hortobágy: Zám, Halas-fenék nyílt vizes része [MA, 8592.1]; Nagyvókonya, a „Vókonya LIFE” területén [LBA, 8393.3]; Nagyhegyes: a Kadarcs-tóban és leeresztő csatornájában [MA, 8493.4]. TKs: Tiszafüred: Pusztakócsi-mocsarak, SarkadMérges-Sáros-ér medrében [LBA, 8491.3, 8491.4].

2211. Potamogeton gramineus L. - Országosan is ritka, sporadikus elterjedésű faj. A Crisicum-ban a Közép-Tisza és a Körösök mentén volt adata. Lit.: KeRNER (1877): 
Tiszafüred; MolnáR (2005): Görbeházi tározó (Nagy-Kapros); Polgár: Görbe-tó. Ined.: Bá: Újszentmargita: a Gelei-halastóban [MeA, 8292.1].

2212. Potamogeton lucens L. - Herb.: Soó (1932): Tiszafüred; Máthé (1934): Egyek; Kovács (1947): Hortobágy. Lit.: MáTHÉ in Soó (1934a): Egyek (Ohat); Soó (1934b): Hajdúnánás; Boros in Soó \& MÁTHÉ (1938): Tiszafüred-Tiszavalk; Soó \& MÁTHÉ (1938): Tiszalök, Ohat; SzujKó-LACZA et al. (1982): Hortobágy (Sárosér); Kunmadaras. Ined.: Ho: Hortobágy: Nagyvókonya, a „Vókonya LIFE” területén [LBA, 8393.3].

2218. Zannichellia palustris L. - A Crisicum ezen részén egészen ritka. Herb.: Kállay (1942): Hajdúnánás, egy vízzel telt kubikgödör mellett. Továbbá SzujKó-LACzA et al. szerint (1982): Balmazújváros; Hortobágy. Lit.: KERNER (1877): Tiszafüred; MoLNÁR (2005): Karcag: Zádorhíd alatt; Nagyiván: övárok; zámi Halas; Püspökladány: Bodó-rész kubikjai. Véleménye szerint a Hortobágyon egészen ritka. Ined.: Ha: Hajdúdorog: a belterület keleti szélén levő szikes laposon, sajnos, védelme késett, és anyaggödröt nyitottak benne [MA-LBA, 8195.3]. Ho: Nádudvar: Bombatér, a Zádor-lapos egyik bombatölcsérjében [MA, 8592.4].

2249. Monochoria korsakowii Regel et Maack - A faj előfordulása majdnem minden esetben rizshez (Oryza sativa) vagy indiánrizshez (Zizania aquatica) kötődik. Lit.: BARTHA et al. (2000): Hortobágy-Berettyó-főcsatorna (Templom-zug); Karcag, Barcsis-úti rizsföldek; MAJLÁTH (2008): Hortobágy-Berettyó-fõcsatorna, bokrosi szakasz; Kisújszállás határában egy útszéli árokban. Ined.: Ho: Nádudvar: Zöldesi-legelö, mocsárban [HI, 8592.3]. SzTs: Karcag: Kecskeri, a tározótól keletre eső árokban [MA, 8790.2]; Kisújszállás: Varjas, rizsföldi árasztó csatorna medrében [MA-LBA, 8790.4].

2253. Iris spuria L. - A vizsgált térségben szórványos előfordulású faj. Herb.: Siroki (1962): Mikepércs, szikes legelőn, a Tócó-patak mentén. Továbbá SzUjKó-LACZA et al. (1982): Ohat. Lit.: MÁTHÉ et al. (1967): Újszentmargita; MÁTHÉ et al. (1974): Újszentmargita; MolnáR (2005): Görbeháza, Bagotamajortól északra, többfelé és Bagotán; Hajdúböszörmény, Böszörményi-legelő; Hortobágy, Máta északi részén; Hortobágy-Dinnyés, a kónyai út mentén a Karácsonyfoki-csatorna hídjától nem messze; Karcag, Hortobágy-Berettyó hullámtere a Hamvas-torok körül; az apavári 4. sz fóútszakasz mezsgyéje, Tiszacsege, Nagy-Morotva partja és a Morotvaköz. Ined.: BKk: Gáborján: Szeles-dúlő, az Orbán-halom közelében [SG, 8795.2]; Kismarja: a pocsaji Csonta és a Fekete-tanya között, a Berettyó mentén húzódó fajgazdag sztyepréteken [GG, 8797.1]; az országhatáron, a G60-G63 határkövek között [GG, 8797.1]. Bs: Nagykereki: Körtélyes, a volt Kossuth Tsz. melletti gyepekben [SG, 8797.3, 8897.1]; a Dusnok-pataktól É-ra, a kismarjai határmezsgyénél [GG, 8796.4]. Bá: Újszentmargita: Nagyszög [MA, 8292.1, 8292.2]. DH: Berettyóújfalu: Peres-hát [LBA, 8794.1]; Kis-Andaháza [LBA, 8794.2]. Hajdúbagos, Hármas-határ-rész (DerecskeiKálló mente) [HI, 8695.2]. Ho: Hortobágy: Juhos-hát, a Pap-ere és a Hortobágy-f. közötti gyepen [LBA, 8392.4]; Daru [LBA, 8393.4]. NS: Püspökladány: Ágotapuszta, a HortobágyBerettyó hullámtere Hídlábnál, 25 évvel ezelőtt ide telepítettünk néhány gyöktörzset a karcagi Apaváráról, melyekből komoly, sok méterre kiterjedő polikormon származik. Az eredeti termőhely vasút-korszerűsítés során megsemmisült [MA, 8692.3].

2278. Juncus gerardii Loisel. - A Hortobágyon kimondottan ritka. Herb.: Soó (1930): Debrecen, nedves, szikes réten; Soó (1932): Mikepércs, mocsaras-fás területen; Soó (1932): Tiszafüred, a Tisza által elárasztott területen; Poroszló és Tiszafüred között; Máthé (1936): Sáránd, Sáránd és Konyár között; Igmándy (1938): Hajdúnánás, réten Előháton; Siroki (1947): Debrecen, szikesedő, vizenyős réten; Siroki (1947): Hortobágy, mocsaras réten; Siroki (1962): Debrecen, szikes, nedves réten; Siroki (1962): Mikepércs; Siroki (1966): Mikepércs, szikes réten. Továbbá Soó \& MátHÉ (1938): Csökmő. Lit.: RAPAICS (1916): Hortobágy partján; TAMÁssy (1927): Hortobágy; MAGYAR (1928): Nádudvar, Angyalháza; Soó \& MÁTHÉ (1938): Csökmő; SzujKó-LACZA et al. (1982): Balmazújváros; MoLnÁR (2005): Hortobágyon ritka, inkább a keleti szegélyének szódás-szoloncsákos szikesein. Ined.: Ho: 
Balmazújváros: Nagyszik [MA-LBA, 8494.1]; Hajdúszoboszló: Angyalháza, Gólya-telek [MA, 8492.4]; Hortobágy: Zám, Csirés [MA, 8591.2, 8592.1].

2322. Vulpia myuros (L.) C.C. Gmel. - A Crisicum-ból szórványos recens adatai ismertek. A faj savanyú homokon társulást képez a Filago arvensis-szel. Lit.: MolnÁr (2005): Nádudvar: Borzas-Nagy-sziget; Tiszafüred: Péteri-erdő menti hát, Büdös-lapos partján. Ined.: Hortobágy: Kungyörgy [MA, 8492.2]; Püspökladány: Ágotapuszta déli részén, a Gólyafészkes-legelőnél [MA, 8692.3]; Újszentmargita: horgásztónál [MA, 8292.3].

2334. Poa palustris L. - Herb.: Máthé (1932): Újszentmargita, Szentmargita-pusztán nedves réten; Siroki (1955): Tiszafüred, a Tisza partján és nedves réten; Siroki (1970): Debrecen, A kisállomás előtt elterülő, feltúrt területen; Siroki (1985): Hortobágy, Bödönhát, halastó szélén. Lit.: Soó (1934c): Egyek (Ohat, Szentmargita-puszta). Ined.: Ho: Egyek: Ohat felé, Árkus-mente [MA, 8391.4].

2356. Melica transsilvanica Schur - A Crisicum-ból szórványos recens adatai ismertek. Lit.: Soó \& MÁTHÉ (1938): Egyek (Ohat); Hajdúszoboszló; MolnÁr (2005): Hajdúnánás (Tedej). Ined.: SzTs: Karcag: a vasúti fővonal töltése mentén, a város alatt [MA, 8791.4]. TKs: Tomajmonostora: Újszentgyörgy felé [MA, 8589.4].

2384. Bromus benekenii (Lange) Trimen - Ined.: Ho: Tiszafüred: Nyíregyházi-halom [MALBA, 8491.2].

2393. Elymus caninus (L.) L. - Herb.: Máthé (1932): Egyek; Soó (1933): Hajdúbagos, Hosszúpályi. Lit.: MÁTHÉ (1933): Egyek (Ohat); Soó \& MÁTHÉ (1938): Hencida-Gáborján; SzUjKó-LACZA et al. (1982): Újszentmargita. Ined.: Bs: Biharkeresztes: Körmező-dûlő, ültetvény erdőben [SG, 8896.3]. NS: Nagyrábé: Csata-lapos, a műút melletti erdőben [SG, 8793.4]; Füsti-erdő [SG, 8894.1].

2394. Elymus elongatus (Host) Runemark - Herb.: Siroki (1973): Hortobágy (Hármas). Lit.: A magas tarackbúzának eddig négy, egymástól földrajzilag távol eső, őshonosnak tekinthető állománya ismert Magyarországon (BAGI \& SzÉKELY 2006). A fajt először a Hortobágyon találta Siroki Zoltán 1973-ban. Ezt az adatot 1991-ben erősítette meg, és a lelőhely földrajzi helyét később pontosították (MoLnÁR 1996). Ined.: Ho: Hortobágy: Kékes, a „klasszikus”, Siroki Zoltán által talált termőhelyétôl K-re, kb. 2 km-re egy kisebb állomány [MA, 8492.1]; Nagyhegyes: Nyírő-lapos, a Görbe-hodály környéki, főleg attól DK-re eső gyepeken [GG, 8493.1, 2].

2394. Elymus elongatus (Host) Runemark cv. Szarvasi-1 - Herb.: Takács (2012): Görbeháza és Hajdúnánás; Matus \& Rácz (2014): Görbeháza. Lit.: A „cv. Szarvasi-1” energiafü kivadulásokat elsőként NóTÁRI et al. (2011) összegezték (Szolnok-Túri-sík, Bihari-sík, Hajdúság), majd TAKÁcs et al. (2014b) közölték további adatait a vizsgált területről (FolyásPolgár-Görbeháza-Hajdúnánás térségéből). Ined.: BKk: Szentpéterszeg: Horgas-ér [SG, 8795.2]; Madaras [SG, 8795.2]; Nagy-disznós-hát [SG, 8795.2]; Tanyasi-horgas, árok közelében [SG, 8795.2]; NS: Báránd: a kabai (4801 sz.) út mentén [MA, 8693.3]; Csonka-ér, a 42-es út mellett [GG, 8793.2].

2398. Aegilops cylindrica Host - A faj hazai elterjedését TÁBORSKÁ et al. (2015) összegzi. Az ebben a publikációban megjelent herbáriumi, irodalmi és addig közöletlen adatok a következő települések területéről származtak (a vizsgált térségből): Abádszalók, Bucsa, Debrecen, Egyek, Fegyvernek, Hortobágy, Karcag, Kisújszállás, Körösladány, Kunmadaras, Nádudvar, Nagyiván, Sáránd, Szeghalom, Püspökladány, Tiszafüred, Zsáka. Ined.: Bá-Ho: Egyek: a telekházi út mentén az Ohati-erdő vonalában [MA, 8391.4]. Ho: Tiszacsege: a Nyugati-főcsatorna balparti depóniáján, a Kanális-közére vezető híd közelében [GG-TG, 8392.1]. Ho(-NS): Püspökladány: Ágotapuszta déli részén, a Gólyafészkes-legelőnél [MA, 8692.3]; Farkas-sziget [TA, 8692.4]. SzTs: Karcag: a várostól D-re eső, hegyesborimagyarkai legelőkön és csatornapartokon [MA, 8791.1,3]; az 1. sz. csatorna mentén, különösen a Zádor-laposnál [MA, 8691.4]. 
2405. Hordeum jubatum L. - Ez az idegenhonos faj, hasonlóan eredeti észak-amerikai élőhelyéhez, a száraz, instabil, eróziós, törmelékes térszíneket, időszakosan intenzív elöntésű nem szikes és szikes talajokat kedveli. A faj dinamikáját a legeltetés intenzitása erősen befolyásolja, az állattartás általános visszaszorulása miatt sokfelé megjelenik. Első észlelései a vizsgált térségben az 1980-as évekből származnak (MolnáR 2005). Herb.: Molnár V. \& Takács (2011): Balmazújváros: Nagy-szik; Nagy \& Takács (2013): Hajdúnánás: belterület. Lit.: MOLNÁr (2005): Nádudvar; TAKÁCS et al. (2014b): Hajdúnánás és Hajdúdorog. Ined.: DH: Kaba: Pallag-zug, víztározó partján [MA, 8693.4]; Hajdúszoboszló: Gáti (nyugati) legelő, város felőli gödröknél [MA, 8594.3]; Pece-oldali-(északi)-legelő, repülötér, DK-i sarki gödröknél [MA, 8594.1]; Hajdúszovát: a Kösely-fcst. mellett többfelé, a belterületen, és attól K-re levő gödröknél [MA, 8594.4, 8694.2]. Ha: Hajdúnánás: a hajdúdorogi út mindkét oldalán, közvetlenül a város után [MA, 8194.4]; Hajdúdorog: az úffehértói út két oldalán levő kubikgödrökön és természetes laposokon is [MA, 8195.3]; a Hajdúnánásra vezető út D-i oldalán, legelőn [GG, 8194.4]. Ho: Balmazújváros: Nagyszik [LBA, 8394.3, 8494.1]; Hajdúböszörmény: Nagy-Bakóhát, a Keleti-fcst., a 35. főút és a 3317 út szögletébe eső szoloncsákos szikeseken [MA, 8294.3]; Hortobágy: Zám, Tendszer [MA, 8492.3]; Pentezug, Tornyi-domb körül [MA, 8492.4]; Máta déli részén és Mátaközpont [MA, 8492.2]; Nagyhegyes: Nyírő-lapos [MA, 8493.3]; Püspökladány: Ágota-puszta ÉK-i sarkában az Ó-Kösely meder partján [MA, 8692.2]. NS: Biharnagybajom: Farkas-ér-köz [SA, 8793.3]. SzTs: Karcag: téglagyári bányagödrök [MA, 8791.1].

2426. Ventenata dubia (Leers) Coss. - A Hortobágyon helyenként (pl. Ökörföld, Nyírő-lapos) tömeges. Adatait vélhetően nem gyújtik. Herb.: Siroki (1956): Hortobágy. Ined.: BKk: Pocsaj: Kasza-puszta országhatár felé eső részén [LBA, 8797.1]. Bs: Kismarja: az EsztárNagymarjai-mellékcsatorna D-i oldalán, fajgazdag maradvány gyepekben [GG, 8796.2]. Ho: Nagyhegyes: Nyírő-lapos [GG, 8493.1, 2]; Hortobágy: Ökörföld [GG, 8493.1].

2435. Deschampsia caespitosa (L.) P. Beauv. - Ritka a Crisicum-ban. Herb.: Kállay (1943): Hajdúnánás, Kiserdő; Továbbá Soó \& MÁTHÉ (1938): Hencida-Gáborján. Lit.: SZUJKó-LACZA et al. (1982): Újszentmargita. Ined.: Ho: Egyek: Ohati-erdő [MA, 8391.4].

2448. Agrostis gigantea Roth. - SOMLYAY (2009) szerint hazai elterjedése kevéssé ismert. Vélhetően a Hortobágyon elterjedtebb, csak újabban felismert faj. Lit.: Soó in Soó \& MátHÉ (1938): Debrecen, Tócópart. Ined.: Ho: Hajdúböszörmény: Görbeháza (Bagota) felé a Hortobágy folyó keleti oldalán [MA, 8293.3]; Újszentmargita: a Tilos-erdő belső tisztásain [MA, 8292.3].

2456. Calamagrostis canescens (Weber) Roth em. Druce - Herb.: Siroki (1949): Egyek, Borsos \& Simon (1951): Egyek-Tiszacsege; Siroki (1955): Tiszafüred. Lit.: MoLnÁR (2005): Újszentmargita: Tilos-erdő; Ohati-erdő. Ined.: BKk: Berettyóújfalu: Füzes [SG, 8795.3].

2461. Phleum pratense L. - A vizsgált területen előfordulásai nagyrészt adventívek (gyepvetésből kiszabadulva). Herb.: Kovács (1937): Gáborján. Továbbá Soó \& MÁTHÉ (1938): Kisújszállás. Lit.: MoLNÁR (2005): Abádszalók, Úrbéri-legelő. Ined.: DH: Hajdúszoboszló: Nyugati-legelőn [MA, 8593.4, 8594.2].

2473. Stipa capillata L. - A Crisicum-ból szórványos recens adatai ismertek. Herb.: Kovács (1947): Hortobágy: Nagyhortobágy. Továbbá SzUjKó-LACZA et al. (1982): Darassa. Lit.: Kitaibel in KANITZ (1863): Egyek; TAMÁssY (1931): Debrecen: a Nagy Sándor halom meredek lejtőjén; Szabó in SzUjKó-LACZA et al. (1982): Egyek; Nagyiván; MolnáR (2005): Tiszaderzs-Tiszaszentimre: Sor-hát; Tiszafüred: Nagy-Szék-halom és Sóút; Hortobágy: Máta-Darassa határán. Ined.: DH: Földes: Gyilkos-halom [LBA, 8794.2]. Ho: Újszentmargita: Sós-kúti-rét, csatornától északra, löszös magaslaton [LBA, 8293.3]. NS: Földes: Északi-Inács, az Inacs-halmon [GG, 8793.2]. TKs: Egyek (Félhalom): a Csattagtól északra eső háton, nagy területen nő [MA, 8491.1]. 
2494. Crypsis aculeata (L.) Aiton - Herb.: Ujvárosi (1935): Hajdúnánás: Dávidka; Fäller (1937): Hajdúszoboszló, a Kösely mellett; Simon (1947): Mikepércs: Nagyszikes-rét; Kovács (1947): Egyek: Ohat; Siroki (1949): Debrecen: Ondód; Siroki (1962): Debrecen, a repülőtér mellett; Siroki (1975): Konyár: Sóstó; Siroki (1975): Hortobágy; Molnár V. \& Gulyás (2004): Hajdúdorog: a Hajdúnánás felé vezető főút mentén, bal oldalt. Továbbá SzUJKó-LACZA et al. (1982): Balmazújváros; Nagyiván; Nagyiváni-puszta; Sároséri-halom, Zám-puszta; Újszentmargita. Lit.: RAPAICS (1916): Nagyhortobágy, a Hortobágy partján; MAGYAR (1928): Nagyiván, Nádudvar, Balmazújváros; UJvárosI (1937): Hajdúnánás: Dávidka; JANKA (1864): Konyár: Sóstó; (RAPAICS nem közölte Nagyivánról és Nádudvarról, SzuJKó-LACZA et al. (1982) hibásan idézi). Ined.: DH: Berettyóújfalu: Nagy-Andaháza, Sárrétifcst. és a Keleti-fcst. által határolt része [LBA, 8794.2]; Derecske: Morgó [LBA, 8695.3]; Nádas-szik-tó [LBA, 8695.1]; Sáránd: Városréti-legelő [LBA, 8595.4]. Ha: Hajdúdorog: a belterület keleti szélén levő szikes laposon, sajnos védelme késett, és anyaggödröt nyitottak benne [MA-LBA, 8195.3]. Ho: Balmazújváros: Nagyszik [MA-LBA, 8493.2, 8494.1]; Hajdúnánás: Tedej felé félúton, kopár szikes laposban [MA, 8194.1]; Hajdúszoboszló: Angyalháza, Gólya-telek [MA, 8592.2]; Rántottás [MA, 8592.2].

2495. Crypsis schoenoides (L.) Lam. - A C. alopecuroides-nél jóval ritkább. Herb.: Soó (1932): Balmazújváros: kiszáradt szikes tóban; Soó (1933): Konyár: Sóstófürdő; Ujvárosi (1935): Hajdúnánás: Dávidka; Soó (1937): Hajdúbagos: Csapórét; Siroki (1946): Debrecen, szikes talajon; Simon (1947): Mikepércs: Nagyszikes-rét; Siroki (1947): Debrecen, szikes talajon; Siroki (1948): Debrecen, Tócó-menti szikes réten; Siroki (1962): Mikepércs, szikes legelőn; Nagy-Takács (2013): Hajdúnánás: Veres-tenger-dűlő; Sramkó \& Takács (2014): HortobágySzásztelek. Továbbá Soó \& MátHÉ (1938): Karcag. SzujKó-LACZA et al. (1982): Balmazújváros; Hortobágy; Ohat. Lit.: Zsák in Soó \& MÁTHÉ (1938): Karcag; RAPAICS (1916): Nagyhortobágy, a Hortobágy partján; MAGYAR (1928): Nagyiván, Nádudvar, Balmazújváros; UJVÁROSI (1937): Hajdúnánás; Soó (1948): Ohaterdő. (RAPAICS nem közölte Nagyivánról és Nádudvarról, SzujKó-LACZA et al. (1982) hibásan idézi). Ined.: Ho: Balmazújváros: Nagyszik [MA, 8493.2, 8494.1] (Soó 1932-ből származó adatának megerősítése).

2496. Crypsis alopecuroides (Piller et Mitterp.) Schrad. - Lit.: Soó \& MátHÉ (1938) szerint szikeseken közönséges. Ennek ellentmond BARTHA et al. (2015) térképe. Ined.: Ho: Balmazújváros: Nagyszik [MA, 8493.2, 8494.1].

2501. Leersia oryzoides (L.) Sw. - Viszonylag ritka előfordulású. Lit: SIMONKAI (1881): Biharkeresztes (Mezőkeresztes néven), IGMÁNDY in Soó \& MátHÉ (1938): Abádszalók; BARTHA et al. (2000): Karcag, Barcsis-úti rizsföldek; TAKÁcs et al. (2014b): Hajdúnánás: Császár-dűlő - Balázs-dúlő, a K. III. csatorna mentén. Ined.: Ho: Tiszacsege: a Kerek-lapos mellett, a 600-as csatornában, kevés [GG, 8392.1]. NS: Püspökladány: Mogyorós-dúlő, a K-IX 9. sz. csatorna partján [SA, 8792.2]; Nagy-tőke-dúlő, a K-IX 9. sz. csatornában [SA, 8792.2].

2529. Wolffia arrhiza (L.) Horkel ex Wimm. - Lit.: MoLnÁR (2005): Tiszacsege, Kiscserepes. Ined.: Bs: Berettyóúffalu: Rózsa-hát, Nyár-tói-csatorna medrében [LBA, 8895.1]; Kolerás, a Nyártói-csatornában [SG, 8895.1]. Bá: Tiszacsege: a Kiskecskés hideglelősi végétől délre eső kubikgödrökben [MA, 8391.2].

2532. Lemna minuta Kunth - A faj hazai megjelenését MESTERHÁzy et al. (2007) közölte. Azóta egyre több helyen kerül elő, invazívnak is tekinthető. Élőhelyigénye t-k. azonos a rokon L. minor-éval. Ined.: Ho: Berettyóúffalu: Bokoritanya-dűlő, Nyár-tói-csatorna medrében [LBA, 8895.1].

2533. Lemna turionifera Landolt - A faj közelmúltbeli leírását követően (LANDoLT 1975) Európaszerte kimutatták jelenlétét; őshonossága tisztázandó. A faj hazai megjelenését MESTERHÁZY et al. (2008) közölte. Azóta egyre több helyen kerül elő, főleg alföldi területeken. Kedveli az eutróf, sekély felmelegedő kisvizeket, pocsolyákat. Ined.: TKs: 
Tiszafüred: Fekete-rét Ny-i szélén, csatorna mederben [LBA, 8491.2]. DH: Berettyóúffalu: Nagy-Andaháza, Sárréti-fcst. és a Keleti-fcst. által határolt része [LBA, 8794.2].

2541. Typha Iaxmannii Lepech. - Herb.: Siroki (1978): Püspökladány; Kovács (1980): Hortobágyi halastavak; Siroki (1981): Püspökladány. Továbbá SzujKó-LACZA et al. (1982): Kunmadaras. Lit.: BoRos (1960): Kisújszállás; TóTH in SzUjKó-LACZA et al. (1982): Karcag, Zádorhíd; TAKÁcs et al. (2014b): Hajdúnánás: a Polgári út mentén; a K. III főcsatorna mentén. Ined.: Ha: Hajdúdorog: az újfehértói út két oldalán levő kubikgödrökön és természetes laposokon is [MA, 8195.3]. Ho: Balmazújváros: Nagyszik, mocsarakban is [MA, 8493.2, 8494.1]; Egyek: az Ohati-tavaktól nyugatra eső gyep kis gödrében [MA, 8391.4]; Görbeháza: Nagy-kapros, a Nyugati-főcsatornánál [MA, 8193.3]; Hajdúböszörmény: NagyBakóhát, a Keleti-fcst., a 35. főút és a 3317 út szögletébe eső szoloncsákos szikeseken, természetes körülmények között [MA, 8294.3]; Hortobágy: az akadémiai szikeseken [MA, 8492.1]; Kónya, a Kadarcs-Karácsonyfoki-csatorna mellett, a Fekete-erdőtől délre [MA, 8393.3]; Zám, Halas, néhány kisebb állomány [MA, 8492.3]; Nagyhegyes: a 33 út és a nádudvari út kereszteződésénél, árokban [MA, 8493.2]. NS: Püspökladány: Mérgesér-hát, árokban [MA, 8792.1]; Hegedűs-hát, csatornában [SA, 8793.1]; Mogyorós-dűlő, a K-IX 9. sz. csatornában [SA, 8792.2]. SzTs: Karcag: a várostól délre eső, hegyesbori-magyarkai legelők árkaiban [MA, 8791.1, 8791.3]; Kecskeri-puszta, a tarattyó útnál [MA, 8790.2]; a Magyarkai-halastónál, árkokban [MA, 8791.1]; Villogó-csatorna menti mocsárban és zsombékos szikes rétben élt, de az elmúlt években nincsen, vélhetőleg kipusztult [MA, 8791.3]. TKs: Kunmadaras: Kunmadarasi-puszta, a C3-csatornában, mételyfü közelében [MA, 8591.3]; Tiszafüred: Kaparó-csárdánál, homokbánya udvarán [MA, 8491.3].

2549. Schoenoplectus supinus (L.) Palla - Herb.: Soó (1947): Debrecen: Hortobágy, rizsföldön; Siroki (1954): Hortobágy: Borsosi Á. G. rizsföldjén; Siroki \& Simonné (1955): Hortobágy, rizsföldön; Siroki (1955): Hortobágy, rizsföldön; Molnár V. (1998): Pocsaj, az Ér gátja mellett; Gulyás (2009): Püspökladány: Udvari-határ-dúlő; Molnár V. et al. (2011): Konyár: Bodzás; Gulyás (2012): Bakonszeg: András-halma, halastó-rekonstrukció; LovasKiss et al. (2013): Tiszacsege. Lit.: RAPAICS (1916): Nagyhortobágy; Soó (1948): Hortobágy, rizsföldeken; MOLNÁR V. \& PFEIFFER (1999): Hajdúszovát: Bás-halom-dűlő; Nagymező; Abádszalók: a Melegh-tanyától D-re; Tiszafüred: Hagymás-lapos; Fegyvernek: Eperjestanya; Karcag: Magyarka; Püspökladány: Ágota-puszta; Pocsaj; Berettyóúffalu: Herpály; MoLNÁR V \& GuLYÁs (2001): Hajdúböszörmény; Hajdúszovát, Tiszacsege: Tisza-töltés mellett; MolNÁR (2005): Tiszacsege-Egyek; Kunhegyes-Abádszalók; Kunmadaras: Gyúró-kút alatti laposban; TAKÁCS et al. (2014b): Hajdúböszörmény: Magi-dúló; TAKÁcs et al. (2016): Konyár: Bodzás; MolnÁR et al. (2016): Karcag: az Apavári-erdőtől Ny-ra. Ined.: BKk: Berettyóújfalu: Nagyhídköz, a Berettyó mentett oldali árterén [LBA-MVA, 8795.3]; Herpály, 47. sz. főút 30,5 kmnél [LBA-MVA, 8795.1] (MoLNÁR V. \& PFEIFFER (1999) adatának megerősítése). DH: Földes: Kocsordos, a 42.sz. főút és a Sárréti-fcst. által körbezárt belvizes szántón [LBA, 8794.1]. Ho: Hajdúnánás: a 3501 sz. út menti mocsár iszapján, a Keleti-fcst. mellett [MA, 8194.1]. NS: Nagyrábé: Halom-szer-dűlő [LBA-MA, 8893.2]; Kaba: Dögös, a Kaba-Tetétleni-határcsatorna melletti gyeprészletben [LBA, 8693.4].

2552. Schoenoplectus mucronatus (L.) Palla - Herb.: Siroki (1954): Hortobágy, Borsosi Á. G. rizsföldjén; Siroki (1955): Hortobágy, Borsosi Á. G. rizsföldjén; Siroki \& Simonné (1955): Hortobágy, rizsföldön; Anon. (1978): Karcag, rizsföld mellett; Löki et al. (2013): Hajdúböszörmény-Görbeháza. Lit.: CSAPODY (1953): Köröstarcsa. Megjegyezte, hogy csaknem minden rizsben megvan (így tehát vélhetően Tiszafüred: Domoszló; Hortobágy: Máta, Borzas, Ohat, Kónya is!). Boros (1960): Kisújszállás; Molnár V. \& PFEIFFER (1999): Karcag: Magyarka; TAKÁcS et al. (2014b): Hajdúböszörmény: Magi-dűlő; MoLnÁR et al. (2016): Karcag: az Apavári-erdőtől Ny-ra. Ined.: Ha: Hajdúböszörmény: időszakos szikes vízállás a Vidi-ér közelében [MA, 8294.4]. 
2568. Eleocharis acicularis (L.) Roem. et Schult. - Herb.: Kovács (1939): Gáborján, Siroki (1975): Hortobágy; Takács (2010): Újtikos; Sramkó (2011): Polgár. Lit:: Soó \& MátHÉ (1938): Kisújszállás; SzUJKó-LACZA et al. (1982): Balmazújváros; Hortobágy; MoLNÁR (2005): Tiszafüred; TAKÁcs et al. (2014b): Újtikos. Ined.: Ho: Újszentmargita: a Szandalik-erdő Ny-i szélén [LBA, 8392.2].

2572. Eleocharis uniglumis (Link) Schult - Lit.: IGMÁNDY in ÚJVÁROSI (1937): Hajdúnánás (Kajánszik); Soó (1934b): Hortobágy; Soó \& MátHÉ (1938): Kunmadaras, Karcag, Nádudvar. Ined.: DH: Sáránd: Városréti-legelő [LBA, 8595.4].

2575. Eleocharis mamillata H. Lindb. - Lit.: Soó \& MÁtHÉ (1938): Hotobágy, KonyárGáborján, Kisújszállás; MoLnÁR (2005): Nagyiván; Hajdúszoboszló; Karcag. Ined.: Ho: Hajdúszoboszló: Angyalháza, Égett-telek [MA, 8492.4]; Hortobágy (Malomháza): Tárkány-ér [MA, 8492.4]. TKs: Kunmadaras: Kunmadarasi-puszta, Bogárzó-Luca [MA, 8591.3, 8591.4].

2577. Cyperus pannonicus Jacq. - Herb.: Soó (1933): Konyár; Simon (1947): Mikepércs; Siroki (1975): Balmazújváros; Molnár \& Gulyás (2004): Hajdúdorog. Lit.: IGMÁNDY (1933): Hajdúnánás; Soó (1934c): Konyári-Sóstó. Ined.: Ha: Hajdúdorog: a belterület keleti szélén levő szikes laposon, sajnos, védelme késett, és anyaggödröt nyitottak benne [MA, 8195.3].

2580. Cyperus difformis L. - Korábban a Karcag környéki rizsföldeken, de mocsarakban is többfelé élt a rizstermesztés fénykorában, most eltűnőben. Herb.: Siroki (1958): Hortobágy, Borsósi Állami Gazdaság; Fazekas (1960): Kisújszállás, rizsföldek. Lit.: SzuJKó-LACZA et al. (1982): Hortobágy; MoLnÁR (2005): Karcag: Kecskeri-puszta, Tarattyó út mente, kihalt; MolnÁR et al. (2016): Karcag: az Apavári-erdőtől Ny-ra. Ined.: SzTs: Karcag: Kecskeripuszta, a Bene-tanya alatti laposon [MA, 8790.2].

2606. Carex disticha Huds. - A Crisicum-ból szórványos recens adatai ismertek. Lit.: MoLNÁR (2005): Tiszafüred: Hagymás-lapos. Ined.: Ho: Újszentmargita: a Dinnyés-lapos É-i szélén a 7es öntözőcsatorna torkolatánál [GG, 8292.4]. TKs: Egyek: a félhalmi út mentén [MA, 8491.1].

2610. Carex elata All. - A Crisicum-ból szórványos recens adatai ismertek. Herb.: Soó (1935): Hajdúnánás, (1938) Egyek. Lit.: MátHÉ (1933): Egyek (Ohat). Ined.: BKk: Berettyóújfalu: Füzes [SG, 8795.3]; Pocsaj: Háromágú medrében [MA, 8797.1]. Bs: Bedő: Pap-rét, mocsárban a Bedő-Káptalan-csatorna mellett [SG, 8896.2]; Berettyóúffalu: Nagy-Revickilegelő, mocsárfoltban [SG, 8895.2] Kismarja: Berettyó északi oldalán levő elhagyott mederben [MA, 8796.2]. Bá: Újszentmargita: Tilos-erdő [MA, 8292.3].

2613. Carex buekii Wimm. - A vizsgált területről nem találtuk adatát. Ined.: Bs: Berettyóúffalu: Berettyó meder [GG, 8795.3]; Berettyó meder, a Berettyó holtmedermaradványa közelében [SG, 8795.3]; Malom-füzes [SG, 8795.3]; Darvas: Gógánlegelő, a Berettyó töltés mellett [GG, 8993.2]; Hencida: Berettyó-hullámtér, a Csere-erdőnél [GG, 8796.3]; Nagykereki: Szentpéter-dűlő, mederben [SG, 8896.2]; Szentpéterszeg: Berettyó-part, a Mályvás-dúlőnél [SG, 8795.4]; Váncsod: Berettyó-part, a Szénás-dűlőnél [SG, 8795.4]; Zsáka: Berettyó hullámtere [SG, 8894.2]; Csipszila [SG, 8894.2]; Csipszila, a Berettyó töltésén [SG, 8894.2]; Ártánd: Csíkos-ér, a település K-i szélén [SG, 8896.4]; Papsziget, a Zomlai-csatornában [SG, 8896.2]; Proletár-dúlő, a Zomlini-csatorna partján [SG, 8896.2]. SzTs: Karcag: Apavára, a Sándorok-D (3. sz.) mellékcsatorna partján [SA, 8792.1].

2633. Carex pseudocyperus L. - Lit.: TAKÁCS et al. (2014b): Polgár-Görbeháza-Hajdúnánás térségéből több pontról jelezték. Herb.: Takács (2012): Hajdúnánás. Ined.: BKk: Bakonszeg: Zugi-föld, a Kék-Kállóban [SG, 8894.2]. Bs: Berettyóúffalu: Nagy-Bócs, a Nyártóicsatornában [SG, 8895.1]; Biharkeresztes: Kis-szárcsás-dűlő, mocsárfoltban [SG, 8896.3]. Ho: Balmazújváros: a Sziki-tó nádasaiban és partján bőven [GG-NT, 8394.3]. Hajdúszoboszló: a Kösely-fcst. Keleti-főcsatornát keresztező szakaszán [MA, 8593.4]; Hortobágy: Hármas, tőzegpáfrányos lápon [BL, 8492.1]; Mátától É-ra a Rács-fok torkolatánál, a Hortobágy-folyó jobb partján [GG, 8393.3]. Tiszacsege: a Nyugati-főcsatorna 
partjain szórványosan, a Halastói-tápcsatorna és az Árkus-bújtató között [GG, 8392.1, 8392.3]; Újszentmargita: a Nyugati-fő́csatorna partjain szórványosan [GG, 8292.4].

2641. Carex vesicaria L. - Herb.: Siroki (1949): Egyek. Lit.: Soó \& MÁTHÉ (1938): HencidaGáborján. Ined.: BKk: Berettyóújfalu: Füzes [SG, 8795.3]; Somota-dűlő, mocsárfoltban [SG, 8795.1].

2650. Carex secalina Wahlenb. - Herb.: Újvárosi (1935): Hajdúnánás; Siroki (1949): Hortobágy. Lit.: RAPAICS (1916): Hortobágy; MoLNÁR (2005): Tiszaszentimre; Nádudvar; Hajdúszoboszló; Balmazújváros. Ined.: DH: Berettyóújfalu: Nagy-Andaháza, Sárréti-fcst. és a Keleti-fcst. által határolt része [LBA, 8794.2].

2656. Carex distans L. - Herb.: Soó (1932): Egyek, Hajdúbagos; Máthé (1936): Sáránd. Lit.: Soó \& MÁTHÉ (1938): Crisicum-ban közönséges; MolNÁR (2005): Hajdúböszörmény; Tiszaszentimre; Balmazújváros. Ined.: Bs: Ártánd: Drága-oldal [SG, 8896.2].

2666. Epipactis tallosii A. Molnár et Robatsch - Herb.: Molnár V. et al. (2011): Újtikos; Lovas-Kiss \& Takács (2012): Konyári Sóstófürdő; Löki et al. (2013): Hajdúböszörmény. Lit.: MoLnÁR (2005): Hajdúszoboszló; Hajdúnánás; Újtikos; Tiszaderzs; Balmazújváros. Ined.: Bs: Mezốpeterd: Kréta, ültetett erdőben [GG, 8895.2].

2676. Cephalanthera damasonium (Mill.) Druce - Herb.: Molnár V. \& Takács (2014): Hajdúböszörmény (Pród). Lit.: Soó \& MátHÉ (1938): Kisújszállás; MolnÁR (2005): Tiszaderzs; Balmazújváros; TAKÁcs et al. (2014b): Hajdúnánás: Elő-háti-dűlö; MoLNÁR et al. (2017): Kisújszállás: Nagy-erdő. Ined.: Bs: Kismarja: a Kasza-parttól D-re, ültetett kocsányos tölgyes foltban [GG, 8797.1].

2677. Cephalanthera longifolia (L.) Fritsch. - Herb.: Lukács \& Gulyás (2005): Folyás; Takács (2012): Hajdúnánás. Lit.: MoLNÁR (2005): Hajdúnánás; Újtikos; Hajdúszoboszló; Hajdúböszörmény; TAKÁCS et al. (2014b): Folyás-Görbeháza-Hajdúnánás térségéből. Ined.: Bs: Biharkeresztes: Körmező-dűlő, a régi Új Élet Tsz erdősávjában [SG, 8896.3]. Ho: Balmazújváros: Darassai-erdő [LBA, 8393.1]. NS: Biharnagybajom: Korhány [SG, 8793.4]. SzTs: Karcag: Apavára, a Sándorok-D (3. sz.) mellékcsatorna közelében [SA, 8792.1].

2700. Orchis morio L. - Herb.: Kovács (1932): Hencida; Máthé (1938): Hencida. Lit.: Soó (1932): Egyek (Ohati erdő); ÚJvÁRosi (1937): Hajdúnánás; Soó \& MÁtHÉ (1938): Kisújszállás; TALLós \& TóTH (1968): Újszentmargita; MoLNÁr (2005): Polgár, Hortobágy. Ined.: BKk: Kismarja: a G60-G63 határkövek között [GG, 8797.1]; egykori anyagnyerőben, a lokalizációs töltés mellett [GG, 8797.3]; Óriás-part [GG, 8796.2]; Pocsaj: Csonta [GG, 8796.2, 8797.1]; Dobogó [GG, 8797.1]; Három-ágú [GG, 8797.1]; Három-ágú, az országhatár közelében [GG, 8797.1]; Kasza-puszta [GG, 8797.1]; a Kasza-parttól D-re, nagy kiterjedésű legelőn-kaszálón [GG, 8797.1]. Bs: Esztár: Mogyorós, legelőn [GG, 8796.2]; Nyomás-csere, az Esztár-Nagymarjai-mellékcsatorna közelében [GG, 8796.2]; Hencida: Füzes-gát [GG, 8796.3]; Nagy-terebed [GG, 8796.3]; Kismarja: Berettyó jobbparti gyepen, a Fekete-tanya és az országhatár között [GG, 8797.1]; Bor-sziget, a dűlő DK-i részén [GG, 8797.1]; Egresi-kút környéki gyepek, a volt Rákóczi Tsz. mellett [GG, 8797.1]; Fóka-part [GG, 8797.3]; Füzes-gát [GG, 8796.1]; Középső-szik [GG, 8796.2]; Lápis-tó [GG, 8796.4]; Nagymarjai-dűlő [GG, 8796.4]; Vakaró-dűlő [GG, 8796.4]; a Kasza-parttól D-re, nagy kiterjedésủ legelőn-kaszálón [GG, 8797.1]; a lokalizációs töltésen [GG, 8797.1]; a pocsaji Csonta és a Fekete-tanya között, a Berettyó mentén húzódó fajgazdag sztyepréteken [GG, 8796.2, 8797.1]; az EsztárNagymarjai-mellékcsatorna D-i oldalán, fajgazdag maradvány gyepekben [GG, 8796.2]; az országhatáron, a G58-G59 határköveknél [GG, 8797.1]; az országhatáron, a G59-G60 határköveknél [GG, 8797.1]. 


\section{Köszönetnyilvánítás}

Köszönetünket fejezzük ki mindazoknak (Boruzs András, Besenyei László, Deák Balázs, Gebei Lóránt, Kiss Ádám, Mizsei Edvárd, Mesterházy Attila, Molnár V. Attila, Nagy Tímea, Sándor István, Tihanyi Gábor, Tar János, Török Péter, Valkó Orsolya, Ványi Róbert) akik az adataikat rendelkezésünkre bocsátották, vagy részt vettek a terepmunkában. Köszönjük továbbá Somlyay Lajosnak (MTM Növénytár) és Farkas Sándornak (Paks) az irodalmi és herbáriumi adatok keresésében nyújtott segítségüket.

\section{Irodalomjegyzék}

BAGI I. \& SzÉKely Á. (2006): Az Elymus elongatus (Host) Runemark, magas tarackbúza előfordulása a Kiskunság déli részén - a korábbi lelőhelyek rövid áttekintése. - Botanikai Közlemények 93: 77-92.

BÁRÁNY L. (1926): Stratiotes aloides előfordulása a Tisza mentén. - Természettudományi Közlöny 58: 141.

Bartha D., Király G., Schmidt D., Tiborcz V., Barina Z., Csiky J., JakAB G., Lesku B., SchmotZer A., Vidéki R., Vojткó A. \& ZólYomi Sz. (szerk.) (2015): Magyarország edényes növényfajainak elterjedési atlasza. Nyugat Magyarországi Egyetem Kiadó, Sopron, 329 pp.

Bartha D., Molnár V. A. \& Pfeiffer N. (2000): Új adventív növény [Monochoria korsakowii Regel et Maack (Pontederiaceae)] Magyarországon. - Kitaibelia 5: 83-86.

BoDRoGKÖzY Gy. (1965): Ecology of the halophytic vegetation of the Pannonicum II. Correlation between alkali („szik") plant communities and genetic soil classification in the northern Hortobágy. - Acta Botanica Academiae Scientiarum Hungaricae 11: 1-51.

BorBÁs V. (1881): Békésvármegye flórája. - Értekezések a természettudományok köréből. Magyar Tudományos Akadémia. XI. kötet. XVIII. szám. 105 pp.

Borbás V. (1891): Közlemények Békés- és Bihar-vármegyék flórájából. - A magyar orvosok és természetvizsgálók 1890. augusztus 16-20-ig Nagyváradon tartott XXV. vándorgyúlésének történeti vázlata és munkálatai, pp. 479-504.

Boros Á. (1927): Az Elatine hungarica és az E. ambigua újabb hazai termőhelyei. - Magyar Botanikai Lapok 25: 150-153.

Boros Á. (1938): Florisztikai közlemények II. - Botanikai Közlemények 35: 310-320.

Boros Á. (1960): Rizs-gyom tanulmányok. - Agrobotanika 2: 141-163.

CSAPODY V. (1953): A rizs gyomnövényei. - Annales historico-naturales Musei nationalis hungarici 45 (s.n.4): 35-45.

DeÁK B., Molnár A., GÁL L., LuKÁCs B.A., Tihanyi G. \& TöRöK P. (2008): Rumex pseudonatronatus (Borb.) Murb. új előfordulási adatai a Hortobágyi Nemzeti Park területén. - Flora Pannonica 6: 132.

DEÁK B., TöRöK P., TóthmÉRÉsz B. \& VALKó O. (2015): A hencidai Mondró-halom, a löszgyep-vegetáció őrzője. - Kitaibelia 20: 143-149.

EnDEs M. (1982): Természetvédelmi javaslatok a Nagykunság egyes területeinek védetté nyilvánításához. - Tiszafüred. Kézirat, 67 oldal + melléklet.

GôRi Sz., LaKatos Gy., Aradi Cs., K. Kiss M. \& Bitskey K. (1998): A Meggyes-mocsár vegetációja a természetvédelmi rehabilitáció kezdeti fázisán. - Kitaibelia 3: 103-104.

GuLYÁs G. (2013): A kunsági bükköny (Vicia biennis L.) előfordulása Püspökladány mellett. - Kitaibelia 18: 178.

HAZSLINSZKY (1872): Magyarhon edényes növényeinek füvészeti kézikönyve. - Athenaeum, Pest, 504 pp. IGMÁNDY J. (1933): Újabb adatok Hajdú vármegye növényzetéhez. - Debreceni Szemle 7: 340

JAKAB G. \& MoLNÁR V. A. (2005): A Montia linearis (Dougl.) Greene Magyarországon. - Kitaibelia 10: 121-127.

JАКАВ G. \& TóTH T. (2003): Adatok a Dél-Tiszántúl flórájának ismeretéhez. - Kitaibelia 8: 89-98.

JАКАВ G. (2005): Adatok a Dél-Tiszántúl flórájának ismeretéhez II. - Flora Pannonica 3: 91-119.

JAKAB G., RöFlER J., SzABÓ I. \& TóH T. (2000): Florisztikai adatok a Körös-Maros Nemzeti Park illetékességi területéről. - Crisicum 3: 37-41.

JANKA V. (1863): Bemerkungen über das Vorkommen für Ungarn interessanter oder neuer Pflanzenarten. - Oesterreichische Botanische Zeitschrift 13: 113-116.

JANKA V. (1864): Correspondenz. - Oesterreichische Botanische Zeitschrift 14: 354-355.

JANKA V. (1865): Correspondenz. - Oesterreichische Botanische Zeitschrift 15: 197-199. 
JANKA V. (1866): Neue standorte ungarischer Pflanzen. - Österreichische Botanische Zeitschrift 16: 169-172.

JávorKa S. (1934): Kitaibel herbáriuma (Herbarium Kitaibelianum) III. - Annales Musei Nationalis Hungarica 28: 147-196.

Jávorka S. (1935): Kitaibel herbáriuma (Herbarium Kitaibelianum) IV. - Annales Musei Nationalis Hungarici 29: 55-102.

JÁVORKa S. (1936): Kitaibel herbáriuma (Herbarium Kitaibelianum) V. - Annales Musei Nationalis Hungarici 30: 7-118.

KANITZ Â. (1863): Reliquiae Kitaibelianae III., IV. - Zoologisch-Botanische Gesellschaft 13: 57-118.

KAPOCSI J., DomÁn E., BíRó I., ForGÁch B. \& TóTH T. (1998): Florisztikai adatok a Körös-Maros Nemzeti Park müködési területéről. - Crisicum 1: 75-83.

KERNER A. (1867): Die Vegetations-Verhaltnisse des mittleren und östlichen Ungarns und angrenzenden Siebenbürgens VI. - Oesterreichische Botanische Zeitschrift 17: 383-389.

KERNER A. (1868): Die Vegetations-Verhaltnisse des mittleren und östlichen Ungarns und angrenzenden Siebenbürgens XVII. - Oesterreichische Botanische Zeitschrift 18: 343-352.

KERNER A. (1869): Die Vegetations-Verhaltnisse des mittleren und östlichen Ungarns und angrenzenden Siebenbürgens XXIII. - Oesterreichische Botanische Zeitschrift 19: 137-143.

KERNER A. (1873): Die Vegetations-Verhältnisse des mitteleren und östlichen Ungarns und angrenzenden Siebenbürgens LVIII. - Oesterreichische botanische Zeitschrift 23: 54-60.

KERNER A. (1874): Die Vegetations-Verhaltnisse des mittleren und östlichen Ungarns und angrenzenden Siebenbürgens LXVI. - Oesterreichische Botanische Zeitschrift 24: 45-49.

KERNER A. (1875): Die Vegetations-Verhaltnisse des mittleren und östlichen Ungarns und angrenzenden Siebenbürgens LXXVII. - Oesterreichische Botanische Zeitschrift 25: 194-199.

KERNER A. (1877): Die Vegetations-Verhaltnisse des mittleren und östlichen Ungarns und angrenzenden Siebenbürgens LXXXXI. - Oesterreichische Botanische Zeitschrift. 27: 129-134.

KERTÉSz É. (2000): Adatok a Dél-Tiszántúl flórájához. - A Békés Megyei Múzeumok Közleményei 21: 5-48.

Kevey B. \& Pozsony K. (2003): A Digitalis lanata Ehrh. magyarországi elterjedése. - Kitaibelia 8: 117-131.

KIRÁLY G. (szerk.) (2009): Új magyar füvészkönyv. Magyarország hajtásos növényei. Határozókulcsok. Aggteleki Nemzeti Park Igazgatóság, Jósvafő, 616 pp.

Kitaibel P. \& WaldSTein F. (1802): Descriptiones et icones plantarum rariorum Hungariae. Vol. 1., Viennae [1799-]1802-1812. Matthias Andreas Schmidt, tab45.

LANDOLT E. (1975): Morphological differentiation and geographical distribution of the Lemna gibbaLemna minor group. - Aquatic Botany 1: 345-363.

LENDVAI G. (1999): Amygdalus nana L. - In: FARKAS S. (szerk.), Magyarország védett növényei. Mezőgazda Kiadó, Budapest, 102-103.

LESKU B. \& MolNÁR A. (2007): A Hortobágy növényritkaságai. - Hortobágyi Nemzeti Park Igazgatóság, Debrecen, 120 pp.

MAGYAR P. (1928): Adatok a Hortobágy növényszociológiai és geobotanikai viszonyaihoz. - Erdészeti Kísérletek 30: 26-63.

MAJLÁTH I. (2008): Adatok két adventív növényfaj (Zizania aquatica L. 1753, Monochoria korsakowii Regel et Maack 1861) hazai elterjedéséhez. - Kitaibelia 13: 175.

MAROSI S. \& SOMOGYI S. (szerk.) (1990): Magyarország kistájainak katasztere I-II. - MTA FKI, Budapest, 1026 pp.

MÁTHÉ I. (1939): A hencidai „Cserje-erdő” vegetációja. - Botanikai Közlemények 36: 120-129.

MÁTHÉ I. (1932): Adatok Hajdú megye flórájához. - Botanikai Közlemények 29: 87-88.

MÁTHÉ I. (1933): A hortobágyi Ohat-erdő vegetációja. - Botanikai Közlemények 30: 163-184.

MÁTHÉ I. (1936): Növényszociológiai tanulmányok a körösvidéki liget- és szíkes erdőkben. - Acta Geobotanica Hungarica 1: 150-166.

MÁTHÉ I., NAGY L. \& Szócs Z. (1974): Fenológiai és időjárási észlelések az újszentmargitai IBP mintaterületen. - MTA Biol. Oszt. Közlem. 17: 431-447.

Máthé I., TAllós P. \& Zólyomi B. (1967): Peucedano-Galatelletum punctati. - In: Zólyomi B. (szerk.), Guide der Excursionen des Internationalen Geobotanischen Symposiums. Eger-Vácrátót, pp. 62-63.

MESTERHÁZY A., JAKAB G., LuKÁCS B.A., KIRÁLY G. \& VIDÉKI R. (2008): Új Lemna-fajok Magyarországról. Kitaibelia 13: 117.

Mesterházy A., Király G., VidÉKI R. \& LuKÁcs B.A. (2007). A Lemna minuta Kunth előfordulása Magyarországon. - Flora Pannonica 5: 167-174.

Mile O. \& WAlter J. (2003): A Suaeda Forskal ex Scop (Chenopodiaceae) nemzetség Magyarországon. Flora Pannonica 1: 29-43. 
MoEsz G. (1908): Magyarország Elatine-i. - Magyar Botanikai Lapok 7: 2-35.

MolnÁR Zs. (1995): Ártéri vegetáció Tiszadob és Kesznyéten környékén I. Tájtörténeti, florisztikai és cönológiai értékelés. - Botanikai közlemények 83: 39-49.

Molnár A. (1996): A magas tarackbúza (Agropyron elongatum) a Hortobágyon. - In: Tóth A. (szerk.), Ohattól Meggyesig. A Hortobágyi Természetvédelmi Kutatótábor huszonkét éve. Természet- és Környezetvédő Tanárok Egyesülete, Budapest, pp. 116-122.

MolnÁr A. (2005): Adatok a Hortobágy flórájának ismeretéhez. - In: Molnár A. (szerk.), Hortobágyi mozaikok. Hortobágyi Nemzeti Park Igazgatóság, Debrecen, pp. 41-71.

MolnÁr A. (2013): Mételyfú. - In: SAlLAI R. B. (szerk.), Veszélyeztetett Natura 2000-es fajok egyesületi fajvédelmi tervei. Nimfea Természetvédelmi Egyesület, pp. 7-24.

Molnár Cs., Lengyel A., MolnÁr V. A., NAgY T., CSÁBi M., SÜvegES K., LengGyel-Vaskor D., Tóth Gy. \& TaKÁcs A. (2016): Pótlások Magyarország edényes növényfajainak elterjedési atlaszához II. - Kitaibelia 21: 227-252.

MolnÁr Cs., Haszonits Gy., MalatinszkY Á., KovÁCS G.K., KovÁcs G., NagY T., MolnÁr V., A., TAKÁCS A. (2017): Pótlások Magyarország edényes növényfajainak elterjedési atlaszához III. - Kitaibelia 22: 122-146.

MolNÁR V. A. \& GulYÁs G. (2001): Adatok a hazai Nanocyperion-fajok ismeretéhez VII. Az iszapnövényzet fajainak térképezése az Alföldön 2000-ben. - Kitaibelia 6: 169-198.

MolnÁr V. A. \& PFEIFFER N. (1999): Adatok hazai Nanocyperion-fajok ismeretéhez II. Iszapnövényzetkutatás az ár- és belvizek évében Magyarországon. - Kitaibelia 4: 391-421.

MolnÁr V. A., MolnáR A., VIDÉKI R. \& PfEIFFER N. (1999): Adatok hazai Nanocyperion-fajok ismeretéhez I. Elatine hungarica Moesz. - Kitaibelia 4: 83-94.

Molnár V. A., MolnÁr A., VidéKI R., Pfeiffer N. \& Gulyás G. (2000a): Néhány adat Magyarország flórájának ismeretéhez. - Kitaibelia 5: 297-303.

MolnÁr V. A., Pfeiffer N. \& Ristow M. (2000b): Adatok hazai Nanocyperion-fajok ismeretéhez IV. A Lindernia dubia (L.) Pennel [Scrophulariaceae] Magyarországon. - Kitaibelia 5: 279-287.

NikLFELD H. (1971): Bericht über die Kartierung der Flora Mitteleuropas. - Taxon 20: 545-571.

NóTÁRI K., JAKAB G., CSÖRGEI B. \& CSENGERI E. (2011): A Szarvas-1 energiafü (Elymus Elongatus subsp. Ponticus 'Szarvasi-1' energiafü) inváziója Szarvas környékén. - In: LaKaTos F. \& SzABó Z. (szerk.), Nyugat-magyarországi Egyetem, Erdőmérnöki Kar, Kari Tudományos Konferencia Kiadvány. NymE Kiadó Sopron, p. 315.

PENKSZA K. \& KAPOCSI J. (1998): A Maros völgy edényes növényei I. - Crisicum 1: 35-74.

PignATTI S. (1982): Flora d'Italia III. - Edagricole, Bologna, 780 pp.

RAPAICS R. (1916): Debrecen flórája. - Erdészeti Kísérletek 18: 28-80.

RAPAICS R. (1927) A Közép-Tisza vidéki szikes talajok növényszövetkezetei - Debreceni Szemle 1: 104-119.

SCHMOTZER A. (2015): Occurrence of Lindernia dubia in the Ipoly valley (Hungary and Slovakia). - Studia Botanica Hungarica 46: 77-89.

SEREGÉLYES T. (1999): Marsilea quadrifolia L. - In: FARKAS S. (szerk.), Magyarország védett növényei. Mezőgazda Kiadó, Budapest, 102-103.

Simкоvics L. (1878): Új növények leírásai. - Természetrajzi Füzetek 2: 143-148.

Simonkai L. (1873): Adatok Magyarhon edényes növényeihez. - Mathematikai és Természettudományi Közlemények 11: 157-211.

SimonKaI L. (1881): Nagyvárad és a Sebes-Körös felsőbb vidéke. - Mathematikai és Természettudományi Közlemények 16: 71-150.

SimonKAi L. (1890): Nagyváradnak és vidékének növényvilága. - In: BunYiTAY V. (szerk.), Nagyvárad természetrajza. Budapest, Franklin Társulat Nyomdája, pp. 47-137.

SOMLYAy L. \& BAUER N. (2013): Adatok a Vicia biennis L. elterjedéséhez a Pannonicum-ban. - Kitaibelia 18: $125-128$.

SomLYAy L. (2009): Agrostis L. - In: KiRÁLY G. (szerk.), Új magyar füvészkönyv. Magyarország hajtásos növényei. Határozókulcsok. Aggteleki Nemzeti Park Igazgatóság, Jósvafö, p. 529.

Soó R. \& MÁTHÉ I. (1938): A Tiszántúl flórája. - Magyar flóraművek II. A Debreceni Egyetem Növénytani Intézetének kiadása, Debrecen, 192 pp.

Soó R. (1925): Aster-tanulmányok. - Botanikai Közlemények 22: 56-64.

Soó R. (1932): Újabb adatok Hajdú megye flórájához. - Botanikai Közlemények 29: 86-87.

Soó R. (1934a): A Magyar vizek virágos vegetációjának rendszertani és szociológiai áttekintése II. Magyar Biológiai Kutatóintézet Munkái 7: 135-153.

Soó R. (1934b): A Hortobágy növénytakarója. (A szíkespuszta növényszövetkezeteinek ökológiaiszociológiai jellemzése.) - Debreceni Szemle 8: 56-77. 
Soó R. (1934c): Nyírség-kutatásunk florisztikai eredményei. - Botanikai Közlemények 31: 218-252.

Soó R. (1937): Pótlékok Nyírségi flórakutatásunk eredményeihez. - Botanikai Közlemények 34: 33-44.

Soó R. (1938): A Magyar vizek virágos vegetációjának rendszertani és szociológiai áttekintése. Magyar Biológiai Kutatóintézet Munkái 10: 174-194.

Soó R (1940): Hajdúszoboszló virágos növényei. (Pótlások Soó-Máthé Tiszántúl flórájához II.) Debreceni Szemle 14: 161-164.

Soó R. (1948): Tiszántúl flórakutatásának újabb eredményei. (Pótlások Soó-Máthé Tiszántúl flórájához V.) - Borbásia 8: 48-57.

Soó R. (1968): A magyar flóra és vegetáció rendszertani és növényföldrajzi kézikönyve III. - Akadémiai Kiadó, Budapest, p. 37.

Soó R., FELFÖLDY L. \& IGMÁNDY J. (1942): Pótlékok nyírségi és tiszántúli flórakutatásunk eredményeihez III. - Botanikai Közlemények 39: 45-56.

STEFFEK A. (1864): Uebersicht der bei Grosswardein bis jetzt beobachteten Phanerogamen. Oesterreichische Botanische Zeitschrift 14: 169-187.

ŠTĔPANKOVA J. (1995): Myosotis sicula new to Hungary. - Preslia 66: 255-259.

SzABó L., HoRváth Zs. \& Pintér I. (1973): A természetes flóra géntartalékai Magyarországon. Agrobotanika 15: 57-81.

SzujKó-LacZa J., Fekete G., Kováts D., Szabó L. \& Siroki Z. (1982): The vascular plants of the Hortobágy National Park. - In: SzujKó-LACZA J. (ed.), The Flora of the Hortobágy National Park. Akadémiai Kiadó, Budapest, pp. 105-169.

TÁBorská J., VojTKó A., Dulai S. \& Schmotzer A. (2015): Distribution of Aegilops cylindrica Host in Hungary. - Thaiszia 25: 41-72.

TAKÁCS A. \& Zsólyomi T. (2010): Adatok a Taktaköz flórájának ismeretéhez. - Kitaibelia 15: 25-34.

TAKÁCS A., NAGY T., FEKETE R., LovAs-Kiss Á., LJUBKA T., LÖKI V., LisZTES-SZABÓ Zs. \& MolnÁR V. A. (2014a): A Debreceni Egyetem Herbáriuma (DE) I.: A „Soó Rezső Herbárium”. - Kitaibelia 19: 145-155. + elektronikus melléklet.

TAKÁcs A., Nagy T., SRAmkó G., Lovas-Kiss Á., Süveges K., LukÁcs B. A., FeKETE R., LÖKi V., Malatinszky Á., E. Vojtkó A., Koscsó J., Pfliegler W. P., Nótári K. \& Molnár V. A. (2016): Pótlások a Magyarország edényes növényfajainak elterjedési atlaszához I. - Kitaibelia 21: 101-115.

TAKÁCS A., SCHMOTZER A. \& SULYOK J. (2013): Florisztikai adatok a Sajó-Hernád-sík területéről. - Kitaibelia 18: 73-88.

TakÁcs A., Süveges K., Ljubka T., LöKi V., LiszTes-Szabó Zs. \& Molnár V. A. (2015): A Debreceni Egyetem Herbáriuma (DE) II.: A „Siroki Zoltán Herbárium”. - Kitaibelia 20: 15-22. + elektronikus melléklet.

TAKÁCS A., ZÁKÁNY A., GulYÁs G., Koscsó J. \& SRAMKó G. (2014b): Florisztikai adatok a Tiszántúl északi pereméről. - Kitaibelia 19: 275-294.

TAllós P. \& TótH B. (1968): Az újszentmagitai sziki reliktum erdő termőhelyi adottságai, növénytársulásai és kapcsolatuk a fatermesztési lehetőségekkel. Kísérletügyi Közlemények LXI/D. Erdőgazdaság és Faipar 1-3: 75-107.

TAMÁssy G. (1927): Hajdu vármegye és Debrecen sz. kir. város növényzete. - Debreczeni Ujság nyomdája, 71 pp.

TAMÁssy G. (1931): Florisztikai közlemények II. - Botanikai Közlemények 28: 87-88.

THAISZ L. (1907): Additamenta nova Florae Hungaricae. - Magyar Botanikai Lapok 6: 166-169.

Tóтн T. (2003): Újabb adatok a Dél-Tiszántúl flórájának ismeretéhez. - A Puszta 20: 135-170.

Tuzson J. (1915): A Magyar Alföld Növényföldrajzi tagolódása. - Math. Term. Tud. Ért. 143-220.

Tuzson J. (1920): A püspökladányi vallási alapítványi uradalom egyes részeinek befásítása. - Erdészeti Lapok 59: 516-522.

UBRIZSY G. (1949): Adatok a Tiszántúl (Crisicum) flórájának ismeretéhez, különös tekintettel Szarvas és környékére - Borbásia 9: 7-15.

UBRIZSY G. (1961): Unkrautvegetation der Reiskulturen in Ungarn. - Acta Bot. Acad. Sci. Hung. 7: 175-220.

UjVÁrosi M. (1937): Hajdúnánás vegetációja és flórája. - Acta Geobotanica Hungarica 1: 169-214.

Ujvárosı M. (1940): Pótlások Soó-Máthé "Tiszántúl flórájá"-hoz. - Debreceni Szemle 14: 107.

UjVÁrosı M. (1941): Adatok a borsodi sík flórájához Budai József gyűjtéséből (Pótlások Soó-Máthé: Tiszántúl flórájához III.). - Debreceni Szemle 15: 6-10.

Ujvárossy M. (1936): Adatok a Tiszamente és Hajdúnánás flórájához. - Debreceni Szemle 10: 60-61.

ZsÁK Z. (1941): Florisztikai adatok a hazai növényvilág ismeretéhez. - Botanikai Közlemények 38: 12-34. 